Научный совет РАН по исторической демографии и исторической географии Институт языка, литературы и истории Коми НЦ УрО РАН

Институт российской истории РАН

Институт истории и археологии УрО РАН

Отделение Российского исторического общества в Республике Коми

\title{
ИСТОРИЧЕСКАЯ ДЕМОГРАФИЯ
}

\author{
Научный журнал
}

№ 1 (27) 
ISSN 2304-5922

УДК 314.148

ИСТОРИЧЕСКАЯ ДЕМОГРАФИЯ. Научный журнал. 2021. № 1 (27).

Основан в 2008 г.

Выходит 2 раза в год

Учредитель - Институт языка, литературы и истории Коми научного центра УрО РАН Журнал издается под руководством Научного совета РАН по исторической демографии и исторической географии

\section{Редакичионная коллегия:}

И.Л. Жеребцов (главный редактор, Сыктывкар), В.Б. Жиромская (зам. главного редактора, Москва), В.А. Исупов (зам. главного редактора, Санкт-Петербург), В.В. Фаузер (зам. главного редактора, Сыктывкар), Н.М. Игнатова (отв. секретарь, Сыктывкар), Ю.В. Аргудяева (Владивосток), А.Е. Загребин (Ижевск), Г.Е. Корнилов (Екатеринбург), Е.Ф. Кринко (Ростов-на-Дону), С. Лаллукка (Хельсинки), В.И. Меньковский (Минск), С.А. Прокопенко (Ульяновск), И.А. Разумова (Апатиты), Т.С. Садыков (Нур-Султан), М.С. Черкасова (Вологда), М. Шмигель (Банска-Быстрица)

\section{Редакиионно-издательская группа:}

Н.М. Игнатова (руководитель, Сыктывкар), Д.В. Вишнякова (Сыктывкар), Н.К. Забоева (Сыктывкар), С.А. Попов (Сыктывкар)

Адрес редакции: 167982, г. Сыктывкар, ул. Коммунистическая, 26, ИЯЛИ Коми НЦ УрО РАН, журнал «Историческая демография».

Тел. (8212)245564 (гл. ред.), факс (8212)245564

E-mail: zherebtsov@mail.illhkomisc.ru (гл. редактор), ignatova.hist@mail.komisc.ru (отв. секретарь, рук. редакционно-издательской группы) 


\section{СОДЕРЖАНИЕ}

\section{ЭТНОДЕМОГРАФИЧЕСКОЕ РАЗВИТИЕ СТРАН И РЕГИОНОВ В ИСТОРИЧЕСКОЙ РЕТРОСПЕКТИВЕ}

Аверьянов К.А. (Москва). Куликовская битва: демографические потери Руси DOI: $10.19110 / 2304-5922-2021-1-4-10$

Вишнякова Д.В. (Сыктывкар). Смертность населения Коми края в конце XIX - начале XX в.: возрастной состав умерших DOI: $10.19110 / 2304-5922-2021-1-11-14$

Макаренко М.Ю. (Краснодар). Состав и структура населения Северного Кавказа по материалам переписи 1926 г. DOI: $10.19110 / 2304-5922-2021-1-15-20$

Игнатова Н.М. (Сыктывкар). Воспроизводство населения у спецпереселенцев Европейского Севера в 1930-е гг.: кризис и адаптация 21 DOI: $10.19110 / 2304-5922-2021-1-21-27$

Обедков А.П. (Сыктывкар). Сдвиги в размещении и тенденции расселения населения Республики Коми в 1920-2020 гг. .28 DOI: $10.19110 / 2304-5922-2021-1-28-45$

\section{ИСТОРИОГРАФИЯ, ИСТОЧНИКИ, МЕТОДОЛОГИЯ}

Силин В.И. (Сыктывкар). Хозяйство Архангельской губернии и поселения на Печоре и Ижме по данным старых карт .46 DOI: $10.19110 / 2304-5922-2021-1-46-49$

Tеребихин B.M. (Сыктывкар). Антропологический кризис как интегральная оценка демосоциального развития Республики Коми в период социетальной трансформации (ревореформ) 1991-1995 гг. DOI: $10.19110 / 2304-5922-2021-1-50-56$

\section{НАУЧНОЕ НАСЛЕДИЕ}

Лашук Л.П., Жеребцов Л.Н. (Сыктывкар). Отчет Прилузской этнографической экспедиции 1959 г. Материалы к этнической истории

РЕЦЕНЗИИ. ХРОНИКА. БИБЛИОГРАФИЯ

Содержание журнала «ИСТОРИЧЕСКАЯ ДЕМОГРАФИЯ» за 2020 год .....................................

ПРАВИЛА ДЛЯ АВТОРОВ журнала «Историческая демография» 


\section{ЭТНОДЕМОГРАФИЧЕСКОЕ РАЗВИТИЕ СТРАН И РЕГИОНОВ В ИСТОРИЧЕСКОЙ РЕТРОСПЕКТИВЕ}

\section{К.A. Аверьянов*}

\section{Куликовская битва: демографические потери Руси}

Несмотря на то, что исторические источники дают точные сведения о числе погибших русских воинов на Куликовом поле (250 тыс. чел.), большинство исследователей полагают их преувеличенными, а сражение считают незначительным событием. В качестве аргумента приводится мнение, что на Куликовом поле не было физической возможности поместить огромную массу людей. Анализ всей совокупности материалов показывает правоту источников. Выясняется, что битва происходила примерно в 50 км от общепринятого места, в верховьях реки Непрядвы. Здесь же обнаруживаются захоронения погибших воинов.

Ключевые слова: Куликово поле, Дмитрий Донской, численность войск, демографические потери, захоронения

\section{K.A. Averjanov}

\section{The Kulikovo field: demographic losses of Russia}

Despite the fact that historical sources provide accurate information about the number of Russian soldiers who died on the Kulikovo field (250 thousand people), most researchers consider them to be exaggerated, and the battle was an insignificant event. As an argument, the opinion is given that it was not physically possible to place a huge mass of people on the Kulikovo field. Analysis of the entire set of materials shows the correctness of the sources. It turns out that the battle took place about $50 \mathrm{~km}$ from the generally accepted place, in the upper reaches of the Nepryadva River. The graves of the dead soldiers are also found here.

Key words: Kulikovo field, Dmitry Donskoy, number of troops, demographic losses, burials

Одним из переломных моментов истории России стала Куликовская битва 1380 г., ознаменовавшая объединение русских княжеств в борьбе против ордынского ига. Какова же была демографическая цена этой победы?

Согласно «Сказанию о Мамаевом побоище», подсчеты русских потерь было поручено вести московскому боярину Михаилу Александровичу, который был «росчетлив бысть вельми». Он доложил великому князю: «изгибло у нас дружины всеа полтретья ста тысящ и три тысящи, а осталося у нас дружины пятьдесят тысящ» [1, с. 75]. Поскольку «полтретья»- дробное число, количество чего-либо, равное двум с половиной, получается, что потери составили 253 тыс. чел. из общего числа в 303 тыс. сражавшихся воинов.

Что касается численности армии Мамая, «Сказание» определяет ее в 453 тыс. воинов. Эта цифра в памятнике возникла следующим образом. 23 июля 1380 г. из «Дикого поля» в Москву примчался Андрей Попов сын Семенов, сообщивший великому князю: «Идет на тебя, государь, царь Мамай со всеми силами ордынскими, а ныне на реки на Воронежи, а мы его силу обезжали 12 дний, и подстерегли нас царевы сторожи, мене

\footnotetext{
* Аверьянов Константин Александрович (Москва) - доктор исторических наук, ведущий научный сотрудник Центра изучения истории территории и населения России Института российской истории PAH, histgeogr@yandex.ru.
} 
и поимали». Далее он рассказал, что Мамай самолично сообщил ему о своих силах, составлявших в общей сложности 453 тыс. чел., велел по полкам водить и «показывати сосуды избранныя, еже на взятие руским градом привезли бяше». Русскому разведчику удалось убежать «у самого царя из рук», и он поспешил сообщить эти сведения в Москву [1, с. 169-170].

С учетом этих цифр в 1849 г. преподавателем Кадетского корпуса И.Ф. Афремовым был составлен план Куликовской битвы [2], на протяжении полутора столетий с теми или иными вариациями кочующий из одной работы в другую. На нем силы противников выстроены в несколько линий, своими флангами упирающимися в Непрядву и Дон. При этом ставку Мамая И.Ф. Афремов расположил на Красном холме, самой высокой точке местности, а русский лагерь поместил у села Монастырщино близ слияния Непрядвы с Доном.

Военные историки XIX в., непосредственно побывавшие на месте сражения, заметили странность этой схемы. Между Красным холмом и селом Монастырщино около 10 км по прямой (при том, что линия горизонта видна на расстоянии 11 км). Как известно, биноклей в XIV в. не существовало, а первые подзорные трубы были изобретены лишь в самом начале XVII в. Это абсолютно исключает возможность того, что именно из этих пунктов полководцы руководили сражением. Они должны были находиться гораздо ближе друг к другу. В XIX в. штаб-квартиры противников располагались на более близких расстояниях. Во время Бородинского сражения ставка Кутузова находилась в деревне Горки, а Наполеона - в деревне Валуевой, расстояние между которыми составляет по прямой всего около 5 км.

Данный факт посеял первые сомнения в истинности хрестоматийного плана Куликовской битвы. По мнению Д.Ф. Масловского (1848-1894), в древности Куликово поле в доступном для полков виде достигало в ширину не более 2,5-3 км при длине (между пригодными для наблюдения возвышенностями) около 4 км [3, с. 212].

Все это привело к тому, что к середине XX в. возобладала точка зрения, что настоящая картина сражения сильно отличалась от хрестоматийной, когда развернувшийся на Куликовом поле бой представляли как столкновение огромных людских масс, расположенных по фронту длиной 5-5,5 и даже 10 км [4; 5; 6; 7; 8].

Первой жертвой недоверия стала указанная в «Сказании» численность сражавшихся. Историки посчитали ее крайне завышенной, хотя бы потому, что подобные цифры характерны для войн более поздних эпох. Так, в 1812 г. Наполеон, располагавший 685 тыс. чел. для войны с Россией, переправил через границу 420 тыс. чел. Ему противостояли русские армии в 225 тыс. чел. Сомнения вызвали и данные «Сказания» о русских потерях. При том что в ХІХ в. в генеральных сражениях люди в своей массе гибли от массированного артиллерийского огня, потери были гораздо меньше. Полагают, что в Бородинской битве русские потеряли от 45 до 50 тыс. чел. из общей численности в 150 тыс. солдат. Добавим, что в XIV в. артиллерия только зарождалась и на Куликовом поле не использовалась.

Первым детальную попытку определить численность русского войска на основании независимых источников предпринял военный историк Е.А. Разин (1898-1964). Он предложил использовать данные о количестве населения за XVI в., с поправкой в меньшую сторону для XIV в. Подсчитано, что в границах того времени, исключая Сибирь, имелось 220 городов. Если предположить, что в 50 городах насчитывалось по 3 тыс., а в остальных по 1 тыс. жителей, то получится, что во всех городах жило примерно 340 тыс. чел. Сельское население на тот момент, по сведениям Н.Д. Чечулина (1863-1927), составляло около 1100 тыс. жителей.

Следовательно, в XVI в. на всей территории Русского государства в границах того времени насчитывалось примерно 1440 тыс. жителей, из которых мужчин от 15 лет и старше - 435 тыс. Духовенство и монахи составляли не менее $10 \%$, старики свыше 60 лет - около 5\% (они исключаются из мобилизационных расчетов). Остается всего 360 тыс., из которых вряд ли можно было привлечь в войско свыше 10-15 \%, что составит 36-54 тыс. воинов.

Эти данные относятся к XVI в. В обстановке непрерывных войн XIV в. плотность населения не могла быть высокой, вряд ли более 5 чел. на 1 км², что дает 250-300 тыс. жителей в Московском великом княжестве. При высоком мобилизационном напряжении в 10 \%, что маловероятно по тому времени, могло быть собрано 25-30 тыс. воинов, из которых не менее 5 тыс. чел. было оставлено в Москве в качестве стратегического резерва. Следовательно, в поход выступило 20-25 тыс. воинов. Все другие княжества могли дать 25-30 тыс. воинов. Общая численность русской рати, вероятно, не превышала 50-60 тыс. чел., т. е. была гораздо меньше цифр, имеющихся в летописях.

К тем же выводам можно прийти и при изучении на местности поля сражения. Левый фланг боевого порядка русской рати точно обозначен на местности высотой, на которой была в то время Зеленая дубрава; правый фланг упирался в овраг ручья Нижний Дубяк. Протяжение фронта не превышало 5 км, глубина поля достигала 4 км. 
Если исходить из возможности развертывания главных сил русской рати на 4-5-километровом фронте (три полка) при построении пехоты и конницы глубиной в 10 шеренг (для конницы количество шеренг надо снизить), при наличии интервалов между тактическими и организационными полками, то в главных силах окажется не более 25-30 тыс. чел. В трех остальных полках вряд ли было больше этого. Следовательно, и при таком расчете подходим опять к цифре 50-60 тыс. чел. [9, с. 271-273, 387].

Были предприняты попытки оценить силы Мамая. В.А. Кучкин предложил использовать метод аналогий. Считается, что в 1340 г. хан Узбек для похода на Польшу собрал 40-тысячное войско, очевидно, только с западной части Орды. В походе Тохтамыша на Тебриз в 1384/85 г. участвовало около девяти туманов, т. е. 90 тыс. воинов. Это войско было собрано, скорее всего, с обеих частей Орды [10, с. 391; 11, c. 109]. Учитывая, что в 1380 г. Мамай распоряжался лишь западной половиной Орды, В.А. Кучкин говорил о 40-60-тысячной армии, собранной им для похода на Русь [12, с. 3-21].

К тем же цифрам пришел воронежский историк Ю.В. Селезнев, который вслед за Л.Г. Бескровным (1905-1980) полагал ориентировочную численность золотоордынского войска в 50-60 тыс. воинов [13, c. 6-20.]. По его мнению, примерно таким же потенциалом обладало и Московское княжество, которое могло выставить до 70 тыс. чел., т. е. даже несколько больше, чем сами татары. Говоря о войске Мамая, он обратил внимание на фразу из «Задонщины»: «... пришел на Рускую землю царь Мамай со многими силами, з девятью ордами и 70 князями» [1, с. 18]. Таким образом, Мамаю были подчинены девять улусоворд. Это был собственный улус Мамая - Крым. Далее следовали улусы Мауци, Картана и Сартака, выделенные Батыем своим ближайшим родственникам еще при образовании Орды. Следует упомянуть пограничные с русскими землями улусы с зависимым от Орды населением - Червленый Яр и Мордовский улус. Наконец, Мамай распоряжался тремя улусами на юго-востоке его владений: Северным Кавказом, Дербентом и Астраханью. Каждый улус находился под властью царевича-чингисида или эмира (великого князя), командовавшего в походе туменом («тьмой») - отрядом в 10 тыс. воинов. Следовательно, по подсчетам Ю.В. Селезнева, теоретически Мамай мог выставить до 90 тыс. чел.

Однако со всех девяти подчиненных «орд» Мамаю, на взгляд исследователя, удалось собрать лишь 70 тыс. чел. Эта цифра возникла у него следующим образом: согласно «Задонщине», войсками Мамая командовали 70 князей, а на Руси татарскими князьями называли нойонов или эмиров, которые в походах обычно возглавляли отряды численностью по 1 тыс. воинов. Столь большой недобор, по его мнению, объяснялся усобицами в Орде и гибелью в сражении на Воже в 1378 г. части войска эмира Бегича.

Попытался историк перепроверить эти данные. Он обратил внимание, что в «Сказании» приводится сообщение, что передовые ордынские всадники, столкнувшись с русскими полками накануне битвы, сообщили Мамаю о четырехкратном превосходстве войск Дмитрия Донского над его силами: «Поведаша царю, яко князей русскых въинство четверицею больши нашего събраниа» [1, с. 62]. Поскольку этим же источником размеры русской рати определяются в 303 тыс. чел., получается, что численность ордынцев составляла 77 тыс. воинов. Эта цифра близка к подсчетам демографа Б.Ц. Урланиса (1906-1981), полагавшего, что войско Орды в 1380 г. насчитывало около 60 тыс. чел. [14, с. 38-39; 15, с. 45-51].

Позднее наметилась тенденция еще большего уменьшения сил противников. Поводом для этого стали палеопочвенные, палеоботанические и палеогеографические исследования Куликова поля, проведенные в 1980-х гг. Оказалось, что на месте ныне широкого поля на правобережье Непрядвы в древности располагался лес, постепенно переходивший в лесостепь, имевшую лишь небольшие открытые поляны-«кулиги» шириной 2-3 км. Их наличие не позволяло выстроить войска, как это принято изображать на схемах в учебниках. К тому же на них никак не могло уместиться сколь-нибудь значительное количество ратников [16, с. 60-70].

Неудивительно, что уже в 1982 г. А.Н. Кирпичников (1929-2020) пришел к выводу о преувеличении историками пространства Куликова поля, предназначенного для размещения полков в 2-3 раза. Отметил он и явную несообразность общепринятой схемы, когда полки размещались перед холмами, реками, долинами, а то и на месте вырубленных к ХІХ в. дубрав [17, с. 296-297].

Любопытны расчеты Ф.Ф. Шахмагонова (1923-2014), попытавшегося опровергнуть численные данные памятников Куликовского цикла. В советском школьном учебнике для 7-го класса М.В. Нечкиной и П.С. Лейбенгруба говорилось, что войско Дмитрия Ивановича насчитывало 150 тыс. воинов. По мнению некоторых историков, войско Орды превосходило русское войско в три раза, т. е. численность Мамаева войска приближалась к 500 тыс. воинов.

В современной литературе встречается утверждение, что все Куликово поле занимает площадь около

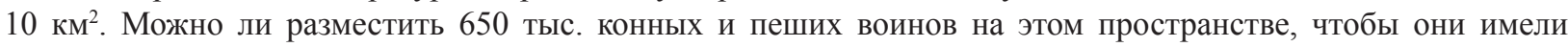
возможность двигаться, действовать, идти в атаку, рубиться, наступать и отступать. Войско Мамая было конным. Всадник для минимального движения, для того чтобы просто стоять в строю, должен занимать 


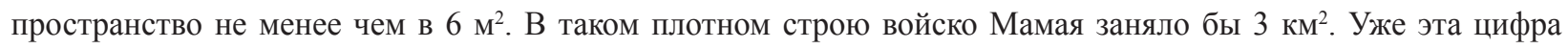
говорит об абсурдности утверждения о численности Мамаева войска в 500 тыс. воинов [18, с. 11-13].

Столь наглядная картина привела А.Е. Петрова к выводу о необходимости решительного отказа от прежней схемы сражения [19, с. 26-30]. В соответствие с этим историки стали резко уменьшать численность русской армии на Куликовом поле. Уже в 1976 г. А.Н. Кирпичников пришел к выводу, что у Дмитрия Донского было примерно 36 тыс. воинов, поскольку стотысячное войско превращается в «неуправляемую толпу людей, только мешающих друг другу». Примерно те же цифры (не более 30 тыс. бойцов или несколько меньше) позднее допустил Ю.В. Селезнев [20, с. 16; 21, с. 29]. Вероятно, такой же была и численность ордынцев. Тем самым получалось, что в битве с двух сторон участвовало приблизительно 60 тыс. чел.

Указанные цифры вполне сопоставимы с оценками числа участников наиболее известных сражений XIV-XV вв. в Западной Европе. В 1346 г. в сражении при Креси с английской стороны принимали участие около 6 тыс. воинов, включая примерно 2,5 тыс. конных латников, которым противостояли 20-25 тыс. французов, в том числе 12 тыс. рыцарей и 6 тыс. наемных арбалетчиков. В 1356 г. в битве при Пуатье против 6-7 тыс. англичан сражались около 11 тыс. французов (8 тыс. конных латников и 3 тыс. пехотинцев). В 1415 г. битва при Азенкуре закончилась победой английской армии численностью 9-9,5 тыс. чел. (в том числе 1,5 тыс. конных латников), разгромившей 12-14 тыс. французов, в составе которых было 8-9 тыс. конных латников [22].

В последние годы обозначилась тенденция к еще большему уменьшению численности русского войска. В.В. Пенской оценил численность русской рати на Куликовом поле в 5-6 тыс. конных воинов. А.А. Булычев пошел еще дальше, предположив, что в русском войске на Куликовом поле было порядка 1-1,5 тыс. конных воинов при общей численности всей рати (вместе с обозной прислугой) около $3-5$ тыс. чел. [23; 24, с. 11-12].

В соответствии с этим стало превалировать мнение, что битва была исключительно конным сражением. По мнению М.И. Гоняного (1953-2020), протяженность места боевых столкновений составляла 2 км при максимальной ширине 800 м. Что касается числа сражающихся, то на взгляд О.В. Двуреченского, следует говорить исключительно о конниках, «от пяти до десяти тысяч как с той, так и с другой стороны» [25]. Больше куликовские поляны вместить просто не могли.

Эти данные хорошо объясняли достаточно малое число найденных археологами на классическом месте битвы остатков вооружений [26]. Кроме того, более понятным становился вопрос о захоронении павших. Сорокалетние поиски могил участников сражения, начавшиеся на Куликовом поле сразу после 600-летнего юбилея в 1980 г., так ничего и не дали. Поэтому в литературе стала превалировать точка зрения, что по оценкам военных историков, в сражениях, подобных Куликовской битве, обычно погибало от 10 до $15 \%$ воинов. Следовательно, в ходе Мамаева побоища могло пасть от 6 до 9 тыс. чел. Их останки могли разместиться в относительно небольшом захоронении площадью примерно 50 кв. м. Благодаря археологическим разведкам известно о существовании древнерусского могильника в районе села Монастырщино. Но планомерные раскопки там невозможны из-за наличия на этой территории сельских домов.

Как видим, в современной литературе возобладала точка зрения о незначительности сил, противостоявших друг другу, тем более что Куликово поле просто не могло физически вместить в себя более или менее значительные силы противников.

Однако данное утверждение входит в противоречие с данными источников. Как известно, через два года после Куликовской битвы на Русь напал хан Тохтамыш. Великий князь Дмитрий решил было сопротивляться, но людские потери на Куликовом поле были настолько велики, что он вынужден был оставить Москву.

Все это заставляет более тщательно рассмотреть аргументы сторонников незначительности сил на Куликовом поле. По подсчетам военных историков призывной потенциал составляет примерно 10 \% от населения страны. Как уже говорилось, Е.А. Разин, опираясь на подсчеты Н.Д. Чечулина, оценивал численность населения России в XVI в. примерно в 1440 тыс. жителей. Но данная цифра является не более чем оценкой. Гораздо большего внимания заслуживают подсчеты, основанные на анализе источников. В частности, А.И. Копанев (1915-1990), опираясь на данные новгородских писцовых книг, пришел к выводу, что в середине XVI в. население России достигло 9-10 млн. чел. При этом за первую половину столетия оно увеличилось в 1,5 раза [27]. С учетом этого можно полагать, что в XIV в. оно должно было составлять не менее 4 млн. чел. При 10 \% призывного потенциала можно говорить о 400 тыс. воинов, которых мог мобилизовать великий князь Дмитрий.

Данная цифра полностью подтверждается «Сказанием о Мамаевом побоище». Забелинский список «Сказания», очень внимательный к цифрам, указывает размеры русского войска, переправившегося через Оку. Великий князь приказал всем князьям и воеводам после переправы «росчести силу ево, кождо под которым воеводою, сколко силы, розочтоша же тогда Рускую землю. Говорит бо тогда 1-й [воевода] князь Федор Семенович: “подо мною силы 25 000”; вторый воевода князь Глеб Брянской: “еодо мною силы $25000 ” ;$ 
третий воевода говорит князь Дмитрей Всеволожской: “подо мною силы 36 000”; четвертый же воевода князь Михайла Васильевичь: “еподо мною силы 20 000”; пятый воевода говорит Тимофей Волуевич: “подо мною силы 15 000"; шестый воевода Иван Родионовичь Квашня: “со мною силы 16 000”; седмой воевода переславский Андрей Серпуховичь: “со мною силы 16 000”; осмой воевода князь Андрей Муромской: “со мною силы 18 000"; девятый воевода Данила Белеутов: “со мною силы 13 000”; десятый воевода Констянтин Конанович: “со мною силы 20 000”; да всей силы с великим князем Дмитрием Ивановичем 400000 без дву тысящ кованой рати. Того же дни приехаша после числа (т. е. исчисления. $-A в m$.$) за Оку$ реку к великому князю посадники новгородцкие Великого Новаграда, а с ними силы пришло 30 000» [1, с. 180-181]. Таким образом, из общего числа ратников в 398 тыс. чел., которых удалось мобилизовать Дмитрию, Оку в конце августа 1380 г. перешли 234 тыс. воинов, включая новгородцев.

Эта же цифра в 400 тыс. мобилизованных встречается в описании Киприановской редакцией «Сказания» эпизода прихода к Березую за три дня до битвы пехоты и обоза: «и ту приидоша много пешаго воиньства, и житестии мнози людие и купци со всех земель и градов». Данное известие явно восходит к очевидцу событий: «И бе видети зело страшно многое множество людей събрашися, грядуще в поле противу татар. И начаша считати, колико их всех есть, и изочтоша вящше четырех сот тысящъ воиньства коннаго и пешего» [28, с. 60]. Важно отметить, что это количество практически точно совпадает с подсчетами Забелинского списка общего числа мобилизованных при переправе через Оку. Зная по подсчетам потерь, что в сражении принимало участие 303 тыс. чел., можно установить, что великий князь оставил в Москве и для охраны коммуникаций около 100 тыс. воинов.

Что касается оценки численности ордынского войска, укажем, что в распоряжении Мамая было отнюдь не «девять орд и 70 князей», как говорится в «Задонщине». Согласно Забелинскому списку «Сказания», темник имел «силы моей 12 орд да три царства, а князей со мною 73, опрочи боловных, сполских 31 князь, а силы моей 453 000» [1, с. 170]. Комментируя данный отрывок, М.Н. Тихомиров писал: «что значит “боловных" неясно, возможно, здесь ошибка вместо “еголовных". Слово “сполских" переводим как естепных"от слова "еполе - степь". Существовало и русское слово “сполие" (всполье), которое И. И. Срезневский переводил как “берег”, а Даль - как "край, окраина, начало поля, выгон”» [1, с. 331].

Разницу в показаниях «Задонщины» и «Сказания о Мамаевом побоище» относительно численности ордынского войска можно объяснить тем, что они относятся к разному времени. Известно, что Мамай стоял на Воронеже три недели. Очевидно, это было вызвано тем, что он ожидал подхода подкреплений. Аналогичную ситуацию видим и в случае с русской стороной. В частности, Пространная «Летописная повесть», говоря о сборе русских войск в Коломне, сообщает: «И съвокупився с всеми князми рускими и с всею силою, и поиде противу их вборзе с Москвы, хотя боронити своея отчины, и прииде на Коломну и събрав вой своих 100 и 50 тысячь опрочно рати княжей и воевод местных» [1, с. 31; 28, с. 17]. В данном случае речь идет о том, что собственные силы Дмитрия составляли 150 тыс. чел.

Говоря об оценке Ю.В. Селезневым русского войска по размерам вчетверо больше татарского, следует упрекнуть исследователя в неучете всей совокупности источников. Действительно, в Основной и Летописной редакциях «Сказания» читаем: «Поведаша царю, яко князей русскых въинство четверицею больши нашего събраниа». Остается, правда, непонятным - каким образом они смогли так точно оценить силу противника. Ясность наступает, если прочитать данный сюжет по Распространенной редакции, содержащей неискаженный переписчиками текст: «много людей видеша, с четверицею того сказаша царю множество людей видеша». Тем самым выясняется, что известие о приходе русских оказалось для Мамая полной неожиданностью, и он поверил в него только после того, как это подтвердил не один, а четверо воинов [1, с. 16, 62, 95, 140-141, 187].

Как видим, показания «Сказания о Мамаевом побоище», несмотря на то, что оно было создано спустя столетие после битвы, следует признать достоверными.

Но могла ли такая огромная масса людей разместиться близ впадения Непрядвы в Дон? Как уже говорилось, в XIV в. это была местность с относительно небольшими открытыми полянами. Между тем летописи, описывая место битвы, дружно подчеркивают наличие огромного открытого пространства. Софийская первая и Новгородская четвертая летописи сообщают, что «великии же князь Дмитрии Иванович перешед в поле чисто в ордынскыя земли, на усть Непрядвы рекы» [29, т. VI, вып. 1, стб. 463; т. IV, ч. 1 с. 318 ]. Это подтверждают Новгородская первая летопись: «Въниде бо в землю их за Дон и бе ту поле чисто, на усть рекы Непрядвы» [29, т. III, с. 376], Симеоновская летопись и Рогожский летописец: «Князь же великии поиде за Донъ, и бысть поле чисто и велико зело, и ту сретошася погани половци, татарскыи полци, бе бо поле чисто на усть Непрядьвы реки» [29, т. XVIII, с. 129; т. XV, стб. 139], Новгородская летопись по Списку Дубровского: «пришедщю за Дон, в поле чисто, в Мамаеву землю, на усть Непрядвы реки» [29, т. XLIII, с. 134]. Особенно важны летописные указания о размерах поля, на котором войска были развернуты на протяжении десяти верст: 
«И покрыша полки поле, яко на десяти версть отъ множества вои» [29, т. IV, ч. 1, с. 319; т. VI, вып. 1, с. 463; т. XLIII, с. 135].

Эти свидетельства полностью противоречат результатам палеогеографических и палеоботанических исследований, говорящих об отсутствии широких открытых пространств на официально признанном месте Куликовской битвы. Данное обстоятельство заставило в 2012 г. С.Н. Азбелева (1926-2017) отказаться от классической версии и попытаться найти действительное место битвы.

Главной географической «привязкой» места битвы к местности послужило указание источников, что сражение произошло «на усть рекы Непрядвы». Словом «устье» в современном русском языке обозначают впадение реки в другую реку, озеро, море. Но в Древней Руси, согласно словарю И.И. Срезневского, у него существовали и другие значения, одно из которых означало «исток реки: на усть - при истоке». К нему языковед дал пример из Новгородской первой летописи, где под 1323 г. читаем о завершении войны Новгорода со Швецией: «В лето 6831. Ходиша новгородци съ княземъ Юрьемъ и поставша город на усть Невы, на Ореховомъ острове; ту же приехавше послы великы от свеиского короля и докончаша миръ вечныи съ княземъ и с Новымьгородомь по старой пошлине» [30, стб. 1292; 29, т. III, с. 97, 339, 457]. Речь идет о строительстве крепости Орешек (ныне - Шлиссельбург) на Ореховом острове при истоке Невы, вытекающей из Ладожского озера.

Подобно Неве Непрядва в древности брала свое начало из озера. В одном из списков «Книги Большому чертежу» читаем: «а Упа река вытекла от Куликова поля с Муравского шляху из Волово озера от верху речки Непрядвы» [31, с. 59]. Это привело исследователя к мнению, что место битвы следует искать вблизи истока Непрядвы, приблизительно в 50 км от впадения ее в Дон [32].

Указанная локализация места битвы позволяет не только решить вопрос о возможности нахождения огромной массы людей, но и указывает на так долго ускользавшие от археологов могилы погибших в сражении. Согласно «Сказанию», великий князь Дмитрий для погибших «повеле ямы копати великие на превысоцем месте, и всех ям копаша 300 000» [1, с. 202]. Это свидетельство дает прямое указание на местонахождение могил. Обратившись к археологической карте Тульской области, находим соответствующие объекты. Первым наше внимание привлекает грунтовый могильник близ деревни Баташевка на мысу правого коренного берега Красивой Мечи при устье оврага, к северу от последнего. На пашне, на площади около 50 х 30 м, на высоте около 25 м над рекой были найдены фрагменты человеческих костей [33, с. 55. № 942 (81)]. Еще один грунтовый могильник предположительно обнаруживается на высоте более 35 м над Красивой Мечой около деревни Солодилово (Зайчовка) [33, с. 62-63. № 991 (50)]. Наконец, третий грунтовый могильник находится рядом с деревней Юдинка на правом склоне Орешинского оврага, спускающегося к долине Красивой Мечи. Его размеры составляют около 160 х 60 м, а сам могильник лежит на высоте 25-35 м над рекой. На пашне были обнаружены многочисленные остатки разрушенных человеческих скелетов со следами гробовищ [33, с. 66. № 1007 (57)].

И хотя эти захоронения известны достаточно давно, на них не обращали внимания, полагая, что они никоим образом не связаны с событиями 1380 г. Думается, что новые археологические разведки на этих местах подтвердят наш вывод.

Подводя итоги, можно констатировать, что при общем народонаселении русских княжеств примерно в 4 млн. чел., Дмитрию Донскому удалось мобилизовать 400 тыс. воинов, из которых 300 тыс. непосредственно сражались на Куликовом поле. Из них погибло 250 тыс. чел. При этом большинство из них являлись мужчинами самого репродуктивного возраста.

Отзвуки этого демографического эха дошли до нас в виде Дмитриевской родительской субботы - дня всеобщего поминовения усопших, совершаемого ежегодно в субботу перед днем памяти великомученника Димитрия Солунского, приходящимся на 26 октября (8 ноября по новому стилю). В православной литературе по поводу времени установления Дмитриевской родительской субботы мнения различны. Большинство полагает, что поминовение усопших в субботу перед днем памяти великомученика Димитрия Солунского было установлено князем Дмитрием Донским после Куликовской битвы. Другие считали, что Дмитриевская родительская суббота заменила собой языческие тризны, существовавшие ранее у славян и других народов.

Обращение к источникам показывает, что правы первые. Широко известен обычай поминовения умерших на сороковой день. В Москве известия о погибших были получены 11 сентября 1380 г., на четвертый день после битвы: «и сказаша им, которые побиты» [1, с. 202]. В этот же день на Куликовом поле похоронили последних из них. Волей случая сороковой день после получения сообщения о погибших пришелся на субботу 20 октября 1380 г. Традиция поминовения закрепилась. Сначала в этот день поминали именно тех, кто погиб на Куликовом поле, потом, начиная с XV в. он стал днем поминовения всех умерших. 


\section{Источники и литература}

1. Повести о Куликовской битве. М., 1959.

2. Афремов И.[Ф]. Куликово поле с реставрированным планом Куликовской битвы в 8-й день сентября 1380 года. Отрывок из Исторического обозрения Тульской губернии. М., 1849.

3. Масловский Д.Ф. Из истории военного искусства в России // Военный сборник. 1881. № 8. С. 212.

4. Голищын Н.С. Русская военная история. Ч. 1. СПб., 1877.

5. Луикий Е. Куликово поле // Исторический журнал. 1940. № 9. С. 44-54.

6. Карасев А.В., Оськин Г.И. Дмитрий Донской. М., 1950.

7. Строков А.А. История военного искусства. М. 1955.Т. 1: Рабовладельческое и феодальное общество.

8. Ашурков В.Н. На Куликовом поле. Тула, 1967.

9. Разин Е.А. История военного искусства. СПб., 1999. Т. 2: История военного искусства VI-XVI вв.

10. Пашуто В.Т. Образование Литовского государства. М., 1959.

11. Тизенгаузен В.Г. Сборник материалов, относящихся к истории Золотой Орды. М.; Л., 1941.Т. ІІ.

12. Кучкин В.А. Победа на Куликовом поле // Вопросы истории. 1980. № 8. С. 3-21.

13. Бескровный Л.Г. Куликовская битва // Куликовская битва. М., 1980. С. 6-20.

14. Урланис Б.Ц. Войны и народонаселение Европы. М., 1960.

15. Селезнев Ю.В. Мобилизационный потенциал Руси в конце XIV - начале XV в. (к постановке проблемы) // Н.И. Троицкий и современные исследования историкокультурного наследия Центральной России. Тула, 2002. Т. II: История, этнография, искусствоведение. С. 45-51.

16. Александровский А.Л. Палеопочвенные исследования на Куликовом поле // Куликово поле. Материалы и исследования. М., 1990. С. 60-70.

17. Кирпичников А.Н. Великое Донское побоище // Сказания и повести о Куликовской битве. Л., 1982. C. 291-305.

18. Шахмагонов Ф.Ф. Куликовская битва русского народа. Опыт реставрации исторического события // Бригантина. Сборник рассказов о путешествиях, поисках, открытиях. М., 1980. С. 4-34.

19. Петров E.A. Куликово поле в исторической памяти: формирование и эволюция представлений о месте Куликовской битвы 1380 г. // Древняя Русь. Вопросы медиевистики. 2002. № 3(13). С. 26-30.

20. Кирпичников А.Н. Военное дело на Руси в XIII-XV вв. Л., 1976.

21. Амелькин А.О., Селезнев Ю.В. Куликовская битва в свидетельствах современников и памяти потомков. М., 2010.

22. Пенской $B . B$. Возвращаясь к вопросу о численности русской рати на Куликовом поле // Археология евразийских степей. 2020. № 6. С. 337-350.

23. Пенской В.В. О численности войска Дмитрия Ивановича на Куликовом поле // Военное дело Золотой Орды. Проблемы и перспективы изучения. Материалы круглого стола, проведенного в рамках международного Золотоордынского форума (Казань, 30 марта 2011 г.). Казань, 2011. С. 157-161.

24. Булычев А.А. Живые и мертвые // Родина. 2010. № 8. С. 8-14.

25. Чеботарев A. В поисках Куликова поля [беседа с руководителями Верхне-Донской археологической экспедиции Государственного Исторического музея] // Нескучный сад. 2005. № 4 (15). С. 95-96.

26. Каталог реликвий Донского побоища, найденных на Куликовом поле. К 625-летию Куликовской битвы. М., 2005.

27. Копанев А.И. Население Русского государства в XVI в. // Исторические записки. М., 1959. Т. 64. C. $237-244$.

28. Сказания и повести о Куликовской битве. Л., 1982.

29. Полное собрание русских летописей. Т. ІІІ. М., 2000. Новгородская первая летопись старшего и младшего изводов. М., 2000; T. IV. Ч. 1. Новгородская четвертая летопись. М., 2000; T. VI. Вып. 1. Софийская первая летопись старшего извода. М., 2000; T. XV. Рогожский летописец. Тверской сборник. М., 2000; T. XVIII. Симеоновская летопись. М., 2007; T. XLIII. Новгородская летопись по списку П.П. Дубровского. М., 2004.

30. Срезневский И.И. Материалы для словаря древнерусского языка по письменным памятникам. СПб., 1903. T. 3.

31. Книга Большому чертежу. М.; Л., 1950.

32. Азбелев С.Н. География сражения на Куликовом поле // Древняя Русь. Вопросы медиевистики. 2013. № 3. C. 4-5; 2013. № 4. C. 12-20.

33. Археологическая карта России. Тульская область. Ч. 2. М., 2002. 


\section{Д.В. Вишнякова}

\section{Смертность населения Коми края в конце XIX - начале XX в.: возрастной состав умерших}

В статье анализируются отдельные показатели смертности населения Коми края в конце ХІХ-начале ХХ в. Выявляется возрастной состав умерших, с распределением по полу. На протяжении изучаемого времени смертность характеризовалась значительной концентрацией в младиих возрастньх группах. Смертность детей в возрасте до пяти лет составляла в среднем по краю 55-70\% от общего числа умериих.

Ключевые слова: Европейский Северо-Восток России, Коми край, смертность, возрастной состав умериих

\section{D.V. Vishnyakova}

\section{Mortality of the population of the Komi Region at the end of the - XIX beginning of the XX century: age composition}

The article describes some mortality rates of the population of the Komi Region in the late XIX-early XX century. The age composition of the deceased is revealed, with a distribution by gender. During the studied time, mortality was characterized by a significant concentration in younger age groups. The mortality rate of children under the age of five years averaged 55-70\% of the total number of deaths in the region.

Key words: European North-East, Komi region, mortality, age composition of the deceased

В данной работе внимание уделено вопросам изучения возрастного состава умерших по Коми краю в конце XIX - начале XX в. К рассматриваемой территории были отнесены Усть-Сысольский и Яренский уезды Вологодской губернии, а также Печорский уезд Архангельской губернии, объединяемые исследователями в понятие Коми край. В статье использованы материалы официальной статистики о естественном движении населения за 1897, 1905 и 1910 гг., опубликованные Центральным Статистическим комитетом Российской империи.

Оценка и анализ динамики возрастной смертности имеют особое значение. Рассматривая различные демографические показатели смертности, используют в том числе такие, как возрастной коэффициент смертности и возрастной состав умерших людей. Высчитать возрастной коэффициент смертности при изучении региональных демографических процессов XIX - начала XX в. довольно проблематично. Этот показатель вычисляется как отношение числа умерших в данном возрасте в течение календарного года к среднегодовой численности лиц данного возраста по текущей оценке. К сожалению, в имеющихся статистических источниках того времени не содержится в необходимом объеме информация о возрастном составе населения. В статье анализируется такой показатель, как возрастной состав умерших людей. Он отражает процент смертей в определенном возрасте (на 100 случаев), т.е. долю умерших в каждом возрастном интервале в общем числе умерших. Распределение умерших по возрасту зависит от возрастного состава населения, условий жизни, места жительства, эпидемий и т.д.

В конце XIX - начале XX в. уровень смертности населения в Российской империи был очень высоким. По подсчетам А.Г. Рашина, по Европейской России (50 губерний) в 1891-1895 гг. на тысячу человек населения приходилось 36,2 случаев смертей, в 1906-1910 гг. - 29,5. За те же периоды по Архангельской губернии уровень смертности составлял 26,6 и 26,5 смертей на тысячу человек, по Вологодской - 29,8 и 30,4 [1]. По Коми краю уровень смертности населения с 1897 по 1910 г. колебался от 23 до 31 \%о [2]. Привлеченные в исследовании материалы по Усть-Сысольскому, Яренскому и Печорскому уездам были объединены и представлены как данные по Коми краю в обобщенном виде, так как существенных расхождений в показателях этих

\footnotetext{
* Вишнякова Дарья Викторовна (Сыктывкар) - кандидат исторических наук, старший научный сотрудник сектора историко-демографических и историко-географических исследований Российского Севера Института языка, литературы и истории Коми НЦ УрО РАН, vishnyakova_dari@mail.ru
} 
трех уездов зафиксировано не было. Рассматриваемые группы населения были распределены соответственно полу и возрасту. Динамика возрастного состава умерших по Коми краю за 1897, 1905 и 1910 гг. отображена в таблицах 1,2 и 3.

Таблиия 1

Динамика возрастного состава умериих мужчин по Коми краю в конце XIX-начале XX в.

\begin{tabular}{|c|c|c|c|c|c|c|}
\hline \multirow{2}{*}{$\begin{array}{l}\text { Возрастные } \\
\text { группы, лет }\end{array}$} & \multicolumn{2}{|c|}{1897 г. } & \multicolumn{2}{|c|}{1905 г. } & \multicolumn{2}{|c|}{1910 г. } \\
\hline & Абс. & $\%$ & Абс. & $\%$ & Абс. & $\%$ \\
\hline $0-4$ & 1260 & 59,7 & 2121 & 65,3 & 2765 & 72,2 \\
\hline $5-9$ & 63 & 3 & 120 & 3,7 & 97 & 2,5 \\
\hline $10-14$ & 35 & 1,7 & 59 & 1,8 & 43 & 1,1 \\
\hline $15-19$ & 33 & 1,6 & 48 & 1,5 & 46 & 1,2 \\
\hline $20-24$ & 39 & 1,8 & 72 & 2,2 & 53 & 1,4 \\
\hline $25-29$ & 49 & 2,3 & 58 & 1,8 & 47 & 1,2 \\
\hline $30-34$ & 20 & 0,9 & 51 & 1,6 & 54 & 1,4 \\
\hline $35-39$ & 36 & 1,7 & 48 & 1,5 & 52 & 1,4 \\
\hline $40-44$ & 46 & 2,2 & 49 & 1,5 & 61 & 1,6 \\
\hline $45-49$ & 48 & 2,3 & 57 & 1,8 & 68 & 1,8 \\
\hline $50-54$ & 62 & 2,9 & 71 & 2,2 & 78 & 2 \\
\hline $55-59$ & 61 & 2,9 & 68 & 2,1 & 76 & 2 \\
\hline $60-64$ & 68 & 3,2 & 81 & 2,5 & 74 & 1,9 \\
\hline $65-69$ & 83 & 3,9 & 85 & 2,6 & 89 & 2,3 \\
\hline $70-74$ & 86 & 4,1 & 97 & 3 & 88 & 2,3 \\
\hline 75 и более & 123 & 5,8 & 165 & 5,1 & 140 & 3,7 \\
\hline Итого & 2112 & 100 & 3250 & 100 & 3831 & 100 \\
\hline
\end{tabular}

Источники: Статистика Российской империи: Движение населения в Европейской России за 1897, 1905, 1910 г. Т. 50, 84, 93. СПб., Петроград: ЦСК МВД, 1900, 1914, 1916.

Таблица 2

Динамика возрастного состава умерших женцин по Коми краю в конце XIX-начале XX в.

\begin{tabular}{|l|c|c|c|c|c|c|}
\hline \multirow{2}{*}{$\begin{array}{c}\text { Возрастные } \\
\text { группы, лет }\end{array}$} & \multicolumn{2}{|c|}{1897 г. } & \multicolumn{2}{c|}{1905 г. } & \multicolumn{2}{c|}{1910 г. } \\
\cline { 2 - 7 } & Абс. & $\%$ & Абс. & $\%$ & Абс. & \% \\
\hline $0-4$ & 1153 & 55,6 & 1851 & 62,8 & 2305 & 67,8 \\
\hline $5-9$ & 60 & 2,9 & 113 & 3,8 & 108 & 3,2 \\
\hline $10-14$ & 52 & 2,5 & 68 & 2,3 & 45 & 1,3 \\
\hline $15-19$ & 39 & 1,9 & 67 & 2,3 & 54 & 1,6 \\
\hline $20-24$ & 54 & 2,6 & 68 & 2,3 & 58 & 1,7 \\
\hline $25-29$ & 51 & 2,5 & 41 & 1,4 & 60 & 1,8 \\
\hline $30-34$ & 39 & 1,9 & 37 & 1,3 & 65 & 1,9 \\
\hline $35-39$ & 46 & 2,2 & 51 & 1,7 & 51 & 1,5 \\
\hline $40-44$ & 36 & 1,7 & 56 & 1,9 & 46 & 1,4 \\
\hline $45-49$ & 48 & 2,3 & 52 & 1,8 & 54 & 1,6 \\
\hline $50-54$ & 43 & 2,1 & 48 & 1,6 & 52 & 1,5 \\
\hline $55-59$ & 61 & 2,9 & 53 & 1,8 & 61 & 1,8 \\
\hline $60-64$ & 84 & 4,1 & 79 & 2,7 & 87 & 2,6 \\
\hline $65-69$ & 88 & 4,2 & 95 & 3,2 & 87 & 2,6 \\
\hline $70-74$ & 98 & 4,7 & 104 & 3,5 & 90 & 2,6 \\
\hline 75 и более & 121 & 5,8 & 165 & 5,6 & 176 & 5,2 \\
\hline Итого & 2073 & 100 & 2948 & 100 & 3399 & 100 \\
\hline
\end{tabular}

Источники: Статистика Российской империи: Движение населения в Европейской России за 1897, 1905, 1910 г. Т. 50 , 84, 93. СПб., Петроград: ЦСК МВД, 1900, 1914, 1916.

Из материалов табл. 1, 2 видно, что подавляющее число умерших по уездам в рассматриваемый период приходилось на детей в возрасте до пяти лет. Удельный вес умерших обоих полов в этом интервале составлял более половины от общего числа смертей. В следующих возрастных группах удельный вес умерших резко сокращался, и только лишь в старших возрастах доля смертности начинала несколько увеличиваться. По данным табл.1, доля смертей у мужского населения в возрастной категории до пяти лет в течение исследуемого 
периода увеличилась с 59,7 до 72,2 \%, т.е. на 12,5 \%. В дальнейшей возрастной категории, независимо от года наблюдения, происходило снижение доли смертности среди мужчин, колебания процента смертей были незначительными, на уровне 1-3 \%. Небольшие повышения доли умерших среди мужчин были отмечены в 1897 и 1905 гг. в возрасте от 60 лет, в 1910 г. - в группе от 65 лет.

Данные табл. 2 свидетельствуют о том, что среди женского населения основной процент смертей приходился так же на возраст от рождения до 5 лет. Тем не менее доля умерших в этом возрасте среди женского населения была несколько меньше в сравнении с мужской смертностью. С 1897 по 1910 г. удельный вес умерших в возрасте до 5 лет среди женского населения вырос на 12,2 \%, с 55,6 до 67,8. Распределение умерших по возрасту среди женщин происходило примерно так же, как и у мужчин. В 1897 г. в возрастном периоде от 55 лет, в 1905 и 1910 гг. в возрасте от 60 лет наблюдалось плавное увеличение показателя.

\section{Таблица 3 \\ Динамика возрастного состава умерших по Коми краю \\ в конце XIX - начале XX в., \%}

\begin{tabular}{|l|c|c|c|}
\hline $\begin{array}{l}\text { Возрастные } \\
\text { группы, лет }\end{array}$ & 1897 г. & 1905 г. & 1910 г. \\
\hline $0-4$ & 55,4 & 65,1 & 70,1 \\
\hline $5-9$ & 2,8 & 3,7 & 2,8 \\
\hline $10-14$ & 2,5 & 1,8 & 1,2 \\
\hline $15-19$ & 1,9 & 1,5 & 1,4 \\
\hline $20-24$ & 2,6 & 2,2 & 1,5 \\
\hline $25-29$ & 2,4 & 1,7 & 1,5 \\
\hline $30-34$ & 1,9 & 1,5 & 1,6 \\
\hline $35-39$ & 2,2 & 1,5 & 1,4 \\
\hline $40-44$ & 1,8 & 1,4 & 1,5 \\
\hline $45-49$ & 2,4 & 1,8 & 1,7 \\
\hline $50-54$ & 2,1 & 2,2 & 1,8 \\
\hline $55-59$ & 3,0 & 2,1 & 1,9 \\
\hline $60-64$ & 4,1 & 2,6 & 2,2 \\
\hline $65-69$ & 4,2 & 2,7 & 2,4 \\
\hline $70-74$ & 4,8 & 3,1 & 2,5 \\
\hline 75 и старше & 5,8 & 5,2 & 4,4 \\
\hline Итого & 100,0 & 100,0 & 100,0 \\
\hline
\end{tabular}

Источники: Статистика Российской империи: Движение населения в Европейской России за 1897, 1905, 1910 г. Т. 50, 84, 93 СПб., Петроград: ЦСК МВД, 1900, 1914, 1916.

стическое отношение родителей к смерти своих младенцев. Характерная для традиционного демографич го режима высокая детская смертность находила оправдание в общественных представлениях о мироустройстве, что выражалось в определенных поведенческих нормах, отношении к жизни детей [5]. Исследователями также обращается внимание на зависимость младенческой смертности, в первую очередь, от традиционных практик ухода за детьми, распространенных среди определенных конфессиональных и этнических групп. Для детей до года губительной оказывалась практика раннего прикорма и раннего прекращения грудного вскармливания, приводившая к развитию желудочно-кишечных инфекций и повышавшая риск смерти от диареи. Эта практика была в большей степени распространена среди великорусского населения империи. Исследования в европейской демографической истории также показывают зависимость уровня младенческой смертности от практик вскармливания. Более высокая смертность в южных регионах Германии объясняется коротким периодом грудного вскармливания или практически полным его отсутствием по сравнению с северными регионами. Аналогично, низкая детская смертность в Швеции по сравнению с соседней Финляндией объяснялась большей распространенностью раннего прикорма среди финнов [6].

В Коми крае в конце XIX - начале XX в., несмотря на улучшение состояния системы здравоохранения, развитие земской медицины, рост числа больниц и сельских лечебниц, на детскую смертность большое влияние продолжал оказывать влияние недостаточный уход за детьми. Этнографические описания свидетельствуют об условиях содержания новорожденных: «За маленькими детьми присмотр считается как будто излишним, 
отчего они подвергаются различным болезням. Грудные младенцы, особенно во время полевых работ, часто с утра до вечера лежат в берестяных люльках и питаются одной соской-тряпкой, в которую положено немного нажеванного хлеба» [7]. У коми крестьян также существовала практика раннего прикорма, когда ребенка с первых дней начинали прикармливать коровьим молоком, позже жеваным хлебом, кашей, супом.

Динамика смертности возрастных групп населения Коми края с 1897 по 1910 г. показала увеличение удельного веса детских смертей в общем числе умерших. Рассмотренная возрастная структура смертности свидетельствует о высокой концентрации в детских возрастах и относительно низкой в старших возрастных группах. Очень высокая детская смертность обоих полов выступает как фундаментальная структурная особенность возрастного распределения смертности в изучаемый период, она оказывала огромное влияние как на общую смертность, так и на ожидаемую продолжительность жизни.

\section{Источники и литература}

1. Рашин А.Г. Население России за сто лет (1811-1913 гг.). М., 1956. С. 187-188.

2. Вишнякова Д.В. Динамика рождаемости и смертности населения Коми края во второй половине XIX - начала XX в. // Социальные трансформации северного региона: исторический опыт и современность. Сборник статей. Сыктывкар, 2021. С. 81.

3. Рашин А.Г. Население России за сто лет (1811-1913 гг.). М., 1956. С. 195.

4. Миронов Б.Н. Социальная история России периода империи (XVIII - начало XX в.): Генезис личности, демократической семьи, гражданского общества и правового государства. СПб., 2003. Т. 1. С. 199.

5. Голикова C.B. Отношение к детской смертности в традиционной культуре русских Урала конца XVIII - начала XX в. // Уральский исторический вестник. 2017. № 1. С. 64.

6. Натхов Т.В., Василенок Н.А. Младенческая смертность в пореформенной России: динамика, региональные различия и роль традиционных норм // Историческая информатика. 2020. № 3. С. 71-88.

7. Материалы для географии и статистики России. Архангельская губерния. СПб., 1865. С. 12. 


\title{
М.Ю. Макаренко*
}

\section{Состав и структура населения Северного Кавказа по материалам переписи 1926 года}

\begin{abstract}
В статье анализируются численность, половозрастной и этнический состав населения на Северном Кавказе в первой четверти XXI в. Рассматриваются особенности учета половозрастного состава и приниипь учета населения. Показана доля грамотного населения.
\end{abstract}

Ключевые слова: перепись, городское население, сельское население, этнический состав и половозрастная структура населения, грамотность населения

\section{M.Yu. Makarenko}

\section{Composition and structure of the population of the North Caucasus based on the 1926 census}

The article analyzes the size, age, sex and ethnic composition of the population in the North Caucasus in the first quarter of the 21st century. The features of accounting for the age and sex composition and the principles of accounting for the population are considered. The proportion of literacy settlers in the permanent population of the region is shown.

Key words: population census, urban population, rural population, ethnic composition and age and sex structure of the population, literacy of the population

Цель предлагаемых материалов - проанализировать социально-демографическую картину Северного Кавказа, зафиксированную материалами переписи 1926 г. Правовая основа переписи 1926 г. - постановление ЦИК и СНК СССР от 3 сентября 1926 г. Подготовка к переписи проводилась в спокойной и деловой обстановке. Этот факт выгодно отличает ее от подготовок к предыдущей и последующим советским переписям.

Первоначально руководство работой над подготовкой переписи поручается заведующему отделом демографии ЦСУ СССР В.Г. Михайловскому, который до этого неоднократно говорил о необходимости ее проведения: «Перепись 1920 г. в настоящее время чрезвычайно устарела, хотя со дня её производства прошло всего 6 лет. Голодовки 1920-1921 года... эпидемии сыпного и возвратного тифов унесли в могилу несколько миллионов человек, но точно подсчитать число жертв этого грозного периода наша статистика не в состоянии... после 1922 г. рождаемость населения Союза быстро поднялась... смертность... опустилась ниже нормы мирного времени... Красная армия была демобилизована... Беженское движение улеглось... Возобновилось переселенческое движение, притом в других направлениях сравнительно с довоенным временем... Но скольконибудь полных и точных данных для учета всех этих явлений в распоряжении нашей статистики не имеется... Строго говоря, мы почти ничего не знаем о современном населении Союза» [1]. В.Г. Михайловскому, не дожившему немногим более двух месяцев до проведения переписи, принадлежит разработка её личного листка, семейной карты и владенной ведомости. После его смерти коллегия ЦСУ поручает руководство по проведению, разработке и публикации материалов переписи О.А. Квиткину.

Итоги проведения переписи 1926 г., проблемы, связанные с предстоящей разработкой полученных материалов, обсуждались на Всесоюзной статистической конференции в январе - феврале 1927 г., где были заслушаны отчеты с мест о ходе переписи. Отчеты местных статистических бюро о проведении переписи вошли в состав фонда ЦСУ СССР РГАЭ [2]. Среди них - отчет заведующего отделом переписи КСУ А.И. Гозулова [3], содержащий подробную информацию об особенностях подготовки и проведения переписи в СевероКавказском крае.

Подчеркивая, что в целом перепись прошла удовлетворительно, А.И. Гозулов отмечает недостатки организации: текучесть переписного состава (особенно в городах), возникшую в результате низкой оплаты и осложнения погодных условий (зимней распутицы), нехватку переводчиков в национальных областях и т. д. Текучесть

\footnotetext{
* Макаренко Мария Юрьевна (Краснодар) - доктор исторических наук, профессор кафедры педагогики и межкультурных коммуникаций Академии маркетинга и социально-информационных технологий-ИМСИТ.
} 
кадров в городах объяснялась, по всей видимости, тем, что в них уровень жизни был выше и запросы статистиков превосходили финансовые потребности персонала, задействованного в сельской местности.

Статистик обращает внимание на то, что, несмотря на долгую разъяснительную и агитационную работу государственных и общественных краевых организаций (например, издание в Ростове в преддверии переписи тиражом 20000 экземпляров брошюры «Всесоюзная перепись населения 17-го декабря 1926 года» [4]), «в сознании населения (особенно на окраинах) твердо укоренилась уверенность в том, что переписывают для налоговых целей», сведения о занятиях и имуществе скрываются, в результате - регистраторам «приходилось заходить по два и больше раз за получением этих данных» [5].

Особенно трудно доставалась информация в национальных областях. Так, во Владикавказе «в отсутствии мужчин женщины национальных меньшинств не давали никаких показаний и просто отмалчивались или оказывались непонимающими не только русский язык, но и свой родной. Вместо ответов на переписные вопросы, регистраторам приходилось выслушивать жалобы на болезнь, бедность, перед ними демонстрировались квитанции об уплате налогов, образцы пищи». В целом А.И. Гозулов подчеркивает: «Перепись, по единодушному заключению округов, в сельской местности проводилась значительно лучше, чем по городам» [6]. Хотя обычно в статистической практике ситуация складывается по-другому.

На 17 декабря 1926 г. (критический момент переписи) Северо-Кавказский край занимал 1/73 часть СССР (292 894 кв. км) [7]. Перепись зафиксировала тот этап в жизни региона, когда восстановление нарушенного войнами, эпидемиями и голодом народного хозяйства приблизилось к завершению. В 1925 г. размеры посевов составили $3 / 4$ довоенной площади.

В годы нэпа сохранялась неоднородность уровней грамотности населения (показатель рассчитан среди возрастных когорт от 9 лет) внутри пространства Северного Кавказа. В 1926 г. в Чечне и Ингушетии грамотны менее четверти жителей (показатель все еще ниже среднерегионального уровня Северного Кавказа, зафиксированного в 1897 г.), объединенный показатель по четырем округам Северо-Кавказского края, послуживших основой образованного в 1937 г. Краснодарского края - около 60 \%, на Дону - немногим более 60\%. В будущем тенденции развития процесса продолжились: к 1939 г. грамотное население составляло в Краснодарском крае 83,7 \%, в Ростовской области - 85,1\% [8].

Согласно материалам переписи 1926 г. совокупное население 12 округов (Армавирского, Донецкого, Донского, Кубанского, Майкопского, Сальского, Ставропольского, Сунженского, Таганрогского, Терского, Черноморского, Шахтинско-Донецкого), шести национальных областей (Адыгее-Черкесской, Ингушской, Кабардино-Балкарской, Карачаевской, Северо-Осетинской, Чеченской), Черкесского автономного округа, двух самостоятельных городов (Грозного и Владикавказа) Северо-Кавказского края составляло 8364086 чел. [9].

За тридцатилетний период (январь 1897 - декабрь 1926 г.) в среднем в год население Северного Кавказа увеличивалось на 2,04 \%, всего между переписями - на 59,3 \%. Темпы роста городского и сельского населения составили 127,9 и $48,3 \%$ [10].

В декабре 1926 г. в стране насчитывалось 1929 городских населенных пунктов; из них в Российской Федерации - 1 240; на территории Северо-Кавказского края - 66. Еще семь находились в Дагестанской АССР [11], присоединенной к краю в 1931 г. По постановлению ВЦИК и СНК собственно городской статус имели Азов, Анапа, Армавир, Баталпашинск, Владикавказ, Геленджик, Георгиевск, Грозный, Ейск, Ессентуки, Железноводск, Кисловодск, Краснодар, Красный Сулин, Кропоткин, Майкоп, Миллерово, Минеральные Воды, Моздок, Нальчик, Нахичевань, Новороссийск, Новочеркасск, Прикумск, Пятигорск, Ростов-на-Дону, Сальск, Сочи, Ставрополь, Таганрог, Темрюк, Тихорецк, Туапсе, Шахты. Соотношение городского и сельского населения по административным единицам Северо-Кавказского края представлено в табл. 1, содержание которой визуализировано на графике.

Городское и сельское население Северо-Кавказского края (на 17 декабря 1926 г.)

Таблица 1

\begin{tabular}{|l|c|c|c|c|c|}
\hline \multirow{2}{*}{\multicolumn{1}{c|}{ Единица АТД }} & Общая & \multicolumn{2}{c|}{ Городское население } & \multicolumn{2}{c|}{ Сельское население } \\
\cline { 3 - 6 } & численность & Абс. & Отн., $\%$ & Абс. & Отн., \% \\
\hline Армавирский & 927367 & 153679 & 16,57 & 773688 & 83,43 \\
\hline Донецкий & 374720 & 15076 & 4,02 & 359644 & 95,98 \\
\hline Донской & 1132666 & 451007 & 39,82 & 681659 & 60,18 \\
\hline Кубанский & 1489185 & 210956 & 14,17 & 1278229 & 85,83 \\
\hline Майкопский & 330044 & 55879 & 16,93 & 274165 & 83,07 \\
\hline Сальский & 471898 & 6902 & 1,46 & 464996 & 98,54 \\
\hline Ставропольский & 727625 & 60454 & 8,31 & 667171 & 91,69 \\
\hline Сунженский & 34887 & - & - & 34887 & 100,00 \\
\hline
\end{tabular}


Окончание табл. 1

\begin{tabular}{|l|c|c|c|c|c|}
\hline \multirow{2}{*}{ Единица АТД } & Общая & \multicolumn{2}{c|}{ Городское население } & \multicolumn{2}{c|}{ Сельское население } \\
\cline { 3 - 6 } & численность & Абс. & Отн., $\%$ & Абс. & Отн., \% \\
\hline Таганрогский & 268410 & 86465 & 32,21 & 181945 & 67,79 \\
\hline Терскийокруг & 643412 & 184777 & 28,72 & 458635 & 71,28 \\
\hline Черноморский & 291438 & 112484 & 38,60 & 178954 & 61,40 \\
\hline Шахтинско-Донецкий & 540411 & 123617 & 22,87 & 416794 & 77,13 \\
\hline Адыгее-Черкесская & 113494 & - & - & 113494 & 100,00 \\
\hline Ингушская & 75141 & 1274 & 1,70 & 73867 & 98,30 \\
\hline Кабардино-Балкарская & 204007 & 12909 & 6,33 & 191098 & 93,67 \\
\hline Карачаевская & 64623 & - & - & 64623 & 100,00 \\
\hline Северо-Осетинская & 152425 & 1618 & 1,06 & 150807 & 98,94 \\
\hline Черкесский авт. округ & 37005 & - & - & 37005 & 100,00 \\
\hline Чеченская & 309886 & 2976 & 0,96 & 306910 & 99,04 \\
\hline г. Владикавказ & 78347 & 78347 & 100,00 & - & - \\
\hline г. Грозный & 97095 & 97095 & 100,00 & \multicolumn{2}{c|}{-} \\
\hline Итого по краю & 8364086 & 1655515 & 19,79 & 6708571 & 80,21 \\
\hline
\end{tabular}

Подсчитано по: Всесоюзная перепись населения 1926 года... Т. 5. С. 50.

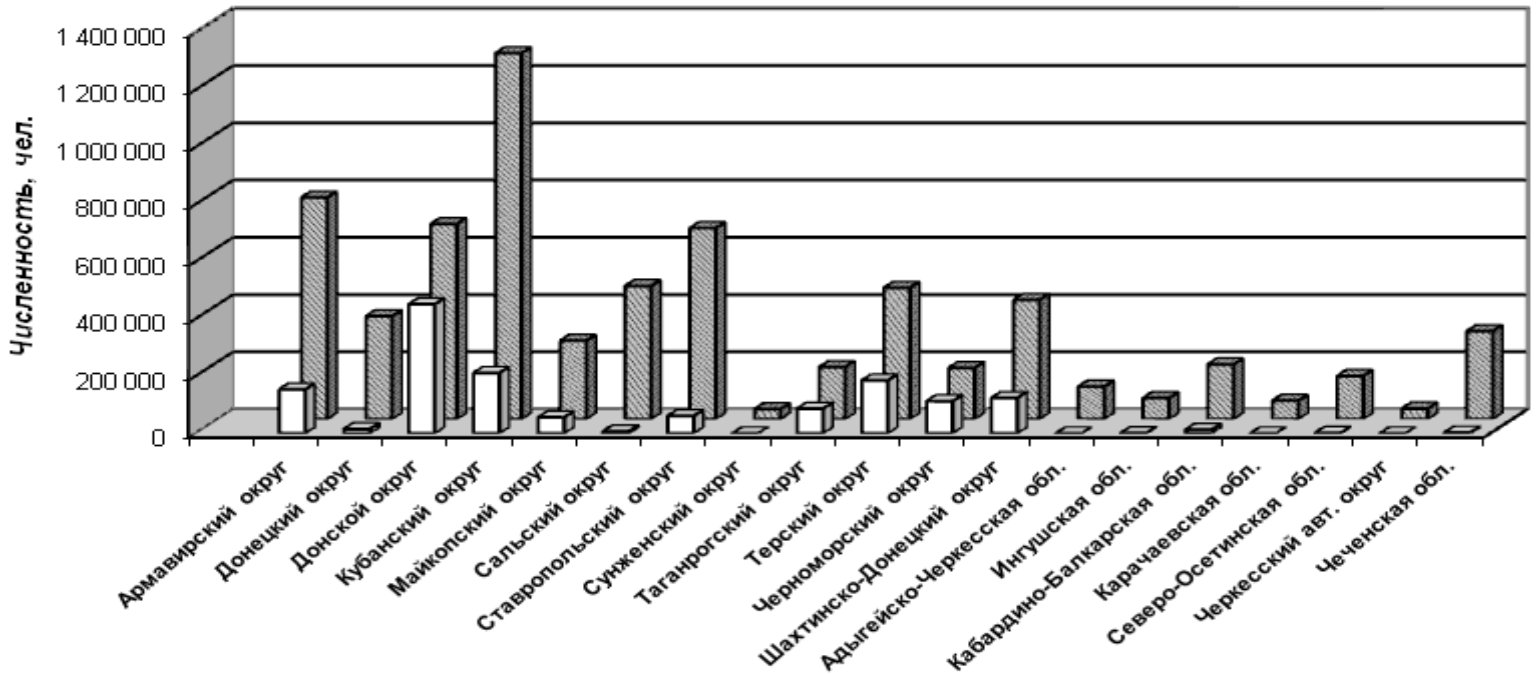

口Городское население øсельское население

Распределение городского и сельского населения (на 17 декабря 1928 г.).

При оценке материалов переписи необходимо учитывать, что они дают представление о наличном, а не о постоянном населении, т. е. крестьянин, находившийся 17 декабря 1926 г. в городе, записывался как городской житель [12]. Разница между наличным и постоянным населением в общесоюзных масштабах составляла всего 2 \%. На аграрном Юге страны, характеризующемся меньшей подвижностью населения, она была еще меньшей - 1,4 \% [13]. Таким образом, статистики удачно выбрали момент проведения переписи - середину декабря, поскольку «зима является самым подходящим временем для производства переписей... население находится в состоянии наибольшего покоя» [14].

Самым крупным из административно-территориальных образований Северо-Кавказского края был Кубанский округ: в нем проживало 17,8\% населения. За ним следовали Донской (13,5 \%), Армавирский (11,1%), Ставропольский $(8,7$ \%) и Терский $(7,7$ \%). К группе «средних» относились Шахтинско-Донецкий, Сальский, Донецкий, Майкопский, Таганрогский и Черноморский округа. Относительный вес их населения в общей массе жителей Северо-Кавказского края составлял соответственно от 6,5 до 3,5 \%. Из национальных областей наи- 
большим был демографический вклад Чеченской - 3,8 \%. Остальные административно-территориальные единицы имели менее 250 тыс. жителей [15].

Прежде чем начинать характеристику национального состава населения Северного Кавказа, рассмотрим содержание, которое вкладывали разные переписи в понятие этнической принадлежности: перепись 1897 г. отождествляла народность с родным языком, в 1920 г. руководствовались «социально-психологическими мотивами определения», перепись 1926 г. исходила из «генетического определения». Таким образом, понятийный аппарат в этом вопросе не совпадал. Один из ярких примеров результата несовпадения - факт, приведенный А.И. Гозуловым: в Донецком округе относительный вес украинцев вырос с 2,5 \% в 1920 г. до 63,0 \% в 1926 г. [16].

Кроме регистрации народности, перепись 1926 г. регистрировала родной язык, понимая под ним тот, которым опрашиваемый лучше всего владеет или на котором обыкновенно говорит, перепись 1920 г. считала родной язык тот, на котором говорит семья опрашиваемого; перепись 1897 г. определяла родным тот, который считает таковым сам опрашиваемый. Как показывает анализ материалов 1926 г., понятия народности и родного языка в некоторых случаях оказывались несовпадающими. Так, уже в одном из выпусков «Кратких сводок» материалов переписи обращается внимание «на явление, обнаруженное переписью, в особенности по Северо-Кавказскому краю, именно резкое превышение доли населения, показавшего своим родным языком русский язык, сравнительно с учетом по народности, повышения за счет, главным образом, украинцев и частью белорусов».

Согласно материалам переписи 1926 г., 45,9 \% многонационального населения Северного Кавказа составляли русские; 37,1 \% - украинцы; чечены (чеченцы) - 3,5; армяне и осетины - по 1,9; кабардинцы - 1,7; немцы - 1,1; ингуши - 0,9; черкесы - 0,8; карачаи (карачаевцы) - 0,7 \%; на территории региона проживали относительно небольшие группы евреев, балкарцев, греков, татар, грузин, абазин, калмыков, ногайцев, белорусов, поляков [17]. Таким образом, перепись зафиксировала выраженное преобладание славян в общей массе населения: совокупный вес только двух самых крупных славянских этносов (русских и украинцев) - 83,0 \%.

Представители титульных этносов составляли 94,0 \% населения Чеченской АO, 93,1 - Ингушской АО, 84,2 - Северо-Осетинской АО, 81,3 - Карачаевской АО, 73,3 - (60,0 \% кабардинцы и 16,3 \% балкары (балкарцы)) Кабардино-Балкарской АО. Значение славянской составляющей основательно повышалось в самой северо-западной области - Адыгее-Черкесской (русских - 25,6 \%, украинцев - 23,3%). Этнически пестрым было население Черкесского автономного округа: кабардинцы - 33,3 \%; бескесек-абаза - 29,7; ногайцы - 16,8; черкесы - 7,2; русские - всего 4; украинцы - 3,7; греки, татары, евреи - менее 1\%. В национальных областях установилась тенденция понижения относительного веса русских в составе населения городов: так, во Владикавказе в 1913 г. они составляли 67,1%, в 1926 г. - 57,7 \%; доля титульного этноса, напротив, растет [18].

В большинстве округов по удельному весу преобладали русские, а в Донецком, Кубанском, Таганрогском и Черноморском - украинцы. Наиболее дисперсным был этнический состав населения юго-востока региона - многонационального Дагестана: аварцы составляли 17,0\%; даргинцы - 13,8; русские - 12,5; лезгины - 11,5; кумыки - 11,2; лаки - 5,1; табасараны - 4,1; ногайцы - 3,3; тюрки - 3; чеченцы - 2,8\%; в республике также проживали кайтаки, евреи, рутулы, армяне, украинцы, персы, татары, туркмены, немцы, представители других народностей [19].

Группировка населения по полу и возрасту - одна из важнейших социально-демографических характеристик. Хотя переписью 1926 г. возрастное строение населения и было зафиксировано с одногодичным интервалом, В.П. Данилов обращает внимание на то, что использование этой группировки затрудняется в результате аккумуляции возрастов - округлении количества прожитых лет, характерным для неграмотного и малограмотного населения. Аккумуляция имеет место вокруг показателей, оканчивающихся на «0» $(10,20,30$ лет и т. д.), в меньшей степени - на «5» $(5,15,25$ лет и т. д.), в еще меньшей - на «8» и «12» [20]. Основная причина аккумуляции в 1920-е гг. - простое незнание населением своего точного возраста. Уполномоченный ЦСУ по переписным работам в Дагестане описывал сложившуюся там ситуацию следующим образом: «точно возраста никто не знает и ответы в пятках и десятках... весьма часты... Неизменно вопрос о возрасте вызывает улыбку или смех, до того он не обычен» [21].

В демографической статистике разработаны специальные приемы демпфирования данных переписей о возрастном строении населения [22]. Однако полученные в результате демпфирования показатели неизбежно условны, поскольку выравниваются не только неравномерности, вызванные аккумуляцией, но и реальные колебания. Поэтому, как отмечал В.П. Данилов, для исторического исследования наиболее приемлемо употребление реальных данных переписи, объединенных в пятилетние возрастные группы: такая группировка значительно сглаживает последствия возрастной аккумуляции. Кроме аккумуляции существовала еще одна причина искажения реальных данных возрастного строения, преимущественно женской его «половины». В уже упоминавшейся брошюре «Всесоюзная перепись 17-го декабря 1926 года» специально пояснялось: «на 
вопрос о годах, часто... женщины уменьшают свой возраст. Напрасно. Кроме регистратора никто не увидит карточки, а ему не до возраста какой-нибудь Марьи Ивановны» [23].

Таблицุа 2

Гендерная картина по административным единицам края

\begin{tabular}{|c|c|c|c|c|}
\hline \multirow{3}{*}{$\begin{array}{c}\text { Округа, области, } \\
\text { города }\end{array}$} & \multicolumn{4}{|c|}{ Пол } \\
\hline & \multicolumn{2}{|c|}{ Мужчины } & \multicolumn{2}{|c|}{ Женщины } \\
\hline & Абс. & Отн., \% & Абс. & Отн., \% \\
\hline Армавирский & 440640 & 47,51 & 486752 & 52,49 \\
\hline Адыгее-Черкесская & 55893 & 49,25 & 57588 & 50,75 \\
\hline г. Владикавказ & 39667 & 50,63 & 38679 & 49,37 \\
\hline г. Грозный & 50358 & 51,87 & 46729 & 48,13 \\
\hline Донской & 542678 & 47,93 & 589592 & 52,07 \\
\hline Донецкий & 175182 & 46,75 & 199527 & 53,25 \\
\hline Ингушская & 37462 & 49,86 & 37671 & 50,14 \\
\hline Карачаевская & 32437 & 50,20 & 32176 & 49,80 \\
\hline Кабардино-Балкарская & 103097 & 50,54 & 100909 & 49,46 \\
\hline Кубанский & 711552 & 47,78 & 777536 & 52,22 \\
\hline Майкопский & 157965 & 47,85 & 172170 & 52,15 \\
\hline Сальский & 224792 & 47,64 & 247098 & 52,36 \\
\hline Северо-Осетинская & 75840 & 49,75 & 76595 & 50,25 \\
\hline Ставропольский & 346232 & 47,58 & 381393 & 52,42 \\
\hline Сунженский & 16830 & 48,24 & 18058 & 51,76 \\
\hline Таганрогский & 128968 & 48,05 & 139426 & 51,95 \\
\hline Терский & 308439 & 47,94 & 334930 & 52,06 \\
\hline Черноморский & 146878 & 50,40 & 144559 & 49,60 \\
\hline Чеченская & 159223 & 51,39 & 150637 & 48,61 \\
\hline Черкесский & 18831 & 50,90 & 18165 & 49,10 \\
\hline Шахтинско-Донецкий & 253642 & 46,59 & 290754 & 53,41 \\
\hline
\end{tabular}

Источники: Гозулов А.И. Морфология населения. Опыт изучения строения основных свойств населения СевероКавказского Края по данным трех народных переписей - 1926, 1920 и 1897 г.г. Ростов н/Д., 1929. С. 133.

Юноши в возрасте 20-24 лет составляли 10,7 \% всех мужчин региона, а следующая за ними группа только 7,7 \% (гендерная картина представлена в табл. 2). Среди женских возрастов такого резкого перепада не наблюдалось: 20-24-летние - 10,4 \% женской «половины» населения, 25-29-летние - 9,0 \%. Смягчался перепад между отмеченными когортами и в составе населения РСФСР: 20-24-летние - 9,4 \% всех мужчин, 25-29-летние - 7,51 \%; соответствующие женские возраста - 9,30 и 8,41 \% [24].

Численность мужчин превосходила численность женщин только в двух возрастных группах - 0-4 и 10-14 лет, причем в последней совсем незначительно. Во всех остальных группах преобладали женщины, относительный вес которых составлял 52 \% населения (по РСФСР - 52,2 \%) [25], т. е. на 1000 мужчин приходилось 1085 женщин (аналогичный показатель по Союзу ССР - 1 070) [26]. Как и в целом по стране, на Кубани дисбаланс в численности мужчин и женщин усиливался в самых призывных возрастных группах - 25-29, 30-34, 35-39 лет, в которых на 1000 мужчин приходилось соответственно 1 270, 1147 и 1222 женщины [27].

В заключение следует сказать, что материалы переписи 1926 г. остаются наиболее репрезентативным источником, зафиксировавшим начальный этап демографической модернизации славянского населения региона. Половозрастная структура, зафиксированная переписью, еще достаточно четко отражала последствия войн, голода, эпидемий. На левой («мужской») половозрастной стороне пирамиды заметен перепад между когортами 20-24 и 25-29-летних - грань, разделившая поколения, пассивно и активно пережившие годы войн. Половозрастное строение городского и сельского населения имело ряд особенностей. Поскольку векторы демографической модернизации быстрее проникали в стереотипы поведения горожан, рождаемость в городах была ниже, количество детей и подростков меньшим. Среди городского населения понижался относительный вес женщин. Анализ гендерной картины Северо-Кавказского края по единицам АТД показывает преобладание женщин в структуре населения практически всех округов (за исключением Черноморского и Черкесского), мужчин - в национальных областях (за исключением Адыгее-Черкесской и Ингушской). 


\section{Источники и литература}

1. Михайловский В.Г. Всесоюзная перепись населения 1926 года. М., 1926. С. 3-4.

2. Российский Государственный архив экономики (далее - РГАЭ.). Ф. 1562. Оп. 336. Д. 44-49.

3. Там же. Д. 44. Л. 31-33.

4. Всесоюзная перепись населения 17-го декабря 1926 года. Ростов н/Д, 1926.

5. РГАЭ. Ф. 1562. ОП. 336. Д. 44. Л. 31.

6. РГАЭ. Ф. 1562. Оп. 336. Д. 44. Л. 32.

7. Гозулов А.И. Экономическая география Северного Кавказа. Ростов н/Д, 1927. С. 5.

8. Всесоюзная перепись населения 1939 года: Основные итоги / Под ред. Ю.А. Полякова. М., 1992. С. 40.

9. Всесоюзная перепись населения 1926 года: в 56 т. М., 1928-1935. Т. 5. С. 50.

10. Гозулов А.И. Морфология населения. Опыт изучения строения основных свойств населения СевероКавказского Края по данным трех народных переписей - 1926, 1920 и 1897 г.г. Ростов н/Д., 1929. С. $120-124$.

11. Остапенко И.П. Индустриализация и урбанизация // Население России в XX веке. Исторические очерки: в 3 т. М., 2000. Т. 1: 1900-1939. С. 219. C. 29.

12. Данилов В.П. Советская доколхозная деревня: население, землепользование, хозяйство. М., 1977.

13. Подсчитано по: Всесоюзная перепись населения 1926 года...Т. 39. С. 50-51.

14. Роецкий К. Наличное население Юго-востока России // Статистика Юго-восточного Края. 1921. № 1-2. C. 2.

15. Гозулов А.И. Экономическая география Северного Кавказа. Ростов н/Д, 1927. С. 26.

16. Гозулов А.И. Морфология населения... С. 10, 11, 13.

17. Жиромская В.Б. Население России в 1920-е годы: демографическая характеристика, демографические процессы // Население России в ХХ веке... Т. 1. С. 146.

18. Центральный государственный архив РСО - Алания (ЦГА РСО - А. Ф. Р-56.) Оп. 5. Д. 278. Л. 5.

19. Жиромская В.Б. Население России в 1920-е годы... С. 146-147.

20. Данилов В.П. Советская доколхозная деревня... С. 22.

21. РГАЭ. Ф. 1562. ОП. 336. Д. 44. Л. 68.

22. См., напр.: Гозулов А.И. Морфология населения... С. 140-154; Гозулов А.И., Григорьяни М.Г. Народонаселение СССР (Статистическое изучение численности, состава и размещения). М., 1969. С. 61-62.

23. Всесоюзная перепись населения 17-го декабря 1926 года... С. 10.

24. Всесоюзная перепись населения 1926 года: в 56 т. М., 1928-1935. М., 1929. Т. 17. С. 66.

25. Жиромская В.Б. После революционных бурь: Население России в первой половине 20-х годов. M., 1996. C. 13.

26. Всесоюзная перепись населения 1939 года: Основные итоги / Под ред. Ю.А. Полякова. М., 1992. С. 20. 27. Подсчитано по: Всесоюзная перепись населения 1926 года... Т. 5. С. 138, 162, 170, 208. 


\title{
H.M. Игнатова*
}

\section{Воспроизводство населения у спецпереселенцев Европейского Севера в 1930-е гг.: кризис и адаптация}

\begin{abstract}
В статье на материалах трех регионов Европейского Севера, входивших в 1929-1936 г2. в Северньй край (Архангельская, Вологодская и Коми автономная области) рассматривается воспроизводство населения в спецпоселках через анализ рождаемости и смертности спецппереселенцев-«бывших кулаков» (трудпереселенщев) в 1930-е г2. Рассмотрен уровень смертности и рождаемости, а также соотношение этих показателей. Выявлены многократное превышение смертности над рождаемостью и усиленная естественная убыль у спецпереселенцев в первой половине 1930-х г2. Стабилизация ситуации в середине 1930-х г2. и превышение рождаемости над смертностью во второй половине 1930-х г2. позволяет говорить о преодолении кризиса воспроизводства, адаптации и улучшения показателей естественного движения у спейпреселенцев.
\end{abstract}

Ключевые слова: спецпереселенщь-«бывшие кулаки», воспроизводство населения, смертность, рождаемость

\section{N.M. Ignatova}

\section{Population reproduction among forced migrants of the European North in the 1930s: crisis and adaptation}

The article is based on the materials of three regions of the European North, which were part of the Northern Territory in 1929-1936 (Arkhangelsk, Vologda and Komi Autonomous Regions) the article considers the reproduction of the population in special settlements through the analysis of the birth rate and mortality of forced migrants - "former kulaks» (labor settlers) in the 1930s. The level of mortality and birth rate, as well as the ratio of these indicators, is considered. A multiple excess of mortality over birth rate and increased natural decline in violent migrants in the first half of the 1930s were revealed. The stabilization of the situation in the mid-1930s and the excess of fertility over mortality in the second half of the 1930s suggests that the crisis of reproduction, adaptation and improvement of natural movement indicators in violent migrants has been overcome.

Key words: forced migrants - «former kulaks», population reproduction, mortality, birth rate

Проблема изучения рождаемости и смертности в спецпоселках напрямую связана с наличием и анализом статистических данных. В 1990-е гг. исследователи принудительных миграций, в том числе «кулацкой ссылки», неоднократно высказывали недоверие к опубликованной статистике НКВД-МВД. Например, исследователь В.М. Кириллов писал: «На рубеже 20-30-х годов в связи с процессами раскулачивания, голода, идеологического и политического диктата система сбора статистических сведений в стране была нарушена и верить до конца отчетам ГУЛАГа не приходится» [1]. В работе, посвященной высланным на спецпоселения раскулаченным, Т.И. Славко справедливо отмечала, что обобщенные данные должны подвергаться тщательному анализу, так как источники регионального характера показывают «крайне неудовлетворительный учет и отчетность с мест поселения спецпереселенцев» [2].

Исследователь В.Н. Земсков, опубликовавший обширные комплексы рассекреченных документов, неоднократно выступал в защиту данных НКВД-МВД: «Нельзя подделать находящийся в государственном хранении целый архивный фонд с тысячами единиц хранения, куда входит и огромный массив первичных материалов. Все эти документы были подвергнуты тщательному источниковедческому анализу, и их подлинность установлена» [3]. В 1995 г. на страницах журнала «Социологические исследования» состоялась дискуссия между В.Н. Земсковым и исследователем С. Максудовым. Было опубликовано письмо С. Максудова, где он пишет, что данные В.Н. Земскова вызывают вопросы, в частности, нет показателей по смертности среди «ку-

\footnotetext{
* Игнатова Надежда Максимовна (Сыктывкар) - кандидат исторических наук, заведующий сектором историко-демографических и историко-географических исследований Российского Севера Института языка, литературы и истории Коми НЦ УpO РАН, ignatova11@rambler.ru.
} 
лацкой ссылки» в первые годы высылки, в 1930-1931 гг. [4]. В.Н. Земсков писал в ответной статье: «По меркам того времени, качество учета было достаточно высоким, так как высланные кулаки фактически являлись поднадзорными, и их учет велся гораздо строже и скрупулезнее, чем в ряде случаев в отношении обычного гражданского населения» [5]. Этот тезис подтверждает исследователь Н.П. Безносова в статье, посвященной переписям: «Сохранившиеся в Национальной архиве Республики Коми материалы переписи 1937 г. содержат многочисленные разночтения и правки, что объясняется незавершенностью обработки итоговых данных переписи. По существу, в нашем распоряжении имеются лишь несколько кратких таблиц о численности и национальном составе коренного населения. Перепись в спецпоселках была проведена органами НКВД, благодаря чему по спецпереселенцам мы имеем даже более подробные сведения, чем по коренным жителям» [6].

В своей последней крупной работе, опубликованной в 2014 г., В.Н. Земсков поясняет убыль спецпереселенцев-«бывших кулаков» на спецпоселениях в 1930-1931 гг.: «В 1929-1933 гг. в “кулацкую ссылку” было направлено более 2,1 млн. человек. К началу 1932 г. на учете числилось свыше 1,3 млн. спецпереселенцев, а было их направлено туда в 1930-1931 гг. немногим более 1,8 млн. Следовательно, за 1930-1931 гг. убыль составила около 0,5 млн. человек. Из указанной убыли число умерших составляло, по нашим оценкам, не более 200 тыс. (включая умерших при транспортировке. Количество родившихся в спецпереселенческих семьях в 1930-1931 гг. не представляется возможным установить даже приблизительно. Много людей умирало в пути следования. Отрицательное сальдо между рождаемостью и смертностью сохранялось в “кулацкой ссылке” до 1934 г. включительно» [7].

Новосибирский исследователь С.А. Красильников в статье, посвященной статистике «кулацкой ссылки» в начале 1930-х гг., называет данные, введенные в научный оборот В.Н. Земсковым по 1932-1940 гг., базовыми. Исследователь считает, что предположения В.Н. Земскова о том, что основная убыль в 1930-1931 гг. среди спецпереселенцев-«бывших кулаков» состояла из бежавших и умерших, были верными, оговаривая при этом, что половина бежавших задерживалась и возвращалась в комендатуры или задерживалась. В целом по стране общая убыль, по мнению исследователя, распределялась следующим образом: «Убыль складывалась в основном за счет бежавших (до 200 тыс. чел.) и умерших (около 160 тыс. чел.), далее шли переданные на иждивение родственникам и государству (более 65 тыс. чел.) и «неправильно высланные» (около 45 тыс. чел.)». Основная причина отсутствия полных статистических данных по спецпереселенцам в 1930-1931 гг., по мнению С.А. Красильникова, была в общих проблемах по управлению спецпоселениями и «организационном хаосе» $[8]$.

При анализе учета смертности и рождаемости в целом по СССР исследователями фиксируется большое расхождение в данных. В.Б. Жиромская отмечает, что учет смертей был неполным, особенно в сельской местности. Для сокрытия сильной убыли переписные листы во время переписи 1937 г. перераспределялись между регионами [9]. А. Блюм и М. Меспуле указывают на документы, включающие информацию о недоучете смертей до 80 \% [10]. Исследователь В.А. Исупов, рассматривая демографическую ситуацию первой половины XX в., отмечает: «Несмотря на стремление тоталитарного государства поставить под контроль не только жизнь, но и смерть каждого члена общества, значительная часть летальных исходов не регистрировалась. При чем недоучет смертей был значительно выше, чем недоучет рождений» [11]. В.А. Исупов полагает, что недоучет демографических событий был скорее правилом, чем исключением, и приводит данные, судя по которым погрешности в учете населения СССР составляли от 7,6 до 55 \% (табл. 1).

Таблий 1

Динамика рождаемости и смертности населения СССР в 1934-1938 г2. (в границах до 17.09.1939 2.)

\begin{tabular}{|c|c|c|c|c|c|c|}
\hline \multirow[b]{2}{*}{ Год } & \multicolumn{2}{|c|}{ Родилось, тыс. чел. } & \multirow[b]{2}{*}{$\begin{array}{c}\text { Поправка } \\
\text { на недоучет, \% }\end{array}$} & \multicolumn{2}{|c|}{ Умерло, тыс. чел. } & \multirow{2}{*}{$\begin{array}{c}\text { Поправка } \\
\text { на недоучет, \% }\end{array}$} \\
\hline & $\begin{array}{c}\text { По оценке } \\
\text { ЦУНХУ }\end{array}$ & $\begin{array}{c}\text { По современной } \\
\text { оценке }\end{array}$ & & $\begin{array}{c}\text { По оценке } \\
\text { ЦУНХУ }\end{array}$ & $\begin{array}{c}\text { По современной } \\
\text { оценке }\end{array}$ & \\
\hline 1934 & 3411 & 4780 & 40,1 & 2594 & 3410 & 31,4 \\
\hline 1935 & 4742 & 5249 & 10,7 & 2501 & 3882 & 55,2 \\
\hline 1936 & 5350 & 5589 & 4,5 & 2994 & 3223 & 7,6 \\
\hline 1937 & 6405 & 6549 & 2,2 & 2977 & 3557 & 19,5 \\
\hline 1938 & 6323 & 6516 & 3,1 & 2961 & 3483 & 17,6 \\
\hline
\end{tabular}

Источники: Исупов В.А. Демографические катастрофы и кризисы в России в первой половине ХХ века: Историкодемографические очерки. Новосибирск, 2000. С. 102, 112.

По 1932-1933 гг. фиксируется наибольший разрыв между уровнями рождаемости и смертности у гражданского населения СССР. По данным В.Б. Жиромской, в РСФСР смертность населения в 1933 г. превысила рождаемость на 215 тыс. чел. Исследователь отмечает, что «даже по неполным данным текущего учета умерло около 3 млн. человек». В 1934 г. был зафиксирован самый низкий уровень рождаемости за десятилетие (табл. 2). 
Таблища 2 Северный край, в состав которого с 1929 по 1936 г. Демографический баланс в РСФСР, тыс. чел. входили Архангельская, Вологодская и Коми автономная

\begin{tabular}{|l|c|c|c|}
\hline Годы & Рождаемость & Смертность & $\begin{array}{c}\text { Естественный } \\
\text { прирост }\end{array}$ \\
\hline 1929 & 4164,7 & 2111,1 & 2053,6 \\
\hline 1930 & 3598,5 & 1887,1 & 1711,4 \\
\hline 1931 & 3591,6 & 2031,6 & 1560,5 \\
\hline 1932 & 3359,1 & 2051,1 & 1308,0 \\
\hline 1933 & 2721,3 & 2927,1 & $-215,2$ \\
\hline 1934 & 2646,2 & 2004,4 & 641,9 \\
\hline 1935 & 3365,5 & 1874,9 & 1490,6 \\
\hline 1936 & 3676,3 & 2273,7 & 1402,7 \\
\hline 1937 & 4243,2 & 2193,6 & 2049,6 \\
\hline 1938 & 4159,8 & 2106,7 & 2053,1 \\
\hline 1940 & 4154,7 & 2142,0 & 2012,7 \\
\hline
\end{tabular}
области, был регионом, куда в 1930-1931 гг. было выслано самое большое число спецпереселенцев-«бывших кулаков» по сравнению с другими спецпереселенческими регионами, в целом за два года около 300 тыс. чел. С.А. Красильников приводит данные по Северному краю из Центрального архива ФСБ Российской Федерации, которые дают ответ на соотношение бежавших, умерших и освобожденных спецпереселенцев в 1930 г.: «Основным регионом размещения крестьян выступал Северный край, куда в феврале-марте было направлено 231 тыс. чел. (42 \% от общей численности крестьянской ссылки). Согласно сводке от 22 декабря 1930 г., в спецпоселках региона насчитывалось 104 тыс. чел. Убыль в 127 тыс. объяснялась

Источники: Жиромская В.Б. Демографическая история России в 1930-е гг. Взгляд в неизвестное. M., 2001. C. 12. следующими причинами: умерло 21,2 тыс. чел. (16,7 \%); детей, отправленных на родину к родственникам, $-35,4$ тыс. чел. $(28,0$ \%); возвращено на родину «неправильно высланных» 1,4 тыс. чел. (1,1 \%); признано «неправильно высланными», но оставлено в Северном крае «на свободное жительство» 26,5 тыс. чел. (20,8 \%); бежало 40 тыс. чел. (31,5 \%) (из них задержано 24 тыс. чел.); прочие причины убыли 2,4 тыс. чел. (1,9\%)» [12].

По данным В.Н. Земскова, в 1932 г. у спецпереселенцев в Северном крае умерло в 2,9 раза больше, чем родилось. Аналогичная ситуация сложилась во многих спецпереселенческих регионах, у размещенных в Южном Казахстане умерло больше, чем родилось в 4,4 раза, на Северном Кавказе - 4,0, в Западной Сибири - 3,9, на Алдане - 2,4, в Ленинградской обл. - 2,3, Восточной Сибири - 1,9, на Украине - 1,8, Дальнем Востоке 1,7 и у спецпереселенцев, проживавших в Горьковском крае - в 1,4 раза. В 1933 г. ситуация со смертностью усугубилась, превышение смертей над рождаемостью выглядело следующим образом: Северный край - в 9,6 раза, Белбалткомбинат НКВД - 5,1, Западная Сибирь - 4,8, Восточная Сибирь - 4,5, Дальний Восток - 4,1, Башкирия - 4,1, Горьковский край - 3,6, Алдан - почти в 2 раза и Ленинградская обл. - в 1,9 раза [13]. Так, по данным Сиблага ОГПУ, с июня 1931 г. по июнь 1932 г. в Нарыме у спецпереселенцев родилось 3841 чел., а умерло 25213 чел. Особенно велика была общая смертность с июня по сентябрь 1931 г. Ежемесячно умирало свыше 3,5 тыс. чел., среди умерших дети до одного года составляли в среднем 14 \%, а в отдельных комендатуpax значительно больше: в Анжерской - 43,5 \%, в Прокопьевской - 34 \% и т.д. [14].

Высокий уровень смертности был зафиксирован и в лагерях ГУЛАГа. Как отметили С.И. Глотик и В.В. Минаев, «крупные всплески смертности в лагерях» в 1930-е гг. наблюдались дважды: в 1933 г., что было вызвано голодом, и в 1938 г. из-за ужесточения репрессий. В 1932 г. число умерших в ИТЛ составило 13197 чел. (4,8 \% к среднесписочному составу), в 1933 г. - 67297 (15,3\%), в 1934 г. - 25187 (4,28 \%) [15].

Помимо отдела спецпоселений ОГПУ (НКВД) данные по смертности, например, в Коми автономной области (с 1936 г. - Коми АССР) фиксировались в 1930-е гг. Коми облисполкомом, Коми Обкомом ВКП(б), спецпоселковыми ЗАГСами, трестом «Комилес». Учет смертей и рождений не был систематизирован и имеет расхождения, например, за 1933 г. до 1,5 тыс. чел. По обобщенным данным Коми обкома (отчет о медикосанитарном обслуживании спецпереселенцев), в 1933 г. в спецпоселках умерло 1356 чел. [16]. По документам Облисполкома о «хозяйственном обустройстве» за первое полугодие 1933 г., среди спецпереселенцев Коми области умерло только детей 2563 чел. [17]. Эта цифра ставит под сомнение другие данные учета.

В переписке Коми обкома и КОО ОГПУ указывается, что за май-июнь 1933 г. только в спецпоселках одного Усть-Куломского района умерло 667 чел., смертность составила 10 \% к общему количеству спецпереселенцев в район [18]. Учитывая все эти данные, можно считать, что максимальное число умерших - 3095 - выглядит наиболее реальным. По данным Коми облисполкома, среди всех 10509 чел., умерших в Коми АССР в 1933 г. (без заключенных ИТЛ ГУЛАГа), спецпереселенцы составили 29 \% (3 095 чел.) (табл. 3).

По неполным данным органов ЗАГС (сведения не по всем месяцам) Ленского района Архангельской области, где в десяти спецпоселках на июль 1932 г. было учтено 5774 чел., в 1932-1933 гг. был зарегистрирован 1061 акт о регистрации смерти. Наибольшее число актов относилось к возрастным группам от 1 года до 10 лет - 317 чел. и от 11 до 20 лет - 179 чел., в возрасте от 1 до 21 года смертность составила 47 \% от общей смертности. В причинах смертности указывались истощение, понос, малокровие, сердечная слабость, воспаление легких, рахит, хронический бронхит, туберкулез легких и костей, «в дороге при переселении» [19]. 
Общей тенденцией естественного движения в спец(труд)поселках в 1930-е гг., было многократное превышение смертности над рождаемостью у спецпереселенцев до середины 1930-х гг. и постепенный рост рождаемости во второй половине 1930-х гг. Причинами высокого уровня смертности послужили неготовность регионов к массовым заселениям в короткие сроки, неблагоприятные условия жизни в спецпоселках, отсутствие нормального жилья, скудное снабжение продуктами питания, высокий уровень заболеваемости и эпидемии на фоне крайне недостаточного медицинского обслуживания.

Смертность спецпереселенцев-«бывших кулаков» в Коми автономной области в 1933 г.

\begin{tabular}{|l|c|}
\hline Учреждения, ведущие учет & Умерло спецпереселенцев \\
\hline ЗАГС & 2857 \\
\hline Коми облисполком & 3095 \\
\hline Коми обком ВКП(б) & 1356 \\
\hline
\end{tabular}

Составлено по: Архив Управления ЗАГСа Республики Коми. Дело № 06-23. Книга учета архивного фонда (о смерти); Спецпоселки Коми области: Сборник документов. Сыктывкар, 1997. С 253; НАРК. Ф. П-1. Оп. 2. Д. 461 . Л. 35.

В качестве примера общей ситуации на спецпоселениях в начале 1930-х гг. можно привести сообщение медработника и отчет коменданта спецпоселка в Коми автономной области в 1933 г. Помимо эпидемий тифа и цинги среди спецпереселенцев в начале 1930-х гг. наблюдались массовые случаи заболеваний на почве недоеданий, которые определялись как «голодные отеки», «опухания» или «безбелковые отеки». Фельдшер Иванов из Троицко-Печорского района в июле 1933 г. сообщал, что среди спецпереселенцев, работающих в лесу, и административно-высланных «появилось массовое заболевание на почве недоедания (голодные отеки) со смертельными исходами» [20]. Комендант спецпоселка Лесной Чер Усть-Куломского района в том же году о заболеваемости спецпереселенцев докладывал: «Имеется повышенная смертность населения, вследствие употребления в пищу различных суррогатов. Заболевания характеризуются следующими признаками: исхудание, отеки конечностей и лица, с последующими отеками живота, в конце болезни развивается расстройство желудочно-кишечного тракта с сильными поносами, после чего больные погибают. За май имеем 71 случай смерти. В основном гибнут трудоспособные и дети школьного возраста. На 15 июня по всему поселку числится в среднем 120 человек лежачих и слабоходячих. Имеются от 150 до 200 человек с отечностями и истощениями. Цинготных на 15 июня - 22 человека» [21]. По данным Коми Обкома ВКП(б), за май-июнь 1933 г. в спецпоселках Усть-Куломского района умерло 667 чел., смертность составила 10\% к общему количеству спецпереселенцев в районе [22]. По учету органов ЗАГС самый высокий уровень смертности в спецпоселках Коми области так же, как и по данным НКВД, приходится на 1933 г. (2 857 чел.), в 1934 г. уровень смертности снизился более чем в три раза (884 чел.) [23]. Основными причинами смерти в спецпоселках были заболевания, вызванные истощением организма. В актах о смерти чаще всего упоминались в качестве причин смерти рахит, порок сердца, грипп, туберкулез, понос, «воспаление мозговых оболочек мозга». По данным ОТСП ПП ОГПУ по Северному краю в 1933 г. на 79537 спецпереселенцев было зафиксировано 15355 случая смерти в спецпоселках: уровень смертности превосходил уровень рождаемости (1 606 случаев) в 9,5 раз. В СССР при общей численности 1142084 спецпереселенца, на 151601 умерших приходилось 17082 родившихся: уровень смертности превышал уровень рождаемости в 8,8 раз. В целом по СССР количество умерших спецпереселенцев составило 13 \% их общего числа, по Северному краю - 19%. В 1934 г. по Северному краю на 403 родившихся спецпереселенцев приходилось 2192 случая смерти, по СССР в спецпоселках 40012 умерших на 14033 родившихся (табл. 4) [24].

Таблица 4 В докладе УНКВД о состоянии по обслуживанию Данные по смертности и рождаемости в трудпереселенцев по Северному краю 1936 г. официально специоселках Северного края в 1932-1935 г2.

\begin{tabular}{|l|c|c|c|c|}
\hline \multicolumn{1}{|c|}{ Показатели } & 1932 г. & 1933 г. & 1934 г. & 1935 г. \\
\hline Населения на 1.01. & 112266 & 79537 & 71923 & 70774 \\
\hline Умерло & $\mathbf{4 6 6 4}$ & $\mathbf{1 5 3 5 5}$ & $\mathbf{2 1 9 2}$ & $\mathbf{1 1 9 4}$ \\
\hline$\%$ & 4,15 & 19,3 & 3,04 & 1,68 \\
\hline Родилось & $\mathbf{1 5 9 4}$ & $\mathbf{1 6 0 6}$ & $\mathbf{4 0 3}$ & $\mathbf{1 1 5 6}$ \\
\hline$\%$ & 1,49 & 2,03 & 0,56 & 1,63 \\
\hline
\end{tabular}
низкий уровень рождаемости в 1935 г. в сравнении с 1934 г. объяснялся низким уровнем брачности, причинами снижения смертности указаны улучшение условий в трудпоселках: «Рождаемость в отчетном году резко понизилась, создание новых семей идет слабо, случаи браков насчитываются единицами. Причина в частом перебрасывании на производственных работах с места на место. Молодежь Составлено по: Информационный центр МВД Респуб- воздерживается от создания своей семьи, не будучи галики Коми. Архивный отдел (далее - Архив МВД РК). рантированной в том, что они будут спокойно проживать Ф. 31. Оп. 1. Д. 6. Л. 6, 99.

с семьей на определенном месте производственных работ.

Кроме того, построение дома на поселках барачного типа не удовлетворяют потребности семейных трудпоселенцев, требуются значительные капиталовложения на ремонт их, а также у трудпоселенцев, желающих вступить в брак, отсутствуют денежные средства первое время на предмет приобретения крайне необходимого домашнего инвентаря. Смертность по сравнению с прошлыми годами резко уменьшилась, это объясняется улучшением материально-хозяйственных и бытовых условий на поселках, улучшением питания, путем соз- 
дания продовольственных баз - собственные огороды и т.п., а также проведением массовой разъяснительной профилактической работы» [25]. Следует отметить, что уровень регистрированной брачности, особенно в начале 1930-х гг. был низким. Например, по данным Коми облисполкма за 1932 г. в Сысольском районе на 5561 спецпереселенца было зарегистрировано пять браков, в Усть-Куломском районе на 8235 чел. - шесть браков, в Сыктывдинском - один брак на 5035 чел., в среднем - один брак на 1569 чел. [26].

Данные органов ЗАГС не являются полными, так как по некоторым спецпоселкам за определенные годы показатели отсутствуют. Тем не менее они отражают общую демографическую картину среди спецпересленцев, кроме того, данные ЗАГСов - единственный источник, содержащий данные о регистрируемой брачности спецпереселенцев. За 1933-1940 гг., по данным органов ЗАГС, в спецпоселках Коми АССР родилось 4567 чел. и умерло 6191 чел. Минимальный уровень рождаемости пришелся на 1933 г. - 139 чел. С 1936 г., как и по данным других учреждений, рождаемость превосходит смертность и сохраняется стабильное число рождений - около 700 чел. С 1936 по 1940 г. всего в спецпоселках Коми АССР было зарегистрировано 3637 рождений. С 1933 по 1940 г. в спецпоселках было зарегистрировано 988 браков и расторгнуто 56 (табл. 5).

Таблииа 5

Данные о рождаемости, смертности, регистрации и расторжении брака в трудпоселках Коми области (Коми АССР) в 1933-1940 22. по документам ЗАГС

\begin{tabular}{|l|c|c|c|c|c|c|c|c|c|}
\hline Показатели & 1933 г. & 1934 г. & 1935 г. & 1936 г. & 1937 г. & 1938 г. & 1939 г. & 1940 г. & Всего \\
\hline Рождаемость & 293 & 139 & 498 & 696 & 760 & 730 & 766 & 685 & 4567 \\
\hline Смертность & 2857 & 884 & 529 & 410 & 378 & 372 & 315 & 446 & 6191 \\
\hline Браки/ & $16 /$ & $64 /$ & $176 /$ & $188 /$ & $199 /$ & $144 /$ & $132 /$ & $69 /$ & $988 /$ \\
разводы & 2 & 7 & 13 & 15 & 3 & 7 & 4 & 5 & 56 \\
\hline
\end{tabular}

Составлено и подсчитано по: Управление ЗАГСа Республики Коми. Отдел учета, обработки и хранения документов. Дело № 06-23. Книга учета архивного фонда (о регистрации и расторжении брака); Книга учета архивного фонда (о рождении); Книга учета архивного фонда (о смерти).

По объединенным данным ОТСП ГУЛАГа НКВД СССР с 1932 по апрель 1937 г. у трудпоселенцев родилось 110225 чел., умерло 327466 чел. По неполным данным (отсутствие показателей по родившимся и умершим за I квартал 1941 г. по Казахской ССР, Коми АССР, Молотовской и Ивановской областям) за 19321941 гг. родилось 235229 чел., умерло 392081 чел., всего на 1 апреля 1941 г. насчитывалось 962470 трудпоселенцев [27]. Наблюдается уменьшение числа смертей к концу 1930-х гг. Исходя из обобщенных данных на период 1932-1937 гг. (І квартал) приходится 83,5 \% смертей, на период 1937 (III квартал) по I квартал 1941 г. 16,5 \%, по рождениям соотношение почти равное, с 1932 по 1937 гг. - 46,9 \% и с 1937 по 1941 г. - 53,1 \%. Естественная убыль с 1932 г. по I квартал 1941 г. (без данных по указанным регионам за I кв. 1941 г.) составила 156852 чел.

Во второй половине 1930-х гг. рождаемость спецпереселенцев постепенно начала расти, смертность снижалась. В частности, по данным НКВД Коми АССР, составленным в 1938 г., с 1936 г. рождаемость к 1938 г. превосходит смертность почти в два раза (табл. 6).

Таблица 6

Данные о рождаемости и смертности трудпереселенцев по данным ОТСП Коми АССР. Отчет за 1938 г.

\begin{tabular}{|l|c|c|c|c|}
\hline Показатели & 1935 г. & 1936 г. & 1937 г. & 1938 г. \\
\hline Численность* & 18706 & 18371 & 18797 & 18968 \\
\hline Рождаемость & 366 & 547 & 598 & 634 \\
\hline$\%$ & 2 & 3 & 3,16 & 3,33 \\
\hline Смертность & 438 & 414 & 373 & 338 \\
\hline$\%$ & 2,35 & 2,25 & 2 & 1,8 \\
\hline
\end{tabular}

*Без данных по тп. Новый Бор (Воркутлаг).

Источники: Архив МВД РК. Ф. 31. Оп. 1. Д. 9. Л. 1, 7.

В целом по рассматриваемым регионам Европейского Севера улучшение показателей естественного роста у спецпереселенцев фиксируется с 1935 г. Кризисный уровень естественной сверхубыли у спецпереселенцев относится к 1933 г., как по Еропейскому Северу, так и в СССР в целом. В 1932 г. умерло почти 90 тыс. чел., в 1933 г. - более 150 тыс., за четыре года (1932-1935 гг.) - более 300 тыс. спецпереселенцев. Смертность во много раз превышала рождаемость (в 1932 г. - в 5 раз, в 1933 г. в 9 раз) (табл. 7) [28].

В 1939-1940 гг. в регионах наблюдается благополучная ситуация естественного прироста у спецпереселенцев«бывших кулаков» (трудпоселенцев), высланных в 19301931 гг. Рождаемость превышает смертность, несмотря на снижение общего числа рождений (табл. 8). Ситуация меняется в 1941 г., когда в состав трудпоселенцев в Коми АССР и Архангельской области были включены трудпоселенцы, эвакуированные из прифронтовых территорий. Например, в Коми АССР с прибытием эвакуированных трудпоселенцев из Карело-Финской ССР уже со второго полугодия 1941 г. смертность вновь стала превышать рождаемость. 
Динамика движения трудпереселенцев в СССР

\begin{tabular}{|c|c|c|c|c|c|c|}
\hline \multirow{2}{*}{ Год } & \multicolumn{3}{|c|}{ CCCP } & \multicolumn{3}{|c|}{ Северный край* } \\
\hline & Наличие & Родилось & Умерло & Наличие & Родилось & Умерло \\
\hline 1931 & 1809024 & - & - & $285609 * *$ & & \\
\hline 1932 & 1317022 & 18053 & 89754 & 112266 & 1594 & 4664 \\
\hline 1933 & 1142084 & 17082 & 151601 & 79537 & 1606 & 15355 \\
\hline 1934 & 1072546 & 14033 & 40012 & 71923 & 403 & 2192 \\
\hline 1935 & 973693 & 26122 & 22173 & 67161 & 1156 & 1194 \\
\hline 1936 & 1017133 & 27617 & 19891 & 68809 & 1700 & 1443 \\
\hline 1937 & 916787 & 29036 & 17037 & Не ук. & 1844 & 1018 \\
\hline 1938 & 877651 & 31867 & 15961 & Не ук. & 1974 & 1036 \\
\hline 1939 & 938552 & 33716 & 16691 & 67517 & 2542 & 1031 \\
\hline
\end{tabular}

*За 1937-1939 гг. приведены суммарные данные по Архангельской и Вологодской областям, Коми АССР.

** Данные по: Коротаев В.И. На пороге демографической катастрофы: Принудительная колонизация и демографический кризис в Северном Крае в 30-е годы XX века. Архангельск, 2004. С. 37.

Составлено по: Государственный архив Российской Федерации (далее - ГАРФ). Ф. 9479. Оп. 1. Д. 89. Л. 213.

Таблича 8

Сведения о движении трудпоселенцев за 1939 и 1940 z2.

\begin{tabular}{|c|c|c|c|c|c|c|c|c|c|}
\hline & Показатели & $\begin{array}{c}\text { Арханг. } \\
\text { обл. }\end{array}$ & $\begin{array}{c}\text { Вологод. } \\
\text { обл. }\end{array}$ & $\begin{array}{l}\text { Коми } \\
\text { АССР }\end{array}$ & $\begin{array}{c}\text { п. Новый } \\
\text { Бор. Вор- } \\
\text { кутлаг. } \\
\text { Коми АССР }\end{array}$ & Всего & $\begin{array}{c}\text { \% от обще- } \\
\text { го числа чело- } \\
\text { век в трех ре- } \\
\text { гионах }\end{array}$ & $\begin{array}{c}\text { Всего } \\
\text { в СССР }\end{array}$ & $\begin{array}{c}\text { \% от об- } \\
\text { щего числа } \\
\text { человек }\end{array}$ \\
\hline \multirow[t]{4}{*}{1.} & Состоит на 1.01 .39 & & & & & & & & \\
\hline & Человек & 35386 & 8641 & 18968 & 1303 & 64298 & & 938552 & \\
\hline & Родилось & 1515 & 341 & 686 & 3 & 2545 & 3,9 & 33716 & 3,6 \\
\hline & Умерло & 576 & 141 & 314 & - & 1031 & 1,6 & 16691 & 1,8 \\
\hline \multirow[t]{4}{*}{2.} & Состоит на 1.01 .40 & & & & & & & & \\
\hline & Человек & 40053 & 9827 & 18941 & $1615^{*}$ & 70436 & & 997513 & \\
\hline & Родилось & 1168 & 340 & 475 & 68 & 2051 & 2,9 & 32732 & 3,3 \\
\hline & Умерло & 647 & 156 & 302 & 35 & 1140 & 1,6 & 16401 & 1,6 \\
\hline \multirow[t]{4}{*}{3.} & Состоит на 1.01.41 & & & & & & & & \\
\hline & Человек & 36597 & 9979 & 17492 & 1610 & 65678 & & 930221 & \\
\hline & Родилось & 849 & 339 & 400 & 146 & 1734 & 2,6 & 25624 & 2,8 \\
\hline & Умерло & 532 & 172 & 389 & 69 & 1162 & 1,8 & 15365 & 1,7 \\
\hline
\end{tabular}

* Сведения за третий квартал.

Составлено и подсчитано по: ГАРФ. Ф. 9479. Оп. 1сч. Д. 89. Л. 216, 217, 61.

В целом следует сказать, что наиболее кризисная ситуация для спецпереселенцев складывалась в первые годы высылки. Вследствие отсутствия налаженной инфраструктуры спецпоселков, спецпереселенцы испытывали недостаток продуктов питания, одежды, обуви, медикаментов. Такая ситуация вела к голоду и эпидемиям в спецпоселках и в итоге к высокому уровню смертности. Выравнивание показателей смертности и рождаемости и выход на положительные показатели естественного движения происходит через пять и более лет, эта тенденция сохранится и для других групп спецпереселенцев в 1940-е гг., независимо от массовости и периода высылки на спецпоселения. Уровень рождаемости и смертности из всех показателей отражает уровень адаптации высланных к условиям на спецпоселениях наиболее явно.

Сохранившиеся архивные данные по естественному движению спецпереселенцев являются во многом отрывочными, неравномерными по фактологической наполняемости по периодам и регионам, имеют статистические расхождения, особенно по периоду первой половины 1930-х гг., но, на наш взгляд, неполнота данных не говорит об их недостоверности. Работа над новыми историческими источниками позволит в дальнейшем уточнить и систематизировать спорные данные по рождаемости и смертности спецпереселенцев, в том числе по периоду 1930-1931 гг. 


\section{Источники и литература}

1. Кириллов В.М. Историография истории репрессий в СССР и на Урале // Власть и общество: Сб. науч. трудов преп. ист. фак-та. Нижний Тагил, 1996. С. 77.

2. Славко Т.И. Кулацкая ссылка на Урале 1930-36 гг. М., 1995. С. 7.

3. Земсков В.Н. Заключенные, спецпоселенцы, ссыльнопоселенцы, ссыльные и высланные. (Статистикогеографический аспект) // История СССР. 1991. № 5. С. 151-165.

4. Максудов С. О публикациях в журнале «Социс» // Социологические исследования. 1995. № 9. С. 114-118.

5. Земсков В.Н. Заключенные, спецпоселенцы, ссыльнопоселенцы, ссыльные и высланные. (Статистикогеографический аспект) // История СССР. 1991. № 5. С. 151-165.

6. Безносова Н.П. Новые документы по статистике населения Коми АССР за 1937-1989 гг. // Историческая демография. Научный журнал. 2018. № 1 (21). С. 95.

7. Земсков В.Н. Сталин и народ. Почему не было восстания. М., 2014. С. 11.

8. Красильников С.А. Статистика начального периода и депортаций крестьянства в 1930-1931 гг.: возможности и ограничения для исторической реконструкции // Идеи и идеалы. 2015. № 4 (26). Т. 2. С. 33-41.

9. Жиромская В.Б. Демографическая история России в 1930-е гг. Взгляд в неизвестное. М., 2001. С. 13.

10. Блюм А., Меспуле М. Бюрократическая анархия. Статистика и власть при Сталине. М., 2006. С. 94.

11. Исупов В.А. Демографические катастрофы и кризисы в России в первой половине XX века: Историкодемографические очерки. Новосибирск, 2000. С. 112.

12. Красильников С.А. Статистика начального периода и депортаций крестьянства в 1930-1931 гг.: возможности и ограничения для исторической реконструкции // Идеи и идеалы. 2015. № 4 (26), т. 2. С. 33-41.

13. Земсков В.Н. «Кулацкая ссылка» в 30-е годы // http://stalinism.ru/kollektivizatsiya/kulatskaya-ssyilka-v30-e-godyi.html

14. Гущии Н.Я. Раскулачивание в Сибири (1928-33 гг.): социально-экономические и демографические последствия // Гуманитарная наука в России: соросовские лауреаты. М., 1996. С. 51.

15. Глотик С.И, Минаев В.В. Население и власть: Очерки демографической истории СССР 1930-х годов. M., 2004. C. 161.

16. Национальный архив Республики Коми (далее - НАРК). Ф.П.-1. Оп. 1. Д. 461. Л. 35.

17. НАРК. Ф. Р-3. Оп. 1. Д. 2432. Л. 1.

18. НАРК. Ф. П-1. ОП. 2. Д. 970. Л. 40.

19. Угрюмов Б.А. Судьба крестьянская. Краткий очерк истории Ленской деревни. СПб., 2005. Л. 27, 28.

20. НАРК. Ф.Р.-3. Оп. 1. Д. 2428. Л. 10.

21. НАРК. Ф.Р.-3. Оп. 1. Д. 2428. Л. 29.

22. НАРК. Ф.П.-1. ОП. 2. Д. 970. Л. 40.

23. НАРК.Ф.Р-140. Оп. 2. Д. 279. Л. 1, 3

24. Земсков В.Н. Спецпоселенцы в СССР, 1930-1960. М., 2005. С. $20-42$.

25. Архив МВД РК. Ф. 31. Оп. 1. Д. 6. Л. 1. 5,6

26. НАРК. Ф.Р.-3. Оп. 1. Д. 2375. Л. 160; Д. 2419. Л. 117.

27. ГАРФ. Ф. 9479. Оп. 1. Д. 89. Л. 213, 221.

28. Ивниикий Н.A. Коллективизация и раскулачивание: (Начало 30-х годов). С. 270-271.

29. Коротаев В.И. На пороге демографической катастрофы: Принудительная колонизация и демографический кризис в Северном Крае в 30-е годы XX века. Архангельск, 2004. С. 37. 


\title{
А.П. Обедков*
}

\section{Сдвиги в размещении и тенденции расселения населения Республики Коми в 1920-2020 гг.}

\begin{abstract}
В статье дан анализ вековой динамики и причины сдвигов в размещении населения Республики Коми в период с 1920 по 2020 г. Рассмотрены изменения территориальной структуры и выявлены тенденции населения региона в разрезе низовых административных районов и подзон Дальнего, Среднего и Ближнего Севера.
\end{abstract}

Ключевые слова: численность населения, территориальная структура населения, сдвиги в размещении населения, тенденции расселения населения, Республика Коми

\section{A.P. Obedkov}

\section{Shifts in the location and trends in the settlement of the population of the Komi Republic in 1920-2020}

The analysis of the age-old dynamics and the reasons for the shifts in the population distribution of the Komi Republic in the period from 1920 to 2020 is given. Changes in the territorial structure are considered and trends in the population of the region in the context of the lower administrative regions and subzones of the Far, Middle and Near North are revealed.

Key words: population size, territorial structure of the population, shifts in the placement of the population, trends in the settlement of the population, the Republic of Komi

Формирование демографического потенциала региона представляет собой комплексный социально-экономический процесс, отражающий изменение численности и режима воспроизводства, структуры и размещения населенияв. На процесс формирования территориальной структуры населения территории откладывают отпечаток зональные закономерности и региональные физико-географические условия, характер использования природно-ресурсного потенциала территории и сложившаяся на его основе специализация регионального хозяйственного комплекса, направленность миграционных процессов и темпы урбанизации, степень урбанизированности и заселенности территории. При этом особенности формирования территориальной структуры региона в условиях Севера имеют свою специфику, которая хорошо просматривается на примере Республики Коми как типичного северного региона с длительной историей хозяйственного освоения и заселения.

По данным переписи населения 1920 г., в границах территорий, вошедших в состав АО Коми (Зырян), насчитывалось 179,8 тыс. чел. Средняя плотность населения АО Коми (Зырян) составляла 0,5 чел. на 1 кв. версту. При этом население крайне неравномерно размещалось на территории Коми АО. На долю самого небольшого по площади Сысольского уезда, занимающего 8,5 \% территории, приходилось 36,9\% всего населения при средней плотности населения 2,1 чел. на 1 кв. версту. Далее по людности шли Усть-Куломский и Усть-Вымский уезды, на долю которых приходилось соответственно 27,1 и 23,1 \% всего населения. Самым малолюдным был ИжмоПечорский уезд. Занимая 50,1 \% территории АО Коми (Зырян), он концентрировал всего 12,3 \% всего населения при средней плотности населения 0,1 чел. на 1 кв. версту (табл. 1).

С 1922 по 1928 г. территория АО Коми (Зырян) в административном отношении была разделена на четыре уезда, в которых подавляющее большинство составляли сельские жители. Однако при этом уезды существенно различались друг от друга по занимаемой площади, численности и средней плотности населения. Согласно официальным итогам Первой Всесоюзной переписи населения 1926 г., в пределах действовавших на момент переписи административных границ АО Коми (Зырян) насчитывалось 207314 чел. Самым населенным в Коми АО был самый небольшой по площади Сысольский уезд. В его границах проживали все горожане и 35,4 \% всех жителей автономной области. Следующими по людности были Усть-Куломский и Усть-Вымский уезды, на долю

\footnotetext{
* Обедков Анатолий Павлович (Сыктывкар) - кандидат географических наук, старший научный сотрудник сектора историко-демографических и историко-географических проблем Российского Севера Института языка, литературы и истории Коми НЦ УрО РАН, ObedkovAР@gmail.com.
} 
которых приходилось соответственно 27,2 и 22,6\% всего населения Коми автономной области. В самом большом по площади Ижмо-Печорском уезде, занимавшем половину территории автономной области, проживало всего $16,1 \%$ жителей региона [1].

Таблииа 1

Численность и структура городского и сельского населения
автономной области Коми (зырян) по переписи населения 1920 2.
ве и границах административно-территориального деления 1922-1928 22.)

\begin{tabular}{|l|c|c|c|c|c|}
\hline \multicolumn{1}{|c|}{ Уезды } & $\begin{array}{c}\text { Численность } \\
\text { наличного } \\
\text { населения, чел. }\end{array}$ & $\begin{array}{c}\text { Доля в общей } \\
\text { численности } \\
\text { населения, } \%\end{array}$ & $\begin{array}{c}\text { Удельный вес } \\
\text { сельского } \\
\text { населения, \% }\end{array}$ & $\begin{array}{c}\text { Площадь, } \\
\text { кв. вёрсты }\end{array}$ & $\begin{array}{c}\text { Доля в общей } \\
\text { площади, \% }\end{array}$ \\
\hline Всего & 179847 & 100 & 97 & 378355 & 100 \\
\hline Сысольский & 66443 & 36,9 & 8,1 & 32034 & 8,5 \\
\hline Ижмо-Печорский & 22000 & 12,3 & 100 & 189614 & 50,1 \\
\hline Усть-Вымский & 42655 & 23,1 & 100 & 60869 & 16,1 \\
\hline Усть-Куломский & 48749 & 27,1 & 100 & 95838 & 25,3 \\
\hline
\end{tabular}

Источник: ЦГА Республики Коми. Ф. Р-140. Оп. 2. Ед. хр. 215. С. 14.

В последующие годы итоги Всесоюзной переписи населения 1926 г. корректировались в связи с реформированием административно-территориального деления в 1929-1939 гг. и изменения внешних границ АО Коми (Зырян) в результате обмена территориями с соседними Архангельской и Вятской губерниями. При образовании в 1929 г. Северного края и Ненецкого национального округа в его состав из автономной области Коми (Зырян) были переданы территории Большеземельской тундры с Пустозёрской волостью и Тельвисочно-Ненецким районом, в пределах которых было учтено около 3 тыс. чел. кочевого населения. В том же году Коми автономная область получила из Архангельской губернии территории Пысского сельсовета (1,4 тыс. чел.) Койнасской волости Мезенского уезда, Усть-Цилемскую волость (11,9 тыс. чел.) и Ермицкий сельсовет (1,1 тыс. чел.) Пустозёрской волости Печорского уезда, а из Вятской губернии - Слудскую волость (6,1 тыс. чел.) Халтуринского уезда. В результате этих административно-территориальных преобразований площадь Коми автономной области уменьшилась на 104,5 тыс. кв. км и составила 375 тыс. кв. км, численность ее населения увеличилась на 17,7 тыс. чел. [2].

Согласно данным Коми областного статистического отдела, пересчитанная численность населения АО Коми (Зырян) в новых границах достигла 234,9 тыс. чел. [3]. Несколько иные данные пересчета представлены в статистическом сборнике, опубликованном в 1930 г. в краевом центре Северного края городе Архангельск. Согласно данным архангельского статистического сборника, общая численность населения Коми АО в новых границах составила 226357 чел. [4].

По данным первой Всесоюзной переписи населения 1926 г., большинство жителей АО Коми (Зырян) концентрировалось в районах Ближнего Севера, на долю которых приходилось 73,4 \% (165,6 тыс. чел.) всего населения, 72,2 \% сельского населения и все горожане региона. На Среднем Севере проживало 23,6 \% (53,3 тыс. чел.), а на малолюдном в то время Дальнем Севере - всего 3\% (6,8 тыс. чел.) населения Коми АО.

В период между Всесоюзными переписями населения 1926 и 1939 гг. численность населения Коми АССР увеличилась в 1,4 раза (с 224,9 до 320,3 тыс. чел.). Рост численности населения способствовал повышению средней плотности населения до 0,8 чел. на 1 кв. км и плотности сельского населения - до 0,7 чел. на 1 кв. км. При этом с 1926 по 1939 г. средняя плотность населения республики увеличилась в 1,6 раза, а плотность сельского населения - в 1,8 раза.

По мере роста территории активного хозяйственного освоения и совершенствования административнотерриториального деления Коми АССР к концу 1930-х гг. изменилась территориальная структура населения. При средней людности района в 24,5 тыс. чел. только один район (Усть-Вымский) имел численность населения более 40 тыс. чел., три (Ижемский, Сыктывдинский, Усть-Куломский) - от 30,1 до 40 тыс. чел., два (Сысольский, Усть-Усинский) - от 20,1 до 30 тыс. чел. и пять (Летский, Прилузский, Сторожевский, Троицко-Печорский, Удорский) - от 10,1 до 20 тыс. чел. В пяти самых людных районах республики проживало 174,3 тыс. чел., или 54,6 \% всего населения. Суммарно во всех 12 районах проживало 293,7 тыс. чел., что составляло 92,1\% населения республики. Подавляющее большинство населения было сельскими жителями, при этом в 10 из 12 районов на их долю приходилось 100\% всего населения. Помимо Сыктывкара, городское население имелось лишь в Ижемском и Сыктывдинском районах. Удельный вес городского населения в этих районах составлял соответственно всего 8,1 и 3,3 \%. Самыми людными центрами административных районов были Усть-Уса (4,3 тыс. чел.) и Усть-Цильма (4,2 тыс. чел.), а самыми малолюдными - Визинга (1,1 тыс. чел.) и Летка (1,2 тыс. чел.). По уровню концентра- 
ции населения в административном центре района выделялись Усть-Цилемский (25,6 \%) и Усть-Усинский $(20,3 \%)$, а также Усть-Куломский (11,3\%) и Троицко-Печорский (10,6 \%) районы. В 12 административных центрах районов проживало 29,1 тыс. чел., или $10 \%$ сельского населения республики. В столице Коми АССР городе Сыктывкаре, который в то время был единственным городом в республике, проживало 25,3 тыс. чел., что составило 86,7 \% численности городского населения. Помимо Сыктывкара, городское население имелось лишь в Ижемском и Сыктывдинском районах. Удельный вес городского населения в этих районах составлял соответственно всего 8,1 и 3,3\% [5].

В довоенный период наиболее заселенными оставались районы юго-западной части республики, где проживало около 2/3 всего населения. В эти годы началось выборочное промышленное освоение районов центральной и северо-восточной частей Коми АССР. На начало 1939 г. большинство жителей республики проживало в пределах Ближнего Севера, на долю которого приходилось 73,2 \% (234,5 тыс. чел.) всего населения. Районы Среднего Севера концентрировали уже 20,2 \% (64,7 тыс. чел.) демографического потенциала Коми АССР. По-прежнему слабо заселенными оставались территории Дальнего Севера. В период между переписями населения 1926 и 1939 гг. абсолютная численность проживающих на Дальнем Севере увеличилась в 3,1 раза до 21,1 тыс. чел., а удельный вес в населении республики - в 2,2 раза до 6,6 \%.

Численность всего населения Коми АССР только в течение 1941 г. увеличилась на 38,1 тыс. чел. (или на 11,2\%), после чего происходило непрерывное снижение численности населения. С 1942 по 1945 г. население Коми АССР сократилось на 103,1 тыс. чел., или в 1,4 раза. Таким образом, в целом за весь период с 1941 по 1945 г. в Коми АССР произошло сокращение численности населения главным образом вследствие превышения естественной убыли населения над миграционным приростом [6].

Наиболее кардинальные изменения в динамике и территориальной структуре населения Коми АССР произошли в послевоенное десятилетие. Рост масштабов добычи топливно-энергетических ресурсов, сопровождавшийся созданием новых предприятий и центров топливной промышленности, потребовал активизации железнодорожного строительства. С 1947 по 1959 г. велось сооружение примыкающих к Печорской железнодорожной магистрали железнодорожной ветки Чум - Лабытнанги, а с 1958 по 1961 г. - Микунь - Сыктывкар. В эти годы были образованы города и рабочие поселки в северных и центральных районах республики, связанных с добычей и первичной переработкой нефти, газа и угля. По данным Всесоюзной переписи населения 1959 г., численность населения Сыктывкара достигла 64,5 тыс. чел., Воркуты - 55,7 тыс., Инты - 45,1 тыс., Ухты - 36,2 тыс., Печоры - 30,6 тыс., Сосногорска - 15,8 тыс., Микуни - 11,3 тыс. чел. В местах сосредоточения городских населенных пунктов вокруг Сыктывкара, Воркуты, Ухты и Печоры наметились контуры групповых систем населенных мест и городских протоагломераций.

1950-е гг. стали десятилетием наиболее динамичного демографического развития республики за всю историю ее существования. В результате высоких темпов роста населения в 1950 -е гг. число жителей Коми АССР увеличилось в 1,9 раза (с 423,3 тыс. до 815,8 тыс. чел.). При этом средняя плотность населения Коми АССР достигла 2 чел. на 1 кв. км, а плотность сельского населения - 0,8 чел. на 1 кв. км.

Наметившаяся в довоенный период тенденция активного заселения ранее малолюдных, слабоосвоенных и необжитых северных территорий республики получила дальнейшее развитие в послевоенный период. В межпереписной период с 1939 по 1959 г. число низовых административных районов с городским населением увеличилось в 4 раза (с 3 до 12). По данным переписи населения 1959 г., самым людным низовым административным районом был Воркутинский горсовет (175,9 тыс. чел.). На втором месте по численности населения находился Сыктывкарский горсовет (74,5 тыс. чел.), на третьем - Печорский район (66,5 тыс. чел.). В трех самых населенных низовых административных районах проживало 38,8 \% всего населения республики, из них 21,6\% составляло население Воркутинского горсовета. Из остальных 19 низовых административных районов пять (Интинский и Ухтинский горсоветы, Железнодорожный, Усть-Вымский и Ухтинский районы) имели людность в пределах от 40,1 до 50 тыс. чел., один (Троицко-Печорский район) - от 30,1 до 40 тыс. чел., пять (Ижемский, Интинский, Прилузский, Сыктывдинский и Сысольский районы) - от 20,1 до 30 тыс. чел. и восемь (Койгородский, Корткеросский, Летский, Помоздинский, Сторожевский, Удорский, Усть-Куломский и Усть-Цилемский районы) - от 10,1 до 20 тыс. чел. В 14 из 22 низовых административных районов республики преобладало сельское население, а в 10 из них полностью отсутствовало городское население. В 14 селах, выполняющих роль административных центров районов, проживало 40,1 тыс. чел., что составило 12,1 \% сельского населения республики. По данным переписи населения 1959 г., самыми людными из них были Усть-Цильма (4,4 тыс. чел.), Усть-Кулом (4,1 тыс.) и Выльгорт (4,1 тыс.), а самыми малолюдными - Помоздино (1 тыс.), Койгородок (1,8 тыс.) и Корткерос (1,9 тыс. чел.). По уровню концентрации населения в административном центре района выделялись Усть-Цилемский $(23,7 \%)$ и Усть-Куломский $(22,4 \%)$ районы. Еще в шести районах (Летский, Прилузский, Сторожевский, Сыктывдинский, Сысольский и Удорский) людность административного центра варьировалась в пределах от 15 до 20 \% в населении района (табл. 2). 
В межпереписной период с 1939 по 1959 г. более динамично развивался демографический потенциал северных территорий. В этот период численность населения Дальнего Севера увеличилась в 11,9 раз (с 21,1 до 251,3 тыс. чел.), Среднего Севера - в 3,7 раза (с 64,7 до 236,5 тыс.), а Ближнего Севера - в 1,4 раза (с 234,5 до 328 тыс.). Это вызвало кардинальные изменения в территориальном распределении населения республики в разрезе трех подзон Севера. Уже с середины 1950-х гг. в общей численности населения Коми АССР стали преобладать районы Среднего и Дальнего Севера. По данным переписи населения 1959 г., на долю Дальнего Севера приходилось 30,8 \% всего населения, 49,3 \% городского населения и 3,8 \% сельского населения Коми АССР. В районах Среднего Севера проживали 29 \% всего населения, 27,1 \% городского населения и 31,6 \% сельского населения. Удельный вес районов Ближнего Севера в общей численности населения республики снизился с 73,2 до 40,2 \%, а городского населения - с 90,8 до 23,6 \%. Несмотря на снижение доли проживающих в пределах Ближнего Севера, эта подзона по-прежнему оставалась наиболее населенной в республике и основной территорией концентрации сельского населения (64,6 \%).

В 1960-1970-е гг. дальнейшее развитие получили демографические тенденции предыдущего периода. Рост численности городского населения в эти десятилетия был связан прежде всего с началом разработки крупных месторождений нефти и газа Тимано-Печорской нефтегазоносной провинции, строительством и эксплуатацией магистральных трубопроводов и предприятий первой очереди Сыктывкарского лесопромышленного комплекса. В эти годы в регионе сооружались ответвления Печорской железнодорожной магистрали Микунь - Вендинга (1961-1974 гг.), Сосногорск - Троицко-Печорск (1963-1977 гг.) и Сыня - Усинск (1974-1980 гг.). Их ввод в эксплуатацию способствовал ускорению процесса хозяйственного освоения природно-ресурсного потенциала территории и перераспределению населения в районы центральной и северо-восточной частей республики. В свою очередь, улучшение транспортных условий региона обусловило возникновение и развитие новых рабочих поселков и городов, промышленных центров и хозяйственных узлов, баз и трасс хозяйственного освоения территории.

Численность и структура городского и сельского населения Коми АССР Таблица 2 по данным Всесоюзной переписи населения 1959 2.

\begin{tabular}{|c|c|c|c|c|c|c|c|}
\hline \multirow{2}{*}{$\begin{array}{c}\text { Низовые } \\
\text { административные } \\
\text { районы }\end{array}$} & \multirow{2}{*}{$\begin{array}{c}\text { Всё } \\
\text { население, } \\
\text { чел. }\end{array}$} & \multicolumn{2}{|c|}{ В том числе } & \multicolumn{2}{|c|}{$\begin{array}{c}\text { Доля в общей числен- } \\
\text { ности населения, \% }\end{array}$} & \multicolumn{2}{|c|}{$\begin{array}{c}\text { Людность } \\
\text { административного центра }\end{array}$} \\
\hline & & $\begin{array}{l}\text { Городское } \\
\text { население }\end{array}$ & $\begin{array}{l}\text { Сельское } \\
\text { население }\end{array}$ & $\begin{array}{l}\text { Городское } \\
\text { население }\end{array}$ & $\begin{array}{l}\text { Сельское } \\
\text { население }\end{array}$ & $\begin{array}{l}\text { Кол-во че- } \\
\text { ловек }\end{array}$ & $\begin{array}{c}\text { В \% ко всему } \\
\text { населению }\end{array}$ \\
\hline Коми АССР, всего & 815799 & 484039 & 331760 & 59,3 & 40,7 & 64461 & 7,9 \\
\hline \multicolumn{8}{|l|}{ Горсоветы: } \\
\hline Сыктывкарский & 74469 & 74469 & - & 100 & - & 64461 & 86,6 \\
\hline Воркутинский & 175857 & 175857 & - & 100 & - & 55668 & 31,7 \\
\hline Интинский - г. Инта & 45136 & 45136 & - & 100 & - & 45136 & 100 \\
\hline Ухтинский & 48030 & 48030 & - & 100 & - & 36154 & 75,3 \\
\hline \multicolumn{8}{|l|}{ Районы: } \\
\hline Железнодорожный & 43277 & 22294 & 20983 & 51,5 & 48,5 & 13706 & 31,7 \\
\hline Ижемский & 22026 & - & 22026 & - & 100 & 2495 & 11,3 \\
\hline Интинский & 21224 & 17542 & 3682 & 82,7 & 17,3 & - & - \\
\hline Койгородский & 19356 & 3750 & 15606 & 19,4 & 80,6 & 1759 & 9,1 \\
\hline Корткеросский & 14970 & - & 14970 & - & 100 & 1862 & 12,4 \\
\hline Летский & 14703 & - & 14703 & - & 100 & 2361 & 16,1 \\
\hline Печорский & 66521 & 48295 & 18226 & 72,6 & 27,4 & 30586 & 46 \\
\hline Помоздинский & 16804 & - & 16804 & - & 100 & 994 & 5,9 \\
\hline Прилузский & 21502 & - & 21502 & - & 100 & 3343 & 15,5 \\
\hline Сторожевский & 16314 & - & 16314 & - & 100 & 2499 & 15,3 \\
\hline Сыктывдинский & 26455 & 2120 & 24335 & 8 & 92 & 4068 & 15,4 \\
\hline Сысольский & 20554 & - & 20554 & - & 100 & 3565 & 17,3 \\
\hline Троицко-Печорский & 35187 & 5311 & 29876 & 15,1 & 84,9 & 3607 & 10,3 \\
\hline Удорский & 13592 & - & 13592 & - & 100 & 2410 & 17,7 \\
\hline Усть-Вымский & 41989 & 11347 & 30642 & 27 & 73 & 2655 & 6,3 \\
\hline Усть-Куломский & 18195 & - & 18195 & - & 100 & 4082 & 22,4 \\
\hline Усть-Цилемский & 18667 & - & 18667 & - & 100 & 4428 & 23,7 \\
\hline Ухтинский & 40971 & 29888 & 11083 & 72,9 & 27,1 & - & - \\
\hline
\end{tabular}

Составлено и рассчитано по: Всесоюзная перепись населения на 15 января 1959 г. Численность наличного населения городов и районов по республикам, краям и областям РСФСР (www.demoscope.ru/weekly/ssp/rus59_reg1.php) 
В период между переписями населения 1959 и 1970 гг. численность населения Коми АССР увеличилась в 1,2 раза (с 815,9 до 964,8 тыс. чел.). Рост численности населения способствовал повышению средней плотности населения до 0,8 чел.на 1 кв. км и плотности сельского населения - до 0,7 чел. на 1 кв. км. Вследствие увеличения численности городского и сельского населения на начало 1970 г. общая средняя плотность населения увеличилась до 2,3 чел. на 1 кв. км, а плотность сельского населения достигла максимальной величины за всю историю республики - 0,9 чел. на 1 кв. км. В этот период наиболее динамично развивался демографический потенциал низовых административных районов, на территории которых активизировалось развитие промышленности, строительства и транспорта. В 1970 г. в 10 низовых административных районах произошло увеличение численности населения, а в восьми снижение людности. В межпереписной период в 1,9 раза увеличилась численность населения Сыктывкарского горсовета, где в эти годы велось масштабное строительство крупнейших предприятий республики - Сыктывкарского лесопромышленного комплекса и Сыктывкарской фабрики нетканых материалов. В рассматриваемый период в 1,7 раза увеличилось население Ухтинского горсовета, в 1,5 раза - Удорского района, на $26,4 \%$ - Усть-Куломского района, на $18,6 \%$ - Ижемского района, на $17,5 \%$ - Печорского горсовета и Печорского района, на 7,3\% - Сысольского района, на 5,2\% - Воркутинского горсовета и на 1,6\% - Корткеросского района. Между тем в эти годы на $16,5 \%$ сократилось население Троицко-Печорского района, на 12,6\% - Княжпогостского района, на 9,9\% - Койгородского района, на 7,4\% - Интинского горсовета, на 1,9\% - Усть-Вымского района, на 1,3\% - Усть-Цилемского района, на 1,2\% - Прилузского района и на $0,6 \%$ - Сыктывдинского района.

По данным переписи населения 1970 г., самым людным низовым административным районом республики оставался Воркутинский горсовет (184,9 тыс. чел.). На втором месте по численности населения находился Ухтинский горсовет район (151,4 тыс. чел.), на третьем - Сыктывкарский горсовет (138,3 тыс. чел.), на четвертом месте - Интинский горсовет (61,5 тыс. чел.). В этих четырех самых населенных низовых административных районах концентрировалось $55,6 \%$ всего населения республики, из них 19,2\% составляло население Воркутинского горсовета. Из остальных 14 низовых административных районов три (Печорский горсовет, Усть-Вымский и Усть-Куломский районы) имели людность в пределах от 40,1 до 45 тыс. чел., четыре (Княжпогостский, Корткеросский, Печорский и Прилузский районы) - от 30,1 до 40 тыс. чел., пять (Ижемский, Сыктывдинский, Сысольский, Троицко-Печорский и Удорский районы) - от 20,1 до 30 тыс. чел. и два (Койгородский и Усть-Цилемский районы ) - от 10,1 до 20 тыс. чел. (табл. 3).

Таблица 3

Численность и структура городского и сельского населения Коми АССР по данным Всесоюзной переписи населения 1970 г.

\begin{tabular}{|c|c|c|c|c|c|c|c|}
\hline \multirow{2}{*}{$\begin{array}{c}\text { Низовые } \\
\text { административные } \\
\text { районы }\end{array}$} & \multirow{2}{*}{$\begin{array}{c}\text { Всё } \\
\text { население, } \\
\text { чел. }\end{array}$} & \multicolumn{2}{|c|}{ В том числе } & \multicolumn{2}{|c|}{$\begin{array}{c}\text { Доля в общей } \\
\text { численности населения, \% }\end{array}$} & \multicolumn{2}{|c|}{$\begin{array}{l}\text { Людность админи- } \\
\text { стративного центра }\end{array}$} \\
\hline & & $\begin{array}{l}\text { Городское } \\
\text { население }\end{array}$ & $\begin{array}{c}\text { Сельское } \\
\text { население }\end{array}$ & $\begin{array}{l}\text { Городское } \\
\text { население }\end{array}$ & $\begin{array}{l}\text { Сельское } \\
\text { население }\end{array}$ & Человек & $\begin{array}{c}\text { В \% ко всему } \\
\text { населению }\end{array}$ \\
\hline Коми АССР, всего & 964802 & 597416 & 367386 & 61,9 & 38,1 & 125088 & 13 \\
\hline \multicolumn{8}{|l|}{ Горсоветы: } \\
\hline Сыктывкарский & 138318 & 137210 & 1108 & 99,2 & 0,8 & 125088 & 90,4 \\
\hline Воркутинский & 184945 & 182779 & 2166 & 98,8 & 1,2 & 89742 & 48,5 \\
\hline Интинский & 61496 & 56127 & 5369 & 91,3 & 8,7 & 50178 & 81,6 \\
\hline Печорский & 40826 & 37803 & 3023 & 92,6 & 7,4 & 37803 & 92,6 \\
\hline Ухтинский & 151412 & 123393 & 28019 & 81,5 & 18,5 & 62983 & 41,6 \\
\hline \multicolumn{8}{|l|}{ Районы: } \\
\hline Ижемский & 26122 & 4593 & 21529 & 17,6 & 82,4 & 3090 & 11,8 \\
\hline Княжпогостский & 37808 & 17340 & 20468 & 45,9 & 54,1 & 13529 & 35,8 \\
\hline Койгородский & 17431 & 1095 & 16336 & 6,3 & 93,7 & 2230 & 12,8 \\
\hline Корткеросский & 31780 & - & 31780 & - & 100 & 2864 & 9 \\
\hline Печорский & 37368 & 12217 & 25151 & 32,7 & 67,3 & - & - \\
\hline Прилузский & 35756 & - & 35756 & - & 100 & 2894 & 8,1 \\
\hline Сыктывдинский & 26305 & 1630 & 24675 & 6,2 & 93,8 & 4787 & 18,2 \\
\hline Сысольский & 22060 & - & 22060 & - & 100 & 4459 & 20,2 \\
\hline Троицко-Печорский & 29388 & 4172 & 25216 & 14,2 & 85,8 & 4538 & 15,4 \\
\hline Удорский & 20078 & - & 20078 & - & 100 & 3141 & 15,6 \\
\hline Усть-Вымский & 41173 & 19057 & 22116 & 46,3 & 53,7 & 3736 & 9,1 \\
\hline
\end{tabular}


Окончание табл. 3

\begin{tabular}{|c|c|c|c|c|c|c|c|}
\hline \multirow{2}{*}{$\begin{array}{c}\text { Низовые } \\
\text { административные }\end{array}$} & \multirow{2}{*}{$\begin{array}{c}\text { Всё } \\
\text { районы }\end{array}$} & \multicolumn{2}{|c|}{$\begin{array}{c}\text { В том числе } \\
\text { нелен, }\end{array}$} & $\begin{array}{c}\text { Доля в общей } \\
\text { численности населения, \% }\end{array}$ & \multicolumn{2}{|c|}{$\begin{array}{c}\text { Людность админи- } \\
\text { стративного центра }\end{array}$} \\
\cline { 3 - 9 } & $\begin{array}{c}\text { Городское } \\
\text { население }\end{array}$ & $\begin{array}{c}\text { Сельское } \\
\text { население }\end{array}$ & $\begin{array}{c}\text { Городское } \\
\text { население }\end{array}$ & $\begin{array}{c}\text { Сельское } \\
\text { население }\end{array}$ & Человек & $\begin{array}{c}\text { В \% ко всему } \\
\text { населению }\end{array}$ \\
\hline Усть-Куломский & 43625 & - & 43625 & - & 100 & 5187 & 11,9 \\
\hline Усть-Цилемский & 18911 & - & 18911 & - & 100 & 5370 & 28,4 \\
\hline
\end{tabular}

Составлено и рассчитано по: Всесоюзная перепись населения 1970 г. Численность наличного населения городов и районов по республикам, краям и областям РСФСР (www.demoscope.ru/weekly/ssp/rus70_reg2/php)

В 13 из 18 низовых административных районов республики преобладало сельское население, а в шести из них сельские жители составляли 100 \% всего населения. Во всех 11 селах, выполняющих роль административных центров районов, в межпереписной период произошло увеличение людности. В совокупности в них проживало 42,3 тыс. чел., что составило 11,5 \% сельского населения республики. По данным переписи населения 1970 г., самыми людными селами - районными центрами были Усть-Цильма (5,4 тыс. чел.), Усть-Кулом (5,2 тыс.), Выльгорт (4,8 тыс.), Троицко-Печорск (4,5 тыс.), Визинга (4,5 тыс.) и Айкино (3,7 тыс. чел.). В остальных селах - районных центрах людность варьировалась в пределах от 2,2 до 3,1 тыс. чел. По уровню концентрации населения в административном центре района выделялись Усть-Цилемский $(28,4$ \%) и Сысольский (20,2 \%) районы. В Сыктывдинском, Троицко-Печорском и Удорском районах доля административного центра в населении района варьировалась от 15 до 20 \%, в Ижемском, Койгородском и Усть-Куломском районах - от 10 до 15 \%, в Корткеросском, Прилузском и Усть-Вымском районах - от 5 до 10 \%.

Ввод в эксплуатацию крупных промышленных и транспортных объектов в городах и рабочих поселках юго-западной и центральной частей республики способствовал повышению доли проживающих в пределах Ближнего Севера до 40,9 \% и Среднего Севера до 32,6 \%. при этом удельный вес районов Дальнего Севера снизился до 26,5 \%. Однако эти изменения в целом не повлияли на характер сложившегося с конца 1950-х гг. распределения населения по территории республики (табл. 4).

Распределение населения Коми АССР по подзонам Севера в 1959-1970 22.

Таблица 4

\begin{tabular}{|c|c|c|c|c|c|c|c|c|}
\hline \multirow{3}{*}{ Годы } & \multirow{2}{*}{\multicolumn{2}{|c|}{ Республика Коми }} & \multicolumn{6}{|c|}{ Подзоны Севера } \\
\hline & & & \multicolumn{2}{|c|}{ Дальний Север } & \multicolumn{2}{|c|}{ Средний Север } & \multicolumn{2}{|c|}{ Ближний Север } \\
\hline & $\begin{array}{c}\text { тыс. } \\
\text { человек }\end{array}$ & $\begin{array}{c}\text { В \% к } \\
\text { Коми АССР }\end{array}$ & $\begin{array}{c}\text { тыс. } \\
\text { человек }\end{array}$ & $\begin{array}{c}\text { В \% к } \\
\text { Коми АССР }\end{array}$ & $\begin{array}{c}\text { тыс. } \\
\text { человек }\end{array}$ & $\begin{array}{c}\text { В \% к } \\
\text { Коми АССР }\end{array}$ & $\begin{array}{c}\text { тыс. } \\
\text { человек }\end{array}$ & $\begin{array}{c}\text { В \% к } \\
\text { Коми АССР }\end{array}$ \\
\hline 1959 & 815,8 & 100 & 251,3 & 30,8 & 236,5 & 29 & 328 & 40,2 \\
\hline 1970 & 964,8 & 100 & 255,7 & 26,5 & 314,5 & 32,6 & 394,6 & 40,9 \\
\hline
\end{tabular}

Составлено и рассчитано по: Всесоюзная перепись населения на 15 января 1959 г. Численность наличного населения городов и районов по республикам, краям и областям РСФСР (www.demoscope.ru/weekly/ssp/rus59_reg1.php); Всесоюзная перепись населения 1970 г. Численность наличного населения городов и районов по республикам, краям и областям РСФСР (www.demoscope.ru/weekly/ssp/rus70_reg2/php).

В 1970-е гг. определяющее влияние на динамику и характер демографических процессов в регионе оказали резко возросшие масштабы добычи и переработки топливно-энергетических ресурсов, наращивание объемов лесозаготовок, деревообработки и лесопереработки. Хозяйственное освоение новых районов добычи углеводородного сырья и разработка лесных ресурсов вызвали преимущественно экстенсивный рост сети городских населенных пунктов и городского населения. В 1974 г. число жителей региона впервые превысило 1 млн. чел. В межпереписной период с 1970 по 1979 г. численность населения Коми АССР увеличилась с 964,4 тыс. до 1118,4 тыс. чел., или на $16 \%$ [7].

В межпереписной период с 1970 по 1979 г. наиболее динамично увеличивался демографический потенциал низовых административных районов, на территории которых в эти годы ускоренно развивались отрасли топливно-энергетического и лесопромышленного комплексов. В 1970-е гг. в 11 низовых административных районах произошло увеличение численности населения, а в 9 - снижение людности. В рассматриваемый период в 1,8 раза увеличилась численность населения Удорского района, где в эти годы началось сотрудничество в заготовке леса для нужд народного хозяйства Народной Республики Болгарии в рамках Соглашения между правительствами СССР и НРБ. В эти годы в 1,4 раза увеличилось население Сыктывкарского и Печорского горсоветов, на 14,7 \% - Ухтинского горсовета, 5,3 \% - Воркутинского горсовета, 2,4 \% - Усть-Вымского района, $1,5 \%$ - Княжпогосткого района, $0,5 \%$ - Интинского горсовета, на 0,3 \% - Сыктывдинского района. Устойчивый рост населения наблюдался также в Вуктыльском и Усинском районах, образованных в 1975 г. Между тем в эти годы на 23,8 \% сократилось население Печорского района, на 14,6 \% - Прилузского, 13,6 \% - Койгородского, 
11,4 \% - Сысольского, 11,3 \% - Корткеросского, 9,6 \% - Усть-Цилемского, 3,4 \% - Усть-Куломского, 3,1 \% Ижемского и на $2,2 \%$ - Троицко-Печорского районов.

По данным переписи населения 1979 г., самым людным низовым административным районом республики оставался Воркутинский горсовет (194,8 тыс. чел.). На второе место по численности населения вышел Сыктывкарский горсовет (187,3 тыс.), на третье - Ухтинский горсовет район (173,6 тыс.), на четветое - Интинский горсовет (61,8 тыс.), на пятое - Печорский горсовет (61,8 тыс. чел.). В этих пяти горсоветах концентрировалось 60,3 \% всего населения республики, из них 17,4 \% составляло население Воркутинского горсовета. Среди остальных 15 низовых административных районов два (Усинский и Усть-Вымский районы) имели людность в пределах от 40,1 до 45 тыс. чел., четыре (Княжпогостский, Прилузский, Удорский и Усть-Куломский районы) - от 30,1 до 40 тыс. чел., шесть (Вуктыльский, Ижемский, Корткеросский, Печорский, Сыктывдинский и Троицко-Печорский районы) - от 20,1 до 30 тыс. чел. и три (Койгородский, Сысольский и Усть-Цилемский районы ) - от 10,1 до 20 тыс. чел.

На дату переписи населения 1979 г. в 16 из 20 низовых административных районов имелись городские населенные пункты и городское население, но в 10 из 20 преобладало сельское население, в том числе в трех сельские жители составляли 100 \% всего населения. Во всех 10 селах, выполняющих роль административных центров районов, в межпереписной период произошло увеличение людности. В совокупности в селах районных центрах проживало 45,8 тыс. чел., что составило 14,1 \% сельского населения республики. Самыми людными селами - районными центрами были Выльгорт (8,5 тыс. чел.), Визинга (5,6 тыс.), Усть-Цильма (5,5 тыс.), Усть-Кулом (5,4 тыс.), Кослан (3,9 тыс.) и Айкино (3,9 тыс. чел.). В остальных селах - районных центрах (Койгородок, Корткерос, Объячево) людность варьировалась в пределах от 3,1 до 3,5 тыс. чел. По уровню концентрации населения в административном центре района выделялись Усть-Цилемский $(32,2 \%)$ Сысольский $(28,5$ \%) и Койгородский $(20,4$ \%) районы. В Ижемском, Корткеросском, Прилузском, Удорском и Усть-Куломском районах доля административного центра в населении района варьировалась от 10 до $15 \%$ и лишь в Усть-Вымском районе - менее 10 \% (табл. 5).

Таблица 5

Численность и структура городского и сельского населения Коми АССР по данным Всесоюзной переписи населения 1979 г.

\begin{tabular}{|c|c|c|c|c|c|c|c|}
\hline \multirow{2}{*}{\begin{tabular}{|c|} 
Низовые \\
административные \\
районы
\end{tabular}} & \multirow{2}{*}{$\begin{array}{c}\text { Всё } \\
\text { население, } \\
\text { чел. }\end{array}$} & \multicolumn{2}{|c|}{ В том числе } & \multicolumn{2}{|c|}{$\begin{array}{c}\text { Доля в общей } \\
\text { численности населения, \% }\end{array}$} & \multicolumn{2}{|c|}{$\begin{array}{c}\text { Людность } \\
\text { административного центра }\end{array}$} \\
\hline & & $\begin{array}{l}\text { Городское } \\
\text { население }\end{array}$ & $\begin{array}{l}\text { Сельское } \\
\text { население }\end{array}$ & $\begin{array}{l}\text { Городское } \\
\text { население }\end{array}$ & $\begin{array}{c}\text { Сельское } \\
\text { население }\end{array}$ & Человек & $\begin{array}{c}\text { В \% ко всему } \\
\text { населению }\end{array}$ \\
\hline Коми АССР, всего & 1118421 & 793441 & 324980 & 70,9 & 29,1 & 170980 & 15,3 \\
\hline \multicolumn{8}{|l|}{ Горсоветы: } \\
\hline Сыктывкарский & 187347 & 185147 & 2200 & 98,8 & 1,2 & 170980 & 91,3 \\
\hline Воркутинский & 194823 & 193047 & 1776 & 99,1 & 0,9 & 100210 & 51,4 \\
\hline Интинский & 61830 & 56814 & 5016 & 91,9 & 8,1 & 50862 & 82,3 \\
\hline Печорский & 56409 & 56361 & 48 & 99,9 & 0,1 & 56361 & 99,9 \\
\hline Ухтинский & 173625 & 154945 & 18680 & 89,2 & 10,8 & 87467 & 50,4 \\
\hline \multicolumn{8}{|l|}{ Районы: } \\
\hline Вуктыльский & 25323 & 16767 & 8556 & 66,2 & 33,8 & 16767 & 66,2 \\
\hline Ижемский & 24305 & 4395 & 19910 & 18,1 & 81,9 & 3253 & 13,4 \\
\hline Княжпогостский & 38370 & 22742 & 15628 & 59,3 & 40,7 & 15936 & 41,5 \\
\hline Койгородский & 15053 & 1466 & 13587 & 9,7 & 90,3 & 3068 & 20,4 \\
\hline Корткеросский & 28176 & - & 28176 & - & 100 & 3353 & 11,9 \\
\hline Печорский & 28474 & 14903 & 13571 & 52,3 & 47,7 & - & - \\
\hline Прилузский & 30526 & - & 30526 & - & 100 & 3458 & 11,3 \\
\hline Сыктывдинский & 26391 & 1228 & 25163 & 4,7 & 95,3 & 8512 & 32,3 \\
\hline Сысольский & 19551 & - & 19551 & - & 100 & 5572 & 28,5 \\
\hline Троицко-Печорский & 28747 & 12591 & 16156 & 43,8 & 56,2 & 9240 & 32,1 \\
\hline Удорский & 35383 & 17294 & 18089 & 48,9 & 51,1 & 3878 & 11 \\
\hline Усинский & 44945 & 31383 & 13562 & 69,8 & 30,2 & 19513 & 43,4 \\
\hline Усть-Вымский & 42157 & 22405 & 19752 & 53,1 & 46,9 & 3855 & 9,1 \\
\hline Усть-Куломский & 39898 & 1953 & 37945 & 4,9 & 95,1 & 5355 & 13,4 \\
\hline Усть-Цилемский & 17088 & - & 17088 & - & 100 & 5498 & 32,2 \\
\hline
\end{tabular}

Составлено и рассчитано по: Всесоюзная перепись населения 1979 г. Численность наличного населения городов и районов по республикам, краям и областям РСФСР (www.demoscope.ru/weekly/ssp/rus79_reg2/php). 
Сдвиг производительных сил в районы добычи топливно-энергетических ресурсов, где в 1970-е гг. были достигнуты исторические максимумы объемов добычи нефти, природного газа и угля, способствовал дальнейшему перераспределению населения в пользу северных территорий республики. В межпереписной период с 1970 по 1979 г. доля Дальнего Севера увеличилась с 26,5 до 27 \%, а Среднего Севера - с 32,6 до 34,8 \%. Повышение удельного веса районов Дальнего и Среднего Севера сопровождалось уменьшением доли Ближнего Севера в населении региона, которая в эти годы снизилась с 40,9 до 38,2 \%.

В период с 1980 по 1990 г. численность населения Коми АССР увеличилась с 1129,4 до 1264,9 тыс. чел., или на 12 \%. В 1990 г. численность населения Республики Коми достигла максимальной величины за всю историю - 1264,9 тыс. чел., после чего началось непрерывное сокращение демографического потенциала [8].

На рубеже 1970-1980-х гг. были достигнуты исторические максимумы людности в Ижемском, Койгородском, Корткеросском, Прилузском и Троицко-Печорском районах. С этого времени в этих районах наблюдается непрерывное снижение численности населения. В остальных 15 районах республики максимальные показатели людности были зафиксированы в конце 1980-х гг. В 1987 г. максимальную людность показали г. Печора и Печорский район (95,2 тыс. чел.), Вуктыльский (28,4 тыс.), Сосногорский (63,3 тыс.) и Удорский (39,8 тыс. чел.) районы, в 1989 г. - Княжпогостский (40,4 тыс.) и Сысольский (19,6 тыс. чел.) районы, в 1990 г. - Сыктывкарский (238 тыс. чел.), Воркутинский (217 тыс.), Интинский (70 тыс.) и Ухтинский (140 тыс. чел.) горсоветы, г. Усинск и Усинский район (71,7 тыс. чел.), а также Сыктывдинский район (27,5 тыс. чел.). Эти изменения нашли отражение в территориальной структуре городского и сельского населения Коми АССР по данным последней Всесоюзной переписи населения 1989 г. (табл. 6).

\section{Численность и структура городского и сельского населения Коми АССР по данным Всесоюзной переписи населения 1989 2.}

\begin{tabular}{|c|c|c|c|c|c|c|c|}
\hline \multirow{2}{*}{$\begin{array}{c}\text { Низовые } \\
\text { административные } \\
\text { районы }\end{array}$} & \multirow{2}{*}{$\begin{array}{c}\text { Всё } \\
\text { население, } \\
\text { чел. }\end{array}$} & \multicolumn{2}{|c|}{ В том числе } & \multicolumn{2}{|c|}{$\begin{array}{c}\text { Доля в общей числен- } \\
\text { ности } \\
\text { населения, \% }\end{array}$} & \multicolumn{2}{|c|}{$\begin{array}{c}\text { Людность } \\
\text { административного центра }\end{array}$} \\
\hline & & $\begin{array}{l}\text { Городское } \\
\text { население }\end{array}$ & $\begin{array}{c}\text { Сельское } \\
\text { население }\end{array}$ & $\begin{array}{l}\text { Городское } \\
\text { население }\end{array}$ & $\begin{array}{c}\text { Сельское } \\
\text { население }\end{array}$ & Человек & $\begin{array}{c}\text { В \% ко всему } \\
\text { населению }\end{array}$ \\
\hline Коми АССР, всего & 1261024 & 952278 & 308746 & 75,5 & 24,5 & 232117 & 18,4 \\
\hline \multicolumn{8}{|l|}{ Горсоветы и города: } \\
\hline Сыктывкарский & 235309 & 234529 & 780 & 99,7 & 0,3 & 232117 & 98,6 \\
\hline Воркутинский & 216176 & 214527 & 1649 & 99,2 & 0,8 & 115646 & 53,5 \\
\hline Интинский & 69898 & 66356 & 3542 & 94,9 & 5,1 & 60220 & 86,2 \\
\hline г. Печора & 64746 & 64746 & - & 100 & - & 64746 & 100 \\
\hline г. Усинск & 47219 & 47219 & - & 100 & - & 47219 & 100 \\
\hline Ухтинский & 140545 & 136931 & 3614 & 97,4 & 2,6 & 110548 & 78,7 \\
\hline \multicolumn{8}{|l|}{ Районы: } \\
\hline Вуктыльский & 28228 & 19330 & 8898 & 68,5 & 31,5 & 19330 & 31,5 \\
\hline Ижемский & 23315 & 4122 & 19193 & 17,7 & 82,3 & 3595 & 15,4 \\
\hline Княжпогостский & 40359 & 25339 & 15020 & 62,8 & 37,2 & 18782 & 46,5 \\
\hline Койгородский & 12541 & 1366 & 11175 & 10,9 & 89,1 & 2923 & 23,3 \\
\hline Корткеросский & 27555 & - & 27555 & - & 100 & 4373 & 15,9 \\
\hline Печорский & 28874 & 16546 & 12328 & 57,3 & 42,7 & - & - \\
\hline Прилузский & 28674 & - & 28674 & - & 100 & 5273 & 100 \\
\hline Сосногорский & 62455 & 50292 & 12163 & 80,5 & 19,5 & 30439 & 48,7 \\
\hline Сыктывдинский & 27396 & 1041 & 26355 & 3,8 & 96,2 & 8965 & 32,7 \\
\hline Сысольский & 19568 & - & 19568 & - & 100 & 7014 & 35,8 \\
\hline Троицко-Печорский & 26198 & 13147 & 13051 & 50,2 & 49,8 & 10704 & 41 \\
\hline Удорский & 39729 & 19227 & 20502 & 48,4 & 51,6 & 3812 & 18,6 \\
\hline Усинский & 22301 & 10132 & 12169 & 45,4 & 54,6 & - & - \\
\hline Усть-Вымский & 43236 & 25181 & 18055 & 58,2 & 41,8 & 3895 & 9 \\
\hline Усть-Куломский & 40145 & 2247 & 37898 & 5,6 & 94,4 & 5888 & 14,7 \\
\hline Усть-Цилемский & 16557 & - & 16557 & - & 100 & 5344 & 32,3 \\
\hline
\end{tabular}

Составлено и рассчитано по: Всесоюзная перепись населения 1989 г. Численность наличного населения городов и районов по республикам, краям и областям РСФСР (www.demoscope.ru/weekly/ssp/rus89_reg2/php). 
В 1989 г. самым людным низовым административным районом республики впервые стал Сыктывкарский горсовет, на территории которого проживало 235,3 тыс. чел., или 18,7 \% всего населения Коми АССР. На второе место опустился Воркутинский горсовет (216,2 тыс. чел.), который несколько послевоенных десятилетий возглавлял рейтинг людности низовых административных районов республики. Третье место занял Ухтинский горсовет (140,5 тыс. чел.), четвертое - Интинский горсовет (69,9 тыс.), пятое - Печорский горсовет (64,7 тыс.) и шестое место - Сосногорский район, выделенный в 1979 г. из состава Ухтинского горсовета. В период с 1979 по 1990 г. в 13 низовых административных районах, связанных с развитием отраслей профилирующих в регионе топливно-энергетического и лесопромышленного комплексов, произошло увеличение людности. При этом в семи районах лесозаготовительно-сельскохозяйственного профиля численность населения сократилась. В 1989 г. в шести самых людных низовых административных районах республики концентрировалось 62,6 \% всего населения республики, из них 18,7 \% приходилось на Сыктывкарский горсовет. Среди остальных 14 низовых административных районов четыре (Усинский горсовет, Княжпогостский, Усть-Вымский и Усть-Куломский районы) имели людность в пределах от 40,1 до 50 тыс. чел., один (Удорский район) - от 39,1 до 40 тыс. чел., восемь (Вуктыльский, Ижемский, Корткеросский, Печорский, Прилузский, Сыктывдинский, Троицко-Печорский и Усинский районы) - от 20,1 до 30 тыс. чел. и три (Койгородский, Сысольский и Усть-Цилемский районы ) от 10,1 до 20 тыс. чел. (табл. 7).

Динамика численности населения низовых административных районов

Таблица 7

Коми АССР в 1979-1990 г2., тыс. чел.

\begin{tabular}{|l|c|c|c|c|c|}
\hline $\begin{array}{c}\text { Низовые } \\
\text { административные районы }\end{array}$ & 1979 г. & 1985 г. & 1987 г. & 1989 г. & 1990 г. \\
\hline Коми АССР, всего & $\mathbf{1 1 1 8 , 4}$ & $\mathbf{1 2 0 5 , 5}$ & $\mathbf{1 2 4 7}$ & $\mathbf{1 2 6 1}$ & $\mathbf{1 2 6 4 , 9}$ \\
\hline Горсовет: & \multicolumn{5}{|l|}{} \\
\hline Сыктывкарский & 187,3 & 216,9 & 228,5 & 235,3 & 238 \\
\hline Воркутинский & 194,8 & 206,3 & 215 & 216,2 & 217 \\
\hline Интинский & 61,8 & 66,2 & 68,3 & 69,9 & 70 \\
\hline Ухтинский & 113,5 & 130 & 135,9 & 140,5 & 140,9 \\
\hline г. Печора и Печорский район & 84,9 & 92,9 & 95,2 & 93,6 & 93,9 \\
\hline г. Усинск и Усинский район & 44,9 & 63,2 & 67,9 & 69,5 & 71,7 \\
\hline Районы: & \multicolumn{5}{|l|}{} \\
\hline Вуктыльский & 25,3 & 27,7 & 28,4 & 28,2 & 27,5 \\
\hline Ижемский & 24,3 & 22,5 & 22,6 & 23,3 & 23,4 \\
\hline Княжпогостский & 38,4 & 38,4 & 39,1 & 40,4 & 40,1 \\
\hline Койгородский & 15,1 & 13,8 & 13,6 & 12,5 & 12,2 \\
\hline Корткеросский & 28,2 & 27,7 & 28 & 27,6 & 27,3 \\
\hline Прилузский & 30,5 & 29,2 & 28,8 & 28,7 & 28,8 \\
\hline Сосногорский & 60,1 & 60,7 & 63,3 & 62,5 & 62,4 \\
\hline Сыктывдинский & 26,4 & 26,3 & 27,2 & 27,4 & 27,5 \\
\hline Сысольский & 19,6 & 19,3 & 19,2 & 19,6 & 19,3 \\
\hline Троицко-Печорский & 28,7 & 27,9 & 27,8 & 26,2 & 26,1 \\
\hline Удорский & 35,4 & 38,3 & 39,8 & 39,7 & 39,3 \\
\hline Усть-Вымский & 42,2 & 43,1 & 43,3 & 43,2 & 42,9 \\
\hline Усть-Куломский & 39,9 & 38,7 & 38,6 & 40,1 & 39,9 \\
\hline Усть-Цилемский & 17,1 & 16,4 & 16,5 & 16,6 & 16,7 \\
\hline
\end{tabular}

Составлено и рассчитано по данным Всесоюзных переписей населения и текущего учета населения Комистата.

В 1980-е гг. самый значительный рост демографического потенциала продемонстрировали г. Усинск с Усинским районом и Сыктывкарский горсовет, население которых выросло соответственно в 1,6 и 1,3 раза. Совокупная численность Ухтинского горсовета и Сосногорского района, которые на дату проведения переписи 1979 г. представляли собой единый низовой административный район (Ухтинский горсовет), выросла на 24,1%. В рассматриваемый период на 13,3 \% увеличилась людность Интинского горсовета, на 11,4 \% - Воркутинского горсовета, $11 \%$ - Удорского района, 10,6 \% - г. Печоры и Печорского района, 8,7 \% - Вуктыльского района, 4,4 \% - Княжпогостского района, 4,2 \% - Сыктывдинского района и на 1,7 \% - Усть-Вымского района. При этом людность Усть-Куломского района в 1979 и 1990 гг. была на одинаковом уровне (39,9 тыс. чел.). Между тем с 1979 по 1990 г. на 19,2 \% сократилось население Койгородского района, на 9,1% - Троицко-Печорского, 
5,6 \% - Прилузского, 3,7 \% - Ижемского, 2,3 \% - Усть-Цилемского, 3,2 \% - Корткеросского и на 1,5 \% - Сысольского районов.

По характеру изменения удельного веса низовых административных районов в численности населения республики в 1980-е гг. их можно разделить на четыре группы. Самую многочисленную группу образуют низовые административные районы (г. Печора и Печорский район, Вуктыльский, Ижемский, Княжпогостский, Койгородский, Корткеросский, Прилузский, Сыктывдинский, Троицко-Печорский, Удорский, Усть-Вымский, УстьКуломский и Усть-Цилемский), в которых удельный вес в населении республики уменьшился по сравнению с 1979 г. и в конце 1980-х гг. стабилизировался на низком уровне. Вторая группа охватывает низовые административные районы (Сосногорский и Сысольский районы) с непрерывным снижением удельного веса в течение 1980-х гг. В третью - входят низовые административные районы (Сыктывкарский и Ухтинский горсоветы, г. Усинск и Усинский район), в которых в 1980-е гг. произошло увеличение удельного веса в населении республики. При этом в единственном низовом административном районе (Интинский горсовет) это показатель был неизменным в течение всего рассматриваемого периода (табл. 8).

Таблица 8

Изменение удельного веса низовых административных районов в численности наличного населения Республики Коми в 1979-1990 гг., \%

\begin{tabular}{|l|c|c|c|c|c|}
\hline \multicolumn{1}{c|}{$\begin{array}{c}\text { Низовые } \\
\text { административные районы }\end{array}$} & 1979 г. & 1985 г. & 1987 г. & 1989 г. & 1990 г. \\
\hline Коми АССР, всего & $\mathbf{1 0 0}$ & $\mathbf{1 0 0}$ & $\mathbf{1 0 0}$ & $\mathbf{1 0 0}$ & $\mathbf{1 0 0}$ \\
\hline Сыктывкарский горсовет & 16,7 & 18 & 18,3 & 18,7 & 18,8 \\
\hline Воркутинский горсовет & 17,4 & 17,1 & 17,2 & 17,1 & 17,2 \\
\hline Интинский горсовет & 5,5 & 5,5 & 5,5 & 5,5 & 5,5 \\
\hline Ухтинский горсовет & 10,1 & 10,8 & 10,9 & 11,1 & 11,1 \\
\hline г. Печора и Печорский район & 7,6 & 7,7 & 7,6 & 7,4 & 7,4 \\
\hline г. Усинск и Усинский район & 4 & 5,2 & 5,4 & 5,5 & 5,7 \\
\hline Вуктыльский район & 2,3 & 2,3 & 2,3 & 2,2 & 2,2 \\
\hline Ижемский район & 2,2 & 1,9 & 1,8 & 1,8 & 1,8 \\
\hline Княжпогостский район & 3,4 & 3,2 & 3,1 & 3,2 & 3,2 \\
\hline Койгородский район & 1,3 & 1,1 & 1,1 & 1 & 1 \\
\hline Корткеросский район & 2,5 & 2,3 & 2,2 & 2,2 & 2,2 \\
\hline Прилузский район & 2,7 & 2,4 & 2,3 & 2,3 & 2,3 \\
\hline Сосногорский район & 5,4 & 5 & 5,1 & 5 & 4,9 \\
\hline Сыктывдинский район & 2,4 & 2,2 & 2,2 & 2,2 & 2,2 \\
\hline Сысольский район & 1,8 & 1,6 & 1,5 & 1,6 & 1,5 \\
\hline Троицко-Печорский район & 2,6 & 2,3 & 2,2 & 2,1 & 2,1 \\
\hline Удорский район & 3,2 & 3,2 & 3,2 & 3,1 & 3,1 \\
\hline Усть-Вымский район & 3,8 & 3,6 & 3,5 & 3,4 & 3,4 \\
\hline Усть-Куломский район & 3,6 & 3,2 & 3,1 & 3,2 & 3,2 \\
\hline Усть-Цилемский район & 1,5 & 1,4 & 1,3 & 1,3 & 1,3 \\
\hline
\end{tabular}

Составлено и рассчитано по данным Всеоюзных переписей и текущего учёта населения Комистата.

Одновременно с достижением максимальной численности населения Коми АССР в 1990 г. был показан исторический максимум средней плотности населения. В период с 1979 по 1990 г. средняя плотность населения Коми АССР увеличилась с 2,7 до трех человек на 1 кв. км. Во многом схожие тенденции изменения средней плотности населения наблюдались в разрезе низовых административных районов республики. К концу рассматриваемого периода в 11 из 20 низовых административных районов с преобладанием городского населения (Сыктывкарский, Воркутинский, Интинский и Ухтинский горсоветы, г. Печора и Печорский район, г. Усинск и Усинский район, Вуктыльский, Сосногорский, Удорский и Усть-Вымский районы) произошло увеличение средней плотности населения, в трех (Койгородский, Прилузский и Троицко-Печорский районы) - снижение и в шести (Ижемский, Княжпогостский, Корткеросский, Сысольский, Усть-Куломский и Усть-Цилемский районы) - она не изменилась.

Самый значительный рост средней плотности с 1979 по 1990 г. произошел в г. Усинске и Усинском районе (в 1,5 раза), Сыктывкарском (на 25,6 \%) и Ухтинском (на 23,3 \%) горсоветах и Вуктыльском районе (в 1,2 раза), а самое значительное снижение - в Койгородском районе (на $25 \%$ ). По территориальной концентрации населения среди низовых районов республики резко выделяются Сыктывкарский, Ухтинский, Воркутинский горсоветы и Усть-Вымский район, в которых средняя плотность населения в 1990 г. была выше 
среднереспубликанской в три и более раза. В четырех низовых административных районах (г. Печора и Печорский район, Сосногорский, Сыктывдинский и Сысольский районы) средняя плотность населения варьировалась в пределах от трех до четырех человек на 1 кв. км, в трех (Интинский горсовет, г. Усинск и Усинский район, Прилузский район) - от двух до трех человек на 1 кв. км, в семи (Вуктыльский, Ижемский, Княжпогостский, Койгородский, Корткеросский, Удорский и Усть-Куломский районы) - от одного до двух человек на 1 кв. км и в двух (Троицко-Печорский и Усть-Цилемский районы) была менее одного человека на 1 кв. км.

В период с 1979 по 1990 г. плотность сельского населения республики снизилась с 0,8 до 0,7 чел. на 1 кв. км. В 1990 г. в девяти из 20 низовых административных районов республики преобладало сельское население, а в четырех из них сельские жители составляли 100 \% всего населения. В рассматриваемый период снижение плотности сельского населения произошло в десяти (Сыктывкарский, Интинский, Ухтинский горсовет, г. Печора и Печорский район, Ижемский, Койгородский, Прилузский, Сосногорский, Троицко-Печорский и Усть-Вымский районы) из 20 низовых районов республики (табл. 9).

Таблица 9

Изменение средней плотности всего населения и плотности сельского населения Республики Коми в 1979-1990 гг., \%

\begin{tabular}{|c|c|c|c|c|c|c|}
\hline \multirow{2}{*}{$\begin{array}{c}\text { Низовые } \\
\text { административные районы }\end{array}$} & \multicolumn{3}{|c|}{$\begin{array}{c}\text { Средняя плотность всего населения, } \\
\text { чел. на } 1 \text { кв. км } \\
\end{array}$} & \multicolumn{3}{|c|}{$\begin{array}{c}\text { Плотность сельского населения, } \\
\text { чел. на } 1 \text { кв. км } \\
\end{array}$} \\
\hline & 1979 г. & 1989 г. & 1990 г. & 1979 г. & 1989 г. & 1990 г \\
\hline Коми АССР, всего & 2,7 & 3 & 3 & 0,8 & 0,7 & 0,7 \\
\hline Сыктывкарский горсовет & 267,6 & 336,1 & 340 & 3 & 1,1 & 1,1 \\
\hline Воркутинский горсовет & 8 & 8,9 & 9 & 0,1 & 0,1 & 0,1 \\
\hline Интинский горсовет & 2,1 & 2,3 & 2,3 & 0,2 & 0,1 & 0,1 \\
\hline Ухтинский горсовет & 8,6 & 10,6 & 10,7 & 0,3 & 0,3 & 0,2 \\
\hline г. Печора и район & 2,9 & 3,2 & 3,2 & 0,5 & 0,4 & 0,4 \\
\hline г. Усинск и район & 1,5 & 2,3 & 2,3 & 0,4 & 0,4 & 0,4 \\
\hline Вуктыльский район & 1,1 & 1,3 & 1,2 & 0,4 & 0,4 & 0,4 \\
\hline Ижемский район & 1,3 & 1,3 & 1,3 & 1,1 & 1 & 1 \\
\hline Княжпогостский район & 1,6 & 1,6 & 1,6 & 0,6 & 0,6 & 0,6 \\
\hline Койгородский район & 1,5 & 1,2 & 1,2 & 1,3 & 1,1 & 1 \\
\hline Корткеросский район & 1,4 & 1,4 & 1,4 & 1,4 & 1,4 & 1,4 \\
\hline Прилузский район & 2,3 & 2,2 & 2,2 & 2,3 & 2,2 & 2,2 \\
\hline Сосногорский район & 3,6 & 3,8 & 3,8 & 0,9 & 0,7 & 0,7 \\
\hline Сыктывдинский район & 3,6 & 3,7 & 3,7 & 3,4 & 3,6 & 3,6 \\
\hline Сысольский район & 3,2 & 3,2 & 3,2 & 3,2 & 3,2 & 3,2 \\
\hline Троицко-Печорский район & 0,7 & 0,6 & 0,6 & 0,4 & 0,3 & 0,3 \\
\hline Удорский район & 1 & 1,1 & 1,1 & 0,5 & 0,6 & 0,6 \\
\hline Усть-Вымский район & 8,8 & 9 & 8,9 & 4,1 & 3,8 & 3,7 \\
\hline Усть-Куломский район & 1,5 & 1,5 & 1,5 & 1,4 & 1,4 & 1,4 \\
\hline Усть-Цилемский район & 0,4 & 0,4 & 0,4 & 0,4 & 0,4 & 0,4 \\
\hline
\end{tabular}

Составлено и рассчитано по данным Всесоюзных переписей и текущего учёта населения.

В 1990 г. в восьми низовых административных районах (Воркутинский горсовет, город Усинск и Усинский район, Вуктыльский, Княжпогостский, Корткеросский, Сысольский, Усть-Куломский и Усть-Цилемский районы) плотность сельского населения стабилизировалась на одном уровне и лишь в двух (Сыктывдинский и Удорский районы) произошло ее увеличение. В трех низовых административных районах (Сыктывдинский, Сысольский и Усть-Вымский районы) плотность сельского населения варьировалась в пределах от трех до четырех человек на 1 кв. км, в одном (Прилузский район) - от двух до 2,5 чел. на 1 кв. км, в трех (Сыктывкарский горсовет, Корткеросский и Усть-Куломский районы) - от одного до 1,5 чел. на 1 кв. км, в пяти (Ижемский, Княжпогостский, Койгородский, Сосногорский и Удорский районы) - от 0,5 до одного человека на 1 кв. км, в четырех (г. Печора и Печорский район, г. Усинск и Усинский район, Вуктыльский и Усть-Цилемский район) - от 0,3 до 0,5 чел. на 1 кв. км и в четырех (Воркутинский, Интинский, Ухтинский горсоветы и ТроицкоПечорский район) - менее 0,3 чел. на 1 кв. км.

По данным переписи населения 1989 г., в 10 из 20 низовых административных районов республики преобладало сельское население, а в четырех из них сельские жители составляли 100 \% всего населения. Во всех 10 селах, выполняющих роль административных центров районов, в межпереписной период произошло увеличение людности. В совокупности в селах - районных центрах проживало 51,1 тыс. чел., что составило 16,5 \% 
сельского населения республики. Самыми людными селами - районными центрами были Выльгорт (9 тыс. чел.), Визинга (7 тыс.), Усть-Кулом (5,9 тыс.), Усть-Цильма (5,3 тыс.), Объячево (5,3 тыс.), Корткерос (4,4 тыс.), Айкино (3,9 тыс.), Кослан (3,8 тыс.) и Ижма (3,6 тыс. чел.). И только в одном селе - районном центре (Койгородок) людность была менее 3 тыс. чел. По уровню концентрации населения в административном центре района выделялись Сысольский (35,8 \%), Сыктывдинский $(32,7$ \%), Усть-Цилемский (32,3 \%) и Койгородский $(23,3$ \%) районы. В Ижемском, Корткеросском районах доля административного центра в населении района варьировалась от 15 до $20 \%$, в Усть-Куломском район - от 10 до 15 \% и в Усть-Вымском районе - менее $10 \%$.

В 1980-е гг. наблюдался непрерывный рост численности и удельного веса проживающих в районах Дальнего, Среднего и Ближнего Севера. Однако в 1990 г. наметилось снижение численности и удельного веса Среднего Севера. В 1980-е гг. продолжились тенденции перераспределения населения, обозначившиеся в послевоенный период. С 1979 по 1990 г. численность Дальнего Севера в населении республики увеличилась в 1,2 раза, а Среднего и Ближнего Севера - в 1,1 раза. При этом удельный вес Дальнего Севера повысился с 27 до 28,4 \%, а Среднего и Ближнего Севера понизился соответственно с 34,8 до 33,9 \% и с 38,2 до $37,7 \%$ (табл. 10$)$.

Таблица 10

Распределение населения Коми АССР по подзонам Севера в 1979-1990 z2.

\begin{tabular}{|c|c|c|c|c|c|c|c|c|}
\hline \multirow{3}{*}{ Годы } & \multirow{2}{*}{\multicolumn{2}{|c|}{ Коми АССР }} & \multicolumn{6}{|c|}{ Подзоны Севера } \\
\hline & & & \multicolumn{2}{|c|}{ Дальний Север } & \multicolumn{2}{|c|}{ Средний Север } & \multicolumn{2}{|c|}{ Ближний Север } \\
\hline & $\begin{array}{c}\text { Население, } \\
\text { тыс. чел. }\end{array}$ & $\begin{array}{c}\text { В \% к } \\
\text { Коми АССР }\end{array}$ & $\begin{array}{c}\text { Население, } \\
\text { тыс. чел. }\end{array}$ & $\begin{array}{c}\text { В \% к } \\
\text { Коми АССР }\end{array}$ & $\begin{array}{c}\text { Население, } \\
\text { тыс. чел. }\end{array}$ & $\begin{array}{c}\text { В \% к } \\
\text { Коми АССР }\end{array}$ & $\begin{array}{l}\text { Население, } \\
\text { тыс. чел. }\end{array}$ & $\begin{array}{c}\text { В \% к } \\
\text { Коми АССР }\end{array}$ \\
\hline 1979 & 1118,4 & 100 & 302 & 27 & 389,2 & 34,8 & 427,2 & 38,2 \\
\hline 1985 & 1205,6 & 100 & 335,1 & 27,8 & 417,1 & 34,6 & 453,3 & 37,6 \\
\hline 1987 & 1247 & 100 & 351,2 & 28,2 & 429,5 & 34,4 & 466,3 & 37,4 \\
\hline 1989 & 1261 & 100 & 355,6 & 28,2 & 430,7 & 34,2 & 474,7 & 37,6 \\
\hline 1990 & 1264,9 & 100 & 359,2 & 28,4 & 428,8 & 33,9 & 476,9 & 37,7 \\
\hline
\end{tabular}

Составлено и рассчитано по данным Всесоюзных переписей и текущего учета населения.

В начале 1990-х гг. были показаны максимальные показатели численности городского и сельского населения за всё время существования Коми автономии. В 1991 г. был зафиксирован абсолютный исторический максимум численности городского населения (961 тыс. чел.), а в 1993 г. - сельского населения (312 тыс. чел.). В начале 1991 г. был зафиксирован также локальный максимум численности всего населения (1264,7 тыс. чел.) Республики Коми не только в 1990-е гг., но и в постсоветский период.

Весь постсоветский период проходит под знаком непрерывного сокращения демографического потенциала Республики Коми вследствие усиления негативных процессов депопуляции и миграционного оттока населения. С 1991 по 2021 г. численность всего населения Республики Коми уменьшилась с 1264,7 до 813,6 тыс. чел. В абсолютном выражении снижение численности всего населения республики составило 451,1 тыс. чел., а в относительном выражении - на 35,7 \%. Уменьшение численности населения Республики Коми в эти годы на 71,8 \% произошло из-за сокращения численности городского населения. Столь значительное уменьшение численности городского населения было связано с беспрецедентным за всю историю республики свертыванием сети поселков городского типа главным образом за счет их массового перевода в разряд сельских населенных пунктов. При этом в 1990-е гг. впервые за последние полвека в регионе не появился ни один новый городской населенный пункт. В 1991 г. в республике было 16 низовых административных районов, имевших в своем составе городские населенные пункты. Однако в результате преобразования поселков городского типа в сельские населенные пункты число низовых районов с городским населением сократилось до 12, а число низовых административных районов с только сельским населением удвоилось с четырех до восьми. По этой причине с 1992 г. городское население полностью отсутствует в Койгородском и Усть-Куломском районах, а с 1996 г. - в Ижемском и Сыктывдинском районах. При этом городских населенных пунктов и городского населения никогда не было в Корткеросском, Прилузском, Сысольском и Усть-Цилемском районах (табл. 11).

Таблица 11

Изменение численности и структуры городского и сельского населения

Республики Коми в 1991-2021 г2. (по данным текущего учета населения на начало года)

\begin{tabular}{|c|c|c|c|c|c|}
\hline \multirow{2}{*}{ Годы } & \multirow{2}{*}{$\begin{array}{c}\text { Всё население, } \\
\text { тыс. чел. }\end{array}$} & \multicolumn{2}{|c|}{ В том числе } & \multicolumn{2}{c|}{ Доля в общей численности населения, \% } \\
\cline { 3 - 6 } & Городское население & Сельское население & Городское население & Сельское население \\
\hline 1991 & 1264,7 & 961,0 & 303,7 & 76,0 & 24,0 \\
\hline 1993 & 1245,7 & 933,7 & 312,0 & 75,0 & 25,0 \\
\hline 1995 & 1201,6 & 899,6 & 302 & 74,9 & 25,1 \\
\hline
\end{tabular}


Окончание табл. 11

\begin{tabular}{|c|c|c|c|c|c|}
\hline \multirow{2}{*}{ Годы } & \multirow{2}{*}{$\begin{array}{c}\text { Всё население, } \\
\text { тыс. чел. }\end{array}$} & \multicolumn{2}{|c|}{ В том числе } & \multicolumn{2}{|c|}{ Доля в общей численности населения, \% } \\
\cline { 3 - 6 } & 1185,5 & Городское население & Сельское население & Городское население & Сельское население \\
\hline 1996 & 1160,7 & 882,3 & 303,2 & 74,4 & 25,6 \\
\hline 1998 & 1149,2 & 862,0 & 298,7 & 74,3 & 25,7 \\
\hline 1999 & 1134,5 & 841,7 & 292,8 & 74,3 & 25,7 \\
\hline 2000 & 1018,7 & 766,6 & 292,8 & 74,2 & 25,8 \\
\hline 2002 & 901,2 & 691,9 & 252,1 & 75,3 & 24,7 \\
\hline 2010 & 820,5 & 641,7 & 209,3 & 76,8 & 21,8 \\
\hline 2020 & 813,6 & 637,1 & 178,8 & 78,2 & 21,7 \\
\hline 2021 & & 176,5 & 78,3 & \\
\hline
\end{tabular}

Источники: Республика Коми в цифрах. 1991-2021. Сыктывкар: Комистат, 1992-2021.

Примечание. Данные текущего учета приведены на 1 января соответствующего года. В 2002 и 2010 гг. - данные Всероссийских переписей населения.

В 1991-2021 гг. в 19 из 20 низовых административных районах республики уменьшился демографический потенциал после достижения максимальной людности. Единственным низовым административным районом с растущим населением остается город республиканского значения Сыктывкар с подчиненной ему территорией. Между тем в большинстве низовых административных районов убыль населения началась еще в советский период. С начала 1960-х гг. и поныне сокращается население Койгородского района, с начала 1970-х гг. Ижемского, Корткеросского, Прилузского, Сысольского, Усть-Куломского и Усть-Цилемского районов, с 1987 г. -Троицко-Печорского района, с 1988 г. - городов республиканского значения Вуктыла и Сосногорска с подчиненными им территориями, с 1989 г. - Удорского и Усть-Вымского районов, с 1990 г. - Княжпогостского района, с 1991 г. - городов республиканского значения Воркута и Печора с подчиненными им территориями. С 1992 г. наблюдается непрерывная убыль населения в городе республиканского значения Инта с подчиненными ему территориями, с 1993 г. - в городах республиканского значения Усинске и Ухте с подчиненными им территориями, с 1994 г. - в Сыктывдинском районе. Дольше всех продержался город республиканского значения Сыктывкар с подчиненной ему территорией, в котором население начало сокращаться с 2000 г. после достижения локального максимума людности в ХХ в. в 1999 г. (247,8 тыс. чел.), но в последующие годы демонстрировал устойчивый рост численности населения. В 1991 г. максимумы людности в 1990-е гг. были зафиксированы в 13 низовых административных районах республики, в 1993 г. - в трех, в 1994 г. - в двух, в 1995 г. и 1999 г. - в одном. После их достижения происходило непрерывное падение численности населения низового административного района.

В период с 1991 по 2021 г. наибольшие демографические потери понесли города республиканского значения Воркута (-65,7 \%), Инта (-62,5 \%), Вуктыл (-58,6 \%), Печора (-48,8 \%), Усинск (-40,7 \%), Сосногорск $(-32,6 \%)$ с подчиненными им территориями и Троицко-Печорский $(-60,1 \%)$, Удорский $(-55,4$ \%), Княжпогостский $(-52,6 \%)$, Прилузский $(-43,6$ \%), Усть-Вымский $(-41,8 \%)$, Усть-Куломский $(-41,4 \%)$ и Койгородский (-41 \%), Сысольский (-37,1 \%), Усть-Цилемский (-35,7 \%), Корткеросский (-34,3\%) районы, демографический потенциал которых сократился в 1,5-3 раза. В рассматриваемый период на $29 \%$ уменьшилось население Ижемского района, на 20,9 \% - города республиканского значения Ухта и на 10,9 \% - Сыктывдинского района, который в 1990-е гг. стабилизировал свою людность на уровне 27,5-28 тыс. чел. За последние 30 лет только город республиканского значения Сыктывкар с подчиненной ему территорией показывал положительную демографическую динамику, увеличив свой демографический потенциал всего на 7,9 \%, или в среднем на 0,3 \% в год (табл. 12).

Динамика численности населения низовых административных районов Республики Коми

Таблища 12 в 1991-2021 22., тыс. чел.

\begin{tabular}{|c|c|c|c|c|c|c|c|c|c|c|}
\hline Города и районы & 1991 г. & 1993 г. & 1995 г. & 1996 г. & 1998 г. & 1999 г. & 2000 г. & 2002 г. & 2010 г. & 2021 г. \\
\hline Республика Коми, всего & 1264,7 & 1245,7 & 1201,6 & 1185,5 & 1160,7 & 1149,2 & 1134,6 & 1018,8 & 901,2 & 813,6 \\
\hline \multicolumn{11}{|c|}{ Города республиканского значения с подчиненными им территориями: } \\
\hline Сыктывкар & 240,3 & 242,6 & 245,3 & 246,2 & 247,6 & 247,8 & 246,6 & 245,8 & 250,9 & 259,3 \\
\hline Воркута & 216,8 & 209,7 & 192,6 & 184 & 175,8 & 172,2 & 168,9 & 134,2 & 95,9 & 74,4 \\
\hline Вуктыл & 27,3 & 26,3 & 25,8 & 25,9 & 25,7 & 25,3 & 24,8 & 18,3 & 14,9 & 11,3 \\
\hline Инта & 70,2 & 68,4 & 65,3 & 64,1 & 61,8 & 60,8 & 59,4 & 46,4 & 35,2 & 26,3 \\
\hline Печора & 93,5 & 92,4 & 90,6 & 89,4 & 86,9 & 85,6 & 83,5 & 66,3 & 57,4 & 47,9 \\
\hline
\end{tabular}


Окончание табл. 12

\begin{tabular}{|l|c|c|c|c|c|c|c|c|c|c|}
\hline \multicolumn{1}{|c|}{ Города и районы } & 1991 г. & 1993 г. & 1995 г. & 1996 г. & 1998 г. & 1999 г. & 2000 г. & 2002 г. & 2010 г. & 2021 г. \\
\hline Сосногорск & 62,6 & 62,1 & 60,9 & 60,4 & 59,4 & 58,9 & 58,3 & 52,5 & 46,8 & 42,2 \\
\hline Усинск & 72,2 & 71,7 & 66,1 & 63,9 & 61,8 & 61,2 & 59,7 & 52,8 & 47,2 & 42,8 \\
\hline Ухта & 141,9 & 140,8 & 135,7 & 133,1 & 129,6 & 127,9 & 125,6 & 127,4 & 121,7 & 112,3 \\
\hline
\end{tabular}

Районы:

\begin{tabular}{|l|c|c|c|c|c|c|c|c|c|c|}
\hline Ижемский & 23,8 & 24,3 & 24,2 & 24 & 23,5 & 23,4 & 23,3 & 21,5 & 18,8 & 16,9 \\
\hline Княжпогостский & 39 & 36,7 & 34,9 & 34,5 & 33,1 & 32,5 & 31,9 & 29,7 & 23,4 & 18,5 \\
\hline Койгородский & 12,2 & 12,2 & 11,8 & 11,5 & 10,6 & 10,6 & 10,3 & 10 & 8,4 & 7,2 \\
\hline Корткеросский & 27,1 & 27,7 & 26,6 & 26,4 & 26 & 25,9 & 25,9 & 23,6 & 19,7 & 17,8 \\
\hline Прилузский & 29,1 & 29,4 & 28,9 & 28,5 & 28,4 & 28,3 & 28,1 & 24,8 & 20,7 & 16,4 \\
\hline Сыктывдинский & 27,5 & 28,2 & 27,9 & 27,7 & 27,5 & 27,5 & 27,6 & 24,2 & 22,7 & 24,5 \\
\hline Сысольский & 19,4 & 19,3 & 19 & 18,9 & 18,5 & 18,5 & 18,6 & 16,9 & 14 & 12,2 \\
\hline Троицко-Печорский & 25,8 & 25,3 & 23,4 & 22,6 & 21,2 & 20,6 & 20,1 & 17,6 & 13,9 & 10,3 \\
\hline Удорский & 37,2 & 31,8 & 27,3 & 30 & 30,4 & 29,9 & 29,8 & 25,1 & 20,4 & 16,6 \\
\hline Усть-Вымский & 42,1 & 40,6 & 40 & 39,6 & 38,9 & 38,7 & 38,6 & 34 & 29,5 & 24,5 \\
\hline Усть-Куломский & 39,6 & 39,7 & 37,9 & 37,4 & 37 & 36,7 & 36,7 & 32,1 & 26,9 & 23,2 \\
\hline Усть-Цилемский & 17,1 & 17,3 & 17,4 & 17,4 & 17 & 16,9 & 16,9 & 15,4 & 13 & 11 \\
\hline
\end{tabular}

Источники: Республика Коми в цифрах. 1991-2021. Сыктывкар: Комистат, 1992-2021.

Примечание. Данные текущего учета приведены на 1 января соответствующего года. В 2002 и 2010 гг. - данные Всероссийских переписей населения.

По характеру изменения удельного веса низовых административных районов в численности населения республики в постсоветский период их можно разделить на четыре группы. Самая многочисленная группа охватывает 10 низовых административных районов (города республиканского значения Воркута, Вуктыл, Инта, Печора и Усинск с подчиненными им территориями, Княжпогостский, Троицко-Печорский, Удорский, Усть-Вымский и Усть-Куломский районы), в которых произошло уменьшение удельного веса в населении республики. Во вторую группу входят четыре низовых административных района (Койгородский, Корткеросский, Сысольский и УстьЦилемский районы) с практически не изменившимся удельным весом в течение большей части рассматриваемого периода. Третья группа включает три низовых административных района с незначительным увеличением удельного веса (города республиканского значения Сосногорск и Ухта с подчиненными им территориями, Ижемский район) и четвертая группа - два низовых административных района (город республиканского значения Сыктывкар с подчиненной ему территорией и Сыктывдинский район) со значительным (в 1,4-1,7 раза) повышением удельного веса в общей численности населения Республики Коми. При этом за последние 30 лет доля проживающих в городах республиканского значения с подчиненными им территориями увеличилась с 73,1 до 75,8 \%, в то время как доля проживающих в районах уменьшилась с 26,9 до 24,2 \% (табл. 13).

Устойчивое сокращение численности населения республики в 1991-2021 гг. сопровождалось снижением средней плотности населения в 1,5 раза (с 3 до 2 чел. на 1 кв. км) и плотности сельского населения в 1,8 раза (с 0,7 до 0,4 чел. на 1 кв. км). При этом разрыв между средней плотностью всего населения и ее сельского населения за последние 30 лет увеличился с 4,3 раза до 5 раз. Между тем плотность сельского населения определяется в основном мерой участия сельского и лесного хозяйства, а также лесозаготовительной отрасли в структуре занятости населения.

Таблица 13

Изменение удельного веса низовых административных районов в численности наличного населения Республики Коми в 1991-2021 22., \%

\begin{tabular}{|c|c|c|c|c|c|c|c|c|c|c|}
\hline Города и районы & $1991 г$. & 1993 г. & 1995 г. & 1996 г. & 1998 г. & 1999 г. & 2000 г. & 2002 г. & 2010 г. & $2021 г$. \\
\hline Республика Коми, всего & 100 & 100 & 100 & 100 & 100 & 100 & 100 & 100 & 100 & 100 \\
\hline \multicolumn{11}{|c|}{ Города республиканского значения с подчиненными им территориями: } \\
\hline Сыктывкар & 19 & 19,5 & 20,4 & 20,8 & 21,4 & 21,7 & 21,7 & 24,1 & 27,8 & 31,9 \\
\hline Воркута & 17,1 & 16,8 & 16 & 15,5 & 15,1 & 15 & 14,9 & 13,2 & 10,6 & 9,1 \\
\hline Вуктыл & 2,2 & 2,1 & 2,2 & 2,2 & 2,2 & 2,2 & 2,2 & 1,8 & 1,7 & 1,4 \\
\hline Инта & 5,6 & 5,5 & 5,4 & 5,4 & 5,3 & 5,3 & 5,3 & 4,6 & 3,9 & 3,2 \\
\hline Печора & 7,4 & 7,4 & 7,5 & 7,5 & 7,5 & 7,4 & 7,4 & 6,5 & 6,4 & 5,9 \\
\hline Сосногорск & 4,9 & 5 & 5,1 & 5,1 & 5,1 & 5,1 & 5,1 & 5,2 & 5,2 & 5,2 \\
\hline Усинск & 5,7 & 5,8 & 5,5 & 5,4 & 5,3 & 5,3 & 5,3 & 5,2 & 5,2 & 5,3 \\
\hline Ухта & 11,2 & 11,3 & 11,3 & 11,2 & 11,2 & 11,1 & 11,1 & 12,5 & 13,5 & 13,8 \\
\hline
\end{tabular}


Окончание табл. 13

\begin{tabular}{|c|c|c|c|c|c|c|c|c|c|c|}
\hline Города и районы & $1991 г$ г. & 1993 г. & 1995 г. & 1996 г. & 1998 г. & 1999 г. & 2000 г. & 2002 г. & 2010 г. & 2021 г. \\
\hline \multicolumn{11}{|l|}{ Районы: } \\
\hline Ижемский & 1,9 & 1,9 & 2 & 2 & 2 & 2 & 2,1 & 2,1 & 2,1 & 2,1 \\
\hline Княжпогостский & 3,1 & 2,9 & 2,9 & 2,9 & 2,9 & 2,8 & 2,8 & 2,9 & 2,6 & 2,3 \\
\hline Койгородский & 1 & 1 & 1 & 1 & 0,9 & 0,9 & 0,9 & 1 & 0,9 & 0,9 \\
\hline Корткеросский & 2,1 & 2,2 & 2,2 & 2,2 & 2,2 & 2,2 & 2,3 & 2,3 & 2,2 & 2,2 \\
\hline Прилузский & 2,3 & 2,3 & 2,4 & 2,4 & 2,4 & 2,5 & 2,5 & 2,4 & 2,3 & 2 \\
\hline Сыктывдинский & 2,2 & 2,3 & 2,3 & 2,3 & 2,4 & 2,4 & 2,4 & 2,4 & 2,5 & 3 \\
\hline Сысольский & 1,5 & 1,5 & 1,6 & 1,6 & 1,6 & 1,6 & 1,6 & 1,7 & 1,6 & 1,5 \\
\hline Троицко-Печорский & 2 & 2 & 2 & 2 & 1,8 & 1,8 & 1,8 & 1,7 & 1,5 & 1,3 \\
\hline Удорский & 3 & 2,6 & 2,3 & 2,5 & 2,6 & 2,6 & 2,6 & 2,5 & 2,3 & 2 \\
\hline Усть-Вымский & 3,3 & 3,3 & 3,3 & 3,3 & 3,3 & 3,4 & 3,4 & 3,3 & 3,3 & 3 \\
\hline Усть-Куломский & 3,1 & 3,2 & 3,2 & 3,2 & 3,2 & 3,2 & 3,2 & 3,2 & 3 & 2,8 \\
\hline Усть-Цилемский & 1,4 & 1,4 & 1,4 & 1,5 & 1,5 & 1,5 & 1,5 & 1,5 & 1,4 & 1,3 \\
\hline
\end{tabular}

Источники: Республика Коми в цифрах. 1992-2021. Сыктывкар: Комистат, 1992-2021.

Примечание. Данные текущего учета приведены на 1 января соответствующего года. В 2002 и 2010 гг. - данные Всероссийских переписей населения.

Во многом схожие тенденции изменения средней плотности населения и плотности сельского населения наблюдались в разрезе низовых административных районов республики. Наиболее существенно показатели средней плотности населения изменились в низовых административных районах с преобладанием городского населения. В период с 1991 по 2021 г. наиболее значительное снижение средней плотности населения произошло в городах республиканского значения Воркута (в 2,9 раза), Инта (в 2,6 раза), Вуктыл (в 2,4 раза), Печора (в 1,9 раза), Усинск (в 1,7 раза), Сосногорск (в 1,5 раза) с подчиненными им территориями. В рассматриваемый период увеличение средней плотности населения было зафиксировано только в одном низовом административном районе - городе республиканского значения Сыктывкаре с подчиненной ему территорией, в котором она увеличилась с 343,2 до 370,4 чел. на 1 кв. км, или на 7,3 \%. Среди районов самым значительным стало двухкратное снижение средней плотности в Княжпогостком и Удорском районах (табл. 14).

По территориальной концентрации населения среди низовых районов республики резко выделяются города республиканского значения Сыктывкар, Воркута, Печора, Сосногорск и Ухта с подчиненными им территориями, Сыктывдинский и Усть-Вымский районы, в которых средняя плотность населения в 2021 г. была выше среднереспубликанского показателя (два человека на 1 кв. км). В двух низовых административных районах (города республиканского значения Печора с подчиненной ему территорией и Сысольский район) средняя плотность населения варьировалась в пределах от 1,6 до двух человек на 1 кв. км, в двух (город Усинск с подчиненной ему территорией и Прилузский район) - от 1,1 до 1,5 чел., в шести (город Инта с подчиненной ему территорией, Ижемский, Княжпогостский, Койгородский, Корткеросский и Усть-Куломский районы) - от 0,6 до одного человека на 1 кв. км и в четырех (город Вуктыл с подчиненной ему территорией, Троицко-Печорский, Удорский и Усть-Цилемский районы) - от 0,3 до 0,5 чел. на 1 кв. км.

Таблица 14

Изменение средней плотности населения низовых административных районов

Республики Коми в 1991-2021 г2., тыс. чел.

\begin{tabular}{|l|c|c|c|c|c|c|c|c|c|c|c|}
\hline \multicolumn{1}{|c|}{ Города и районы } & 1991 г. & 1993 г. & 1995 г. & 1996 г. & 1998 г. & 1999 г. & 2000 г. & 2002 г. & 2010 г. & 2021 г. \\
\hline Республика Коми, всего & $\mathbf{3}$ & $\mathbf{3}$ & $\mathbf{2 , 9}$ & $\mathbf{2 , 8}$ & $\mathbf{2 , 8}$ & $\mathbf{2 , 8}$ & $\mathbf{2 , 7}$ & $\mathbf{2 , 4}$ & $\mathbf{2 , 2}$ & $\mathbf{2}$ \\
\hline Города республиканского значения с подчиненными им территориями: \\
\hline Сыктывкар & 343,2 & 346,6 & 350,4 & 351,7 & 353,7 & 354 & 352,3 & 351,1 & 358,4 & 370,4 \\
\hline Воркута & 9 & 8,7 & 8 & 7,6 & 7,3 & 7,1 & 7 & 5,5 & 4 & 3,1 \\
\hline Вуктыл & 1,2 & 1,2 & 1,1 & 1,1 & 1,1 & 1,1 & 1,1 & 0,8 & 0,7 & 0,5 \\
\hline Инта & 2,3 & 2,3 & 2,2 & 2,1 & 2,1 & 2 & 2 & 1,5 & 1,2 & 0,9 \\
\hline Печора & 3,2 & 3,2 & 3,1 & 3,1 & 3 & 3 & 2,9 & 2,3 & 2 & 1,7 \\
\hline Сосногорск & 3,8 & 3,8 & 3,7 & 3,7 & 3,6 & 3,6 & 3,5 & 3,2 & 2,8 & 2,6 \\
\hline Усинск & 2,4 & 2,3 & 2,2 & 2,1 & 2 & 2 & 2 & 1,7 & 1,5 & 1,4 \\
\hline Ухта & 10,8 & 10,7 & 10,3 & 10,1 & 9,8 & 9,7 & 9,5 & 9,6 & 9,2 & 8,5 \\
\hline
\end{tabular}


Окончание табл. 14

\begin{tabular}{|c|c|c|c|c|c|c|c|c|c|c|}
\hline Города и районы & 1991 г. & 1993 г. & 1995 г. & 1996 г. & 1998 г. & 1999 г. & 2000 г. & 2002 г. & 2010 г. & 2021 г. \\
\hline \multicolumn{11}{|l|}{ Районы: } \\
\hline Ижемский & 1,3 & 1,3 & 1,3 & 1,3 & 1,3 & 1,3 & 1,3 & 1,2 & 1 & 0,9 \\
\hline Княжпогостский & 1,6 & 1,5 & 1,4 & 1,4 & 1,3 & 1,3 & 1,3 & 1,2 & 1 & 0,8 \\
\hline Койгородский & 1,2 & 1,2 & 1,1 & 1,1 & 1 & 1 & 1 & 1 & 0,8 & 0,7 \\
\hline Корткеросский & 1,4 & 1,4 & 1,4 & 1,3 & 1,3 & 1,3 & 1,3 & 1,2 & 1 & 0,9 \\
\hline Прилузский & 2,2 & 2,2 & 2,2 & 2,2 & 2,2 & 2,1 & 2,1 & 1,9 & 1,6 & 1,2 \\
\hline Сыктывдинский & 3,7 & 3,8 & 3,8 & 3,7 & 3,7 & 3,7 & 3,7 & 3,3 & 3,1 & 3,3 \\
\hline Сысольский & 3,2 & 3,2 & 3,1 & 3,1 & 3 & 3 & 3 & 2,8 & 2,3 & 2 \\
\hline Троицко-Печорский & 0,6 & 0,6 & 0,6 & 0,6 & 0,5 & 0,5 & 0,5 & 0,4 & 0,3 & 0,3 \\
\hline Удорский & 1 & 0,9 & 0,8 & 0,8 & 0,8 & 0,8 & 0,8 & 0,7 & 0,6 & 0,5 \\
\hline Усть-Вымский & 8,8 & 8,5 & 8,3 & 8,3 & 8,1 & 8,1 & 8 & 7,1 & 6,1 & 5,1 \\
\hline Усть-Куломский & 1,5 & 1,5 & 1,4 & 1,4 & 1,4 & 1,4 & 1,4 & 1,2 & 1 & 0,9 \\
\hline Усть-Цилемский & 0,4 & 0,4 & 0,4 & 0,4 & 0,4 & 0,4 & 0,4 & 0,4 & 0,3 & 0,3 \\
\hline
\end{tabular}

Составлено и рассчитано по: Республика Коми в цифрах. 1992--2021. Сыктывкар: Комистат, 1992-2021.

Примечание. Данные текущего учета приведены на 1 января соответствующего года. В 2002 и 2010 гг. - данные Всероссийских переписей населения.

За 30 лет постсоветского периода людность увеличилась только в столице республики г. Сыктывкаре. Относительная стабилизации наблюдалась в селах-райцентрах Выльгорте, Ижме, Корткеросе и Объячево. В остальных административных центрах низовых административных районов численность населения непрерывно снижалась. Между тенденции изменения абсолютной численности населения административных центров чаще всего не совпадали с тенденциями изменения их удельного веса в населении низового административного центра. По сравнению с 1991 г. в 17 из 20 административных центрах наблюдалось непрерывное увеличение удельного веса административного центра в населении низового административного района. Исключение составили города республиканского значения Воркута и Инта с подчиненными им территориями, а также Сыктывдинский район, в которых после 2010 г. произошло небольшое снижение доли административного центра.

С 1991 по 2021 г. общая численность проживающих в селах - районных центрах снизилась с 53,5 до 49,8 тыс. чел., а их удельный вес в сельском населении республики увеличился с 17,6 до 28,2 \%. На начало 2021 г. самыми людными селами - районными центрами с населением свыше 5 тыс. чел. были Выльгорт (10,3 тыс.), Визинга (6,8 тыс.), Объячево (5,7 тыс.), Усть-Кулом (5,1 тыс.). В остальных шести селах - райцентрах (Айкино, Ижма, Койгородок, Корткерос, Кослан, Усть-Цильма) людность была менее 5 тыс. чел. Самое малолюдное село - райцентр - Кослан, в котором на 1 января 2021 г. проживало 2,3 тыс. чел. По уровню концентрации населения в административном центре района выделялись Сысольский (55,9 \%), Усть-Цилемский $(44,4$ \%), Сыктывдинский $(42,1 \%)$ и Койгородский $(41,1 \%)$ районы. В Ижемском, Корткеросском, Прилузском и Усть-Куломском районах доля административного центра в населении района варьировалась от 20 до 35 \%, в Удорском и Усть-Вымском районе - от 10 до 15 \% (табл. 15).

Таблица 15

Изменение удельного веса административных центров в численности населения низовых административных районов Республики Коми в 1991-2021 22.

\begin{tabular}{|c|c|c|c|c|c|c|c|c|c|c|}
\hline \multirow[t]{2}{*}{ Города и районы } & \multicolumn{5}{|c|}{$\begin{array}{c}\text { Людность административных центров, } \\
\text { тыс. чел. }\end{array}$} & \multicolumn{5}{|c|}{$\begin{array}{c}\text { Удельный вес в населении } \\
\text { административного района, \% }\end{array}$} \\
\hline & 1991 г. & 1995 г. & 2002 г. & 2010 г. & 2021 г. & 1991 г. & 1995 г. & 2002 г. & 2010 г. & $2021 г$. \\
\hline \multicolumn{11}{|c|}{ Города республиканского значения с подчинёнными им территориями: } \\
\hline Сыктывкар & 224 & 229 & 230 & 235 & 243,9 & 93,2 & 93,4 & 93,6 & 93,7 & 94,1 \\
\hline Воркута & 117,1 & 101,1 & 84,9 & 70,5 & 52,3 & 54 & 52,5 & 63,3 & 73,6 & 70,3 \\
\hline Вуктыл & 19,4 & 19 & 14,5 & 12,4 & 9,7 & 71,1 & 73,6 & 78,9 & 83,1 & 85,7 \\
\hline Инта & 62,5 & 57,6 & 41,2 & 32,1 & 23,7 & 89 & 88,2 & 88,8 & 91,2 & 90 \\
\hline Печора & 66,5 & 63,8 & 48,7 & 43,1 & 37,6 & 71,1 & 70,4 & 73,5 & 75,1 & 78,4 \\
\hline Сосногорск & 30,7 & 31,5 & 29,6 & 27,8 & 25,8 & 49 & 51,7 & 56,4 & 59,3 & 61,1 \\
\hline Усинск & 52,5 & 50,3 & 45,4 & 40,8 & 37,2 & 72,7 & 76,1 & 85,8 & 86,4 & 86,7 \\
\hline Ухта & 114,5 & 106,8 & 103,3 & 99,6 & 92,5 & 80,7 & 78,7 & 81,1 & 81,8 & 82,4 \\
\hline
\end{tabular}


Окончание табл. 15

\begin{tabular}{|c|c|c|c|c|c|c|c|c|c|c|}
\hline \multirow[t]{2}{*}{ Города и районы } & \multicolumn{5}{|c|}{$\begin{array}{c}\text { Людность административных центров, } \\
\text { тыс. чел. }\end{array}$} & \multicolumn{5}{|c|}{$\begin{array}{c}\text { Удельный вес в населении } \\
\text { административного района, \% }\end{array}$} \\
\hline & 1991 г. & 1995 г. & 2002 г. & 2010 г. & 2021 г. & 1991 г. & 1995 г. & 2002 г. & 2010 г. & $2021 \Gamma$. \\
\hline \multicolumn{11}{|l|}{ Районы: } \\
\hline Ижемский & 3,7 & 3,9 & 3,8 & 3,6 & 3,8 & 15,5 & 16,1 & 17,6 & 19 & 22,2 \\
\hline Княжпогостский & 18,1 & 17,2 & 16,7 & 14,6 & 12,4 & 46,4 & 49,3 & 56,4 & 62,2 & 67,1 \\
\hline Койгородский & 3 & 3 & 3,1 & 2,9 & 2,9 & 24,6 & 25,4 & 30,7 & 34,9 & 41,1 \\
\hline Корткеросский & 4,4 & 4,5 & 4,7 & 4,6 & 4,6 & 16,2 & 16,9 & 19,7 & 23,5 & 26 \\
\hline Прилузский & 5,4 & 6,1 & 5,8 & 5,7 & 5,7 & 18,6 & 21,1 & 23,6 & 27,5 & 34,7 \\
\hline Сыктывдинский & 10,5 & 11,3 & 10,2 & 10,3 & 10,3 & 38,2 & 40,5 & 42,1 & 45,4 & 42,1 \\
\hline Сысольский & 7,3 & 7,3 & 7,1 & 6,8 & 6,8 & 37,6 & 38,4 & 42,3 & 48,8 & 55,9 \\
\hline Троицко-Печорский & 13,1 & 10,2 & 8,9 & 7,3 & 5,9 & 50,8 & 43,6 & 50,3 & 52,3 & 57,3 \\
\hline Удорский & 4 & 4,3 & 2,7 & 2,3 & 2,3 & 10,8 & 15,8 & 10,7 & 11,2 & 13,7 \\
\hline Усть-Вымский & 3,7 & 3,6 & 3,5 & 3,4 & 3,4 & 8,8 & 9 & 10,4 & 11,4 & 13,7 \\
\hline Усть-Куломский & 6,1 & 5,6 & 5,5 & 5,1 & 5,1 & 15,5 & 14,8 & 17 & 19,1 & 22,2 \\
\hline Усть-Цилемский & 5,4 & 5,5 & 5,1 & 4,9 & 4,9 & 31,6 & 31,6 & 33 & 37,4 & 44,4 \\
\hline
\end{tabular}

Составлено и рассчитано по: Республика Коми в цифрах. 1992-2021. Сыктывкар: Комистат, 1992-2021.

Примечание. Данные текущего учета приведены на 1 января соответствующего года. В 2002 и 2010 гг. - данные Всероссийских переписей населения.

В 1990-е гг. продолжалось сокращение численности населения районов Дальнего и Среднего Севера вследствие усиления миграционного оттока населения из северных городов и поселков городского типа республики за пределы региона и в районы Ближнего Севера в пределах республики. С 1991 по 2021 г. численность проживающих на Дальнем Севере сократилась с 359,2 до 143,6 тыс. чел., на Среднем Севере - с 492,2 до 268,6 тыс. чел., что в относительном выражении составило соответственно 60 и 45,4 \%. При этом удельный вес районов Дальнего Севера в численности населении Республики Коми уменьшился с 28,4 до 17,6 \%, а Среднего Севера - с 33,9 до 33 \%. Несмотря на уменьшение абсолютной численности населения Ближнего Севера с 1991 по 2021 г. с 476,3 до 401,4 тыс. чел., удельный вес районов Ближнего Севера в населении республики повысился с 37,7 до 49,4 \% (табл. 16).

Проведенный детальный анализ сдвигов в размещении населения Республики Коми в разрезе низовых административных районов и подзон Российского Севера в вековой период с 1920 по 2020 г. включительно позволил сделать следующие основные выводы. На сдвиги в размещении населения и формирование территориальной структуры населения Республики Коми существенное влияние оказали изменения динамики численности и режима воспроизводства населения, направленности миграционных процессов и темпов урбанизации, уровня освоенности и степени заселенности территории в результате взаимодействия экономических и социальных факторов, изменения характера использования природно-ресурсного потенциала территории и специализации регионального хозяйственного комплекса.

Распределение населения Республики Коми по подзонам Севера в 1991-2021 22.

Таблица 16

\begin{tabular}{|c|c|c|c|c|c|c|c|c|}
\hline \multirow{3}{*}{ Годы } & \multirow{2}{*}{\multicolumn{2}{|c|}{ Республика Коми }} & \multicolumn{6}{|c|}{ Подзоны Севера } \\
\hline & & & \multicolumn{2}{|c|}{ Дальний Север } & \multicolumn{2}{|c|}{ Средний Север } & \multicolumn{2}{|c|}{ Ближний Север } \\
\hline & Тыс. чел. & $\%$ & Тыс. чел. & В \% к РК & Тыс. чел. & В \% к РК & Тыс. чел. & В \% к РК \\
\hline 1991 & 1264,7 & 100 & 359,2 & 28,4 & 429,2 & 33,9 & 476,3 & 37,7 \\
\hline 1993 & 1245,7 & 100 & 349,8 & 28,1 & 419,5 & 33,7 & 476,4 & 38,2 \\
\hline 1995 & 1201,6 & 100 & 324 & 27 & 405,3 & 33,7 & 472,3 & 39,3 \\
\hline 1996 & 1185,6 & 100 & 312 & 26,3 & 402,9 & 34 & 470,7 & 39,7 \\
\hline 1998 & 1160,7 & 100 & 299,4 & 25,8 & 393,7 & 33,9 & 467,6 & 40,3 \\
\hline 1999 & 1149,2 & 100 & 294,2 & 25,6 & 388,5 & 33,8 & 466,5 & 40,6 \\
\hline 2000 & 1134,6 & 100 & 288 & 25,4 & 382,3 & 33,7 & 464,3 & 40,9 \\
\hline 2002 & 1018,7 & 100 & 233,4 & 22,9 & 344,1 & 33,8 & 441,2 & 43,3 \\
\hline 2010 & 901,2 & 100 & 178,3 & 19,8 & 306,8 & 34 & 416,1 & 46,2 \\
\hline 2021 & 813,6 & 100 & 143,6 & 17,6 & 268,6 & 33 & 401,4 & 49,4 \\
\hline
\end{tabular}

Составлено и рассчитано по: Республика Коми в цифрах. 1992-2021. Сыктывкар: Комистат, 1992-2021.

Примечание. Данные текущего учета приведены на 1 января соответствующего года. В 2002 и 2010 гг. - данные Всероссийских переписей населения. 
Вслед за кардинальной сменой характера динамики численности населения рост демографического потенциала региона и сдвиг производительных сил в северные города и районы Дальнего и Среднего Севера под влиянием взаимосвязанных процессов индустриализации и урбанизации в начале 1990-х г. сменился на депопуляцию и отток населения с повышением доли районов Ближнего Севера в общей численности населения Республики Коми. Одновременно с этим наблюдается постепенное стягивание населения в административные центры низовых административных районов за счет периферийных территорий. К настоящему времени эти изменения в расселении населения региона приобрели характер долговременных тенденций, которые будут определять направленность дальнейшей трансформации территориальной структуры населения в ближайшие десятилетия.

\section{Источники и литература}

1. Безносова Н.П. Численность населения Коми автономной области в 1926 году: проблема отсутствия единства данных в источниках и историографии // Известия Коми научного центра УрО РАН. Сыктывкар, 2017. № 4 (32). С. 89.

2. Обедков А.П. Административно-территориальное деление Республики Коми в системе территориальногосударственной организации России: история, теория, практика. Сыктывкар: КГПИ, 2000. С. 24, 48, 49, 52-58.

3. Коми область. Статистический справочник. Сыктывкар: Коми обл. стат. отдел, 1929. С. 7.

4. Материалы по статистике населения, народного просвещения и жилищного строительства Северного края. Архангельск, 1930. С. 8.

5. Жеребцов И.Л., Безносова Н.П. Динамика численности и источники формирования населения Республики Коми в 1926-1940 гг. // Уральский исторический вестник. 2017. № 4 (57). С. 78.

6. Республика Коми к 50-летию победы в Великой Отечественной войне. Сыктывкар: Коми кн. изд-во, 1995. C. 57 .

7. Республика Коми: Энциклопедия. Сыктывкар: Коми кн. изд-во, 1997. Т. 1. С. 57.

8. Обедков А.П. География населения Республики. Ухта: Институт управления, информации и бизнеса, 2005. C. 7. 


\title{
ИСТОРИОГРАФИЯ, ИСТОЧНИКИ, МЕТОДОЛОГИЯ
}

УДК 913.908. (091):914.7

DOI: 10.19110/2304-5922-2021-1-46-49

\author{
В.И. Силин* \\ Хозяйство Архангельской губернии и поселения \\ по Печоре и Ижме по данным старых карт
}

В статье приводятся статистические данные по хозяйству и населению Архангельской губернии на основе анализа «Генеральной карты Архангельской губернии» 1797 г. Отдельно рассмотрена поселенческая структура по нижнему течению рек Печора и Ижма. Приведены данные о селениях, существовавших на этих территориях в коние XVIII - начале XIX в. с привлечением данньх из Атласа Российской империи 1818 2.

Ключевые слова: карта, Архангельская губерния, Печора, Ижма, Ф. Киселев

\section{V.I. Silin}

\section{The economy of the Arkhangelsk province and settlements in Pechora and Izhma according to old maps}

The article presents statistical data on the economy and population of the Arkhangelsk province based on the analysis of the "General Map of the Arkhangelsk Province» of 1797. The settlement structure of the Lower Pechora and Izhma is considered separately. The data on the villages that existed in these territories at the end of the XVIII - beginning of the XIX century are presented, using data from the Atlas of the Russian Empire of 1818 .

Key words: map, Arkhangelsk province, Pechora, Izhma, F. Kiselyov

Предыдущие публикации были посвящены истории возникновения и существования населенных пунктов на Печоре и Ижме $[1,2]$. В данной статье рассматриваются структура населенных пунктов и некоторые статистические данные по двум старым картам.

В 1797 г. вышла «Генеральная карта Архангельской губернии» в масштабе 60 верст в английском дюйме, составленная губернским землемером титулярным советником Федором Киселевым (рис. 1). Карта красиво оформлена: в левом нижнем углу на фоне классического городского здания стоят на рейде парусное судно (по строению похоже на каравеллы Колумба) и поморский карбас (коч?), приведены названия территорий, граничащих с Архангельской губернией: Выборгская губерния; Сердобольский уезд; Шведская Лапландия; Норвегская Лапландия; Северный океан и Карское море; Тобольская губерния, Березовский уезд; Вологодской губернии, Устьсысольский, Яренский, Красногорский, Вельский уезды; Новгородской губернии, Каргопольский, Вытегорский уезды; Онего Озеро; Петрозаводский уезд.

В правой стороне карты мы видим двух ангелов с символами власти, один держит скипетр, другой корону. Под ними автор приводит герб Архангельской губернии и семь гербов уездных центров. В правом нижнем углу карты - количественные данные по характеристике населения и хозяйства губернии и уездов. Поскольку территория Печоры и Ижмы входила тогда в Мезенский уезд, поэтому мы приводим сведения по губернии в целом и по Мезенскому уезду. Эти сведения позволяют сейчас составить представление о хозяйстве того времени. Данные приводятся, как указано на карте, по последней произведенной в губернии реви-

\footnotetext{
* Силин Владимир Иванович (Сыктывкар) - доктор географических наук, главный научный сотрудник сектора историкодемографических и историко-географических исследований Российского Севера Института языка, литературы и истории Коми НЦ УрО РАН, silinv@rambler.ru.
} 
зии. 23 июня 1794 г. был издан именной указ о проведении Пятой ревизии, которая должна быть завершена к началу 1796 г. Формуляры документов остались такими же, как и во время Четвертой ревизии. Поэтому можно предположить, что данные с карты соответствуют этому времени.

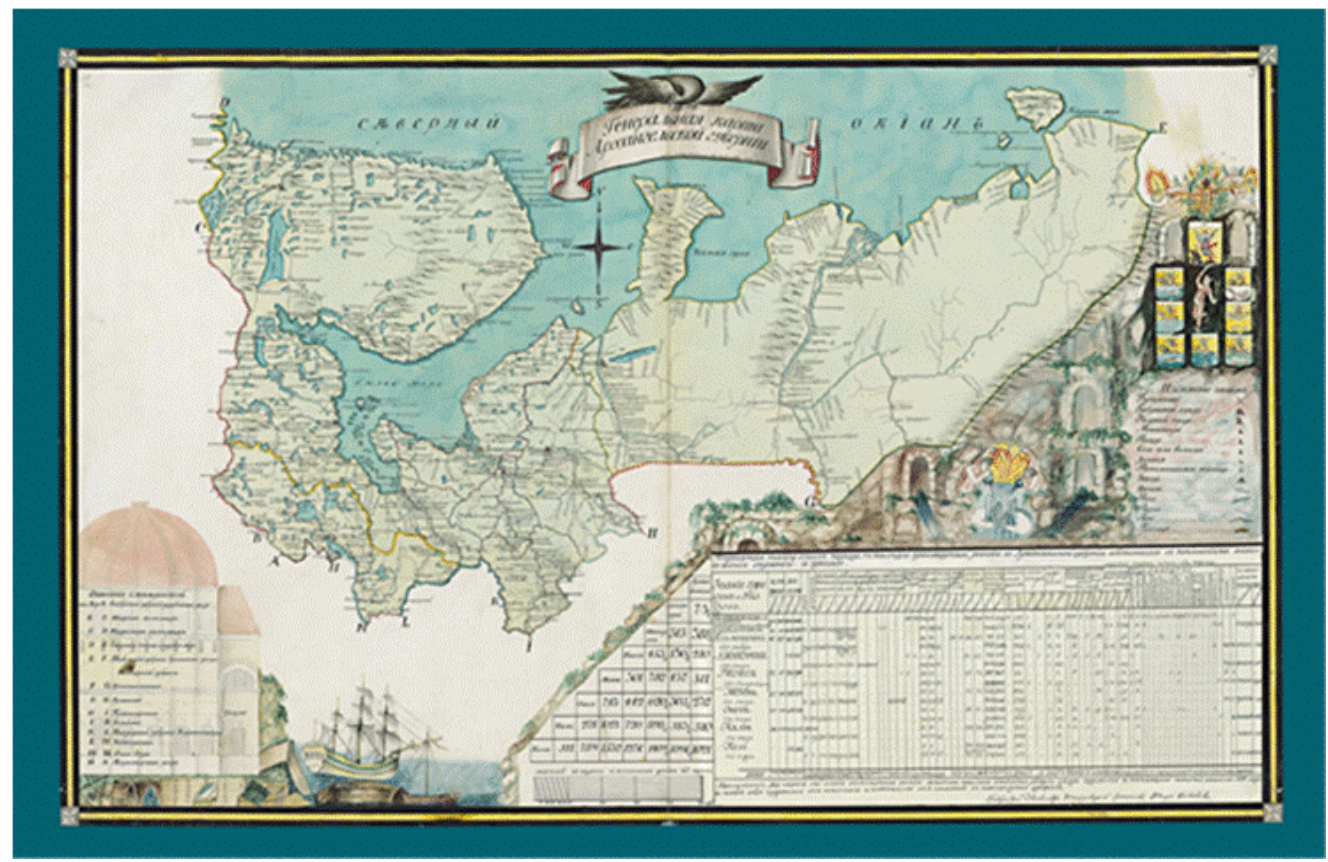

Рис. 1. Карта Архангельской губернии 1797 г.

Статистические данные по Архангельской губернии на 1797 г.

\begin{tabular}{|c|c|c|c|}
\hline \multirow{2}{*}{\begin{tabular}{|l} 
Купцов \\
\end{tabular}} & & Архангельская губерния & Мезенский уезд \\
\hline & $\begin{array}{l}\text { муж. } \\
\text { жен. }\end{array}$ & $\begin{array}{l}776 \\
788\end{array}$ & $\begin{array}{l}60 \\
48\end{array}$ \\
\hline Мещан & $\begin{array}{l}\text { муж. } \\
\text { жен. }\end{array}$ & $\begin{array}{ll}4 & 802 \\
5 & 155\end{array}$ & $\begin{array}{l}583 \\
720\end{array}$ \\
\hline \multicolumn{2}{|l|}{ Сел } & 230 & 16 \\
\hline \multicolumn{2}{|l|}{ Деревень } & 2907 & 119 \\
\hline Экономических крестьян & $\begin{array}{l}\text { муж. } \\
\text { жен. }\end{array}$ & $\begin{array}{l}18911 \\
21274\end{array}$ & $\begin{array}{l}217 \\
220\end{array}$ \\
\hline Черносошных крестьян & $\begin{array}{l}\text { муж. } \\
\text { жен. }\end{array}$ & $\begin{array}{l}42669 \\
47247\end{array}$ & $\begin{array}{l}7909 \\
9170\end{array}$ \\
\hline Дворцовых & $\begin{array}{l}\text { муж. } \\
\text { жен. }\end{array}$ & $\begin{array}{l}19472 \\
20757\end{array}$ & $\begin{array}{l}- \\
-\end{array}$ \\
\hline Ясашных самоядей & $\begin{array}{l}\text { муж. } \\
\text { жен. }\end{array}$ & $\begin{array}{l}1603 \\
1452\end{array}$ & $\begin{array}{l}1603 \\
1452\end{array}$ \\
\hline Отписных крестьян & $\begin{array}{l}\text { муж. } \\
\text { жен. }\end{array}$ & $\begin{array}{l}4 \\
5\end{array}$ & $\begin{array}{l}- \\
-\end{array}$ \\
\hline Дворовых людей & $\begin{array}{l}\text { муж. } \\
\text { жен. }\end{array}$ & $\begin{array}{l}76 \\
89 \\
\end{array}$ & $\begin{array}{l}- \\
-\end{array}$ \\
\hline Церковнослужителей & $\begin{array}{l}\text { муж. } \\
\text { жен. }\end{array}$ & $\begin{array}{l}1485 \\
1940\end{array}$ & $\begin{array}{l}141 \\
165\end{array}$ \\
\hline Отставных от службы & муж. & 295 & 22 \\
\hline Кузниц медногодных? & & 11 & - \\
\hline Кузниц железогодных & & 227 & - \\
\hline Корабельных верфей & & 7 & - \\
\hline Заводов сахарных & & 1 & - \\
\hline Заводов медоваренных & & 1 & - \\
\hline Заводов для двоения водо & & 1 & - \\
\hline
\end{tabular}


Окончание таблиць

\begin{tabular}{|l|c|c|}
\hline & Архангельская губерния & Мезенский уезд \\
\hline Заводов пивоваренных & 20 & - \\
\hline Заводов солодованных & 7 & - \\
\hline Заводов сушиленных & 6 & - \\
\hline Заводов сальных свеч & 2 & - \\
\hline Заводов пеноваренных & 3 & - \\
\hline Заводов мыловаренных & 7 & - \\
\hline Салотопень говяжьих & 6 & - \\
\hline Салотопень ворванных & 5 & - \\
\hline Заводов коптиленных & 2 & - \\
\hline Заводов смольных & 6 & - \\
\hline Заводов каменной посуды & 1 & 142 \\
\hline Заводов кирпичных & 8 & 2 \\
\hline Соляных варниц & 30 & 39637350 \\
\hline Мостов & 1586 & - \\
\hline Перевозов & 86 & - \\
\hline Поначислению площади в десятинах & 82187461 & \\
\hline
\end{tabular}

Источник: Карта Архангельской губернии 1797 года.

На Генеральной карте приведены населенные пункты (от устья р. Печоры) (рис. 2).

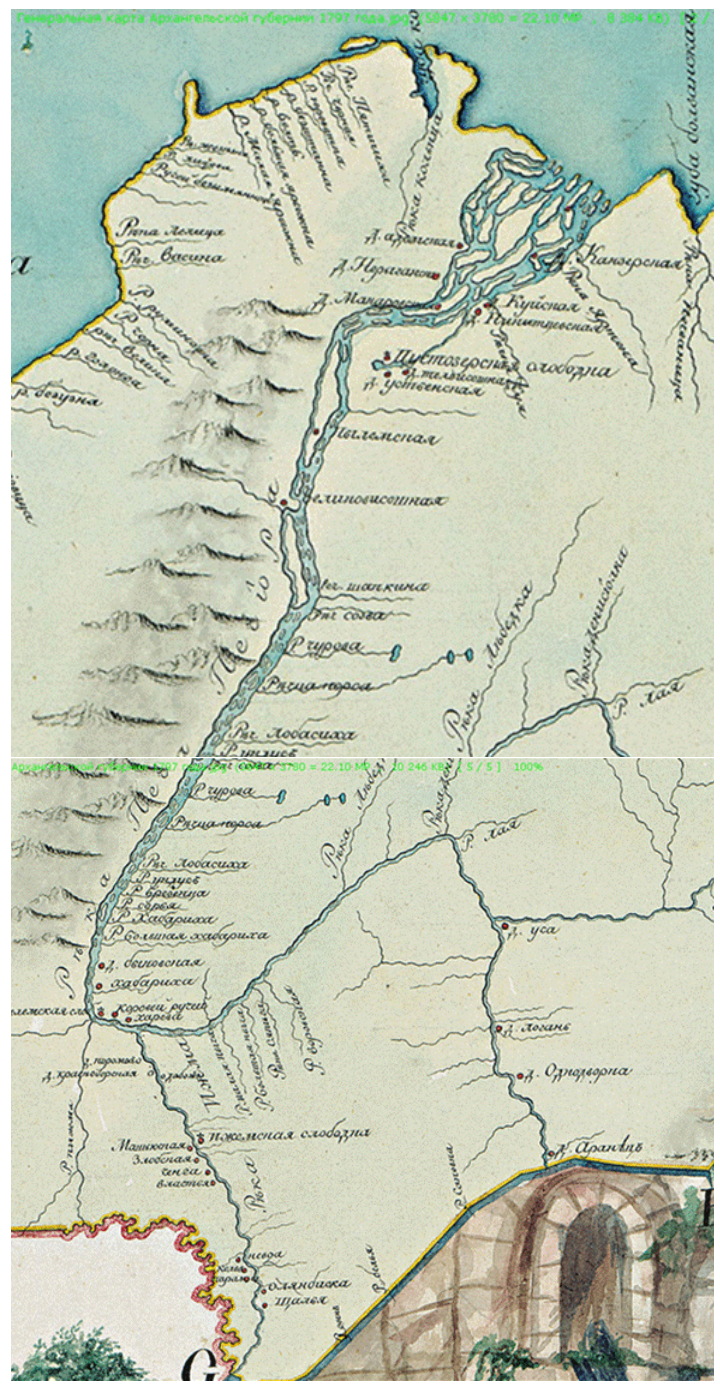

Рис. 2. Населенные пункты по Нижней Печоре, Средней Печоре и Ижме. 
Генеральная карта... 1797 г. Атлас Российской империи 1818 г.

$\begin{array}{ll}\text { Канзерская } & \text { Конзера } \\ \text { Адемская } & \text { Адемская } \\ \text { Норыганская } & \text { Норыганская } \\ \text { Куйская } & \text { Куйская } \\ \text { Никитиевская } & \\ \text { Макаровская } & \\ \text { Пустозерская слободка } & \text { Пустозерская } \\ \text { Тельвисошная } & \text { Пылемская } \\ \text { Быковская } & \text { Лобиская } \\ \text { Хабариха } & \text { Великовилошная } \\ \text { Устьцилемская слобода } & \text { Быковская } \\ \text { Коровий ручей } & \text { Усть-Телемская на Цильме д. Цилемской } \\ \text { Харева } & \\ \text { По Печоре: } & \\ \text { Уса } & \\ \text { Погань } & \\ \text { Однодворная } & \\ \text { Аранец } & \\ \text { По Ижме: } & \\ \text { Поромос? } & \\ \text { Красноборская } & \text { Оранец } \\ \text { Дабож? } & \\ \text { Ижемская слободка } & \\ \text { Машьюгская } & \\ \text { Злобская } & \\ \text { Ченга } & \\ \text { Властья } & \text { Невда } \\ \text { Колва } & \\ \text { Парам } & \\ \text { Олябиска } & \\ \text { Щалья } & \\ \text { (Названия дань в соответствии с картой) } \\ \text { Возможноская }\end{array}$

Возможно, что на карте показаны не все существовавшие в то время деревни, как и на последующих мелкомасштабных картах. Например, в Атласе Российской империи по новейшему разделению на губернии и области (1807-1818). № 5. Карта губерний Архангельской, Олонецкой и Вологодской. 1818 г. (вторая колонка).

Наиболее информативная, относительно населенных пунктов - карта Боровского [1], но там нет указания на время их возникновения, эти данные приводятся в работе [2].

\section{Источники и литература}

1. Силин В.И. Карта Печорского края, составленная Боровским в 1853 г. как демографический источник // Историческая демография. 2019. № 2 (24). С. 75-77.

2. Силин В.И. История заселения бассейна реки Ижма // География: Развитие науки и образования. Коллективная монография по материалам Всероссийской с международным участием конференции LXXII Герценовские чтения (18-21 апреля 2021 г.). СПб., 2019. С. 406-410. 


\section{B.M. Теребихин ${ }^{*}$}

\section{Антропологический кризис как интегральная оценка демосоциального развития Республики Коми в период социетальной трансформации (ревореформ) 1991-1995 гг.}

В статье осущзествлен системный анализ процессов демосоциильного развития региона в 1991-1995 г2., сделан вывод, что интегральной оценкой соичоантропологического развития Республики Коми в период социетальной трансформации (ревореформ) являлся социогуманитарный (антропологический) кризис.

Ключевые слова: антропологический (социогуманитарный) кризис, демосоцииальное развитие

\section{V.M. Terebikhin}

\section{Anthropological crisis as an integral assessment of the demosocial development of the Komi Republic during the period of societal transformation (re-reform) of 1991-1995}

The article provides a systematic analysis of the processes of demosocial development of the region in 19911995, it is concluded that the socio-humanitarian (anthropological) crisis was an integral assessment of the socio-anthropological development of the Komi Republic during the period of societal transformation (re-reform).

Key words: anthropological (socio-humanitarian) crisis, demosocial development

«Вы спросите, для чего я читал эту лекцию, какой в ней толк? Что, я наслаждаюсь несчастьем русского народа? Нет, здесь есть жизненный расчет ... это есть долг нашего достоинства сознать то, что есть. Но мы жить все-таки будем! Следовательно, для будущего нам полезно иметь о себе представление».

Иван Павлов. Лекция «О русском уме». 1918 год

Системный анализ процессов демосоциального развития региона за последние 100 -летие позволяет сделать вывод, что в период спонтанной ревореформы, «социотрясения» (Грушин) 1991-1995 гг. в республике, как и в России в целом, сформировался антропологический (социогуманитарный) кризис. Антропологический (социогуманитарный) кризис, как антропосоциетальный процесс, многоаспектный, поликомпонентный, интегральный антропофеномен, антропогенная реальность, форма отражения антропоситуации, интегративная оценка состояния региона и характеристика кризиса человеческого развития, концептуализируется автором как «системокомплекс» деструктивных, синхронизированных по времени возникновения и протекания, относительно самостоятельных, но при этом когерентных, всесторонне взаимозависимых флуктуаций функционирующих в регионе антропокризисов: «демографического кризиса» (кризиса воспроизводства населения, «популяционной катастрофы» (Л.А. Попова), кризиса смертности, кризиса популяционного здоровья, духовно-нравственного кризиса, социопсихологического кризиса, комплекса кризисов идентичности, телеологического кризиса (кризиса цели), аксиологического, «экзистенциального кризиса» (В.В. Пастухов), «нравственной и интеллектуальной деградации общества» (В.Е.Лепский), кризиса межпоколенческой солидарности, кризиса семейных отношений, системы воспитания граждан, морального контроля, снижение «качества качеств» населения, доминирование негативных антропотенденций над позитивными

Антропокризис - это своеобразный «разрыв постепенности», относительной устойчивости демосоциального развития, стабильного состояния демосоциальной сферы, резкое кризисное изменение жизнестратегий большинства населения, изменение процесса эволюционного, относительно стабильного человеческого развития в регионе в 1960-1980 гг.. Одним из значимых антропокризисов в системе антропологического кризиса являлся так называемый «демографический кризис» - кризис воспроизводства населения, депопу-

\footnotetext{
* Теребихин Владимир Михайлович (Сыктывкар) - кандидат философских наук, эксперт Центра «Наследие» им. Питирима Сорокина, v.terebikhin@mail.ru.
} 
ляция, которая измеряется посредством соотношения общих коэффициентов рождаемости и смертности и выражается величиной естественного отрицательного прироста.

Депопуляция 1991-1995 гг. рассматривается в качестве формы проявления резко нисходящей демографической динамики, как снижение демографического потенциала. Это был более глубокий, многофакторный антропопроцесс, характеризуемый кризисными антропопроявлениями, которые по скорости и негативным масштабам можно номинировать как эпидемию. В 1992 г. депопуляция отмечалась в четырех районах республики. С 1993 г. на смену естественного прироста населения впервые с 1960-1980-х гг. пришла естественная убыль, начался депопуляционный режим воспроизводства населения. «Демографический слом» - депопуляционный режим воспроизводства населения, наступивший в 1993 г. (по Российской Федерации в целом в 1992 г.) был характерен для всех городов и районов кроме Воркуты и Вуктыла. С 1994 г. «депопуляционная зона» расширилась и охватила все муниципальные образования.

Важнейшими специфическими особенностями депопуляции 1990-х гг., по сравнению с другими периодами, в республике, как и в целом в России, явились:

- высокая скорость и синхронность распространения демокризиса по обширной территории региона (от южных до арктических районов);

- синхронизация процессов снижения рождаемости и увеличения смертности, «сверхсмертности», населения (в отличие от многих стран, где отрицательная естественная убыль связана исключительно с низкой рождаемостью);

- качественная деформация структуры населения;

- нарушение всех пороговых, предельно-критических индикаторов демосоциальной безопасности.

Автор в полной мере согласен с оценками основных тенденций демосоциального развития региона в исследуемый период изложенными в основательном монографическом исследовании известного российского демографа Л.А. Поповой, и, прежде всего, в том, что «демографический кризис проявился в Республике Коми острее и глубже, чем в целом по стране. За первые же годы кризиса практически сошли на нет существовавшие ранее позитивные особенности демографического развития республики, обусловленные относительно более молодой возрастной структурой населения, негативные же особенности - еще сильнее углубились» [1, c. 4-5].

За счет резкого падения рождаемости в 1991-1995 гг. в республике потенциально «лишились права на жизнь» 43 тыс. чел.. Если бы рождаемость сохранилась в эти годы на уровне 1990 г., то число родившихся составило бы 101,2 тыс. Из-за существенного снижения за 1991-1995 гг., родилось лишь 58,6 тыс. чел. Уровень рождаемости в середине 1990-х гг. (как и в настоящее время) не соответствовал величине, необходимой для простого замещения поколений родителей их детьми. Низкая рождаемость является фактором, нарушающим стабильность воспроизводственных процессов в регионе.

Вторым, когерентным с кризисом воспроизводства населения, был кризис популяционного здоровья, «кризис смертности». Одной из основных его тенденций и форм проявления являлся антропопроцесс опережения темпов роста смертности над темпами роста заболеваемости, рождаемости и существенном снижении ожидаемой продолжительности жизни населения. С 1991 по 1995 г. смертность населения возросла на 55,7 \%, заболеваемость - на 25 \%. При этом среднегодовой темп прироста смертности составил 9,2 \% (за 19811985 гг. - 0,5\%, 1986-1990 гг. - 2\%), а заболеваемости - 4,6\%.

В демографии пороговым индикатором «кризиса смертности» служит рост коэффициента смертности на 10 \% в год по сравнению с этим показателем в любом из 25 предшествующих лет. В республике данный показатель увеличился с 1991 по 1992 г. на 15 \%, с 1992 по 1993 г. - на 30 \%, с 1993 по 1994 г. - на 12 \%. Коэффициент смертности 1995 г. соответствовал такому же показателю 1954 г. Драйвером смертности явилась эпидемия психических заболеваний и расстройств поведения трудоспособной части населения (в основном мужчин), пик которой пришелся на 1994-1995 гг.

Наиболее значительный разрыв в темпах прироста смертности и заболеваемости наблюдался по таким классам причин смерти и заболеваемости, как несчастные случаи, травмы и отравления, инфекционные и паразитарные заболевания. В 1990-е гг. смертность увеличилась преимущественно за счет экзогенных, так называемых «внешних, неестественных причин смерти» (травм, отравлений убийств, самоубийств, ДТП). Если в цепом за 1991-1995 гг. общий коэффициент смертности от всех классов причин возрос на 58 \% (по России в целом с 1991 по 1994 г. - на 37.6 \%), то по «внешним» причинам, связанным с образом жизни в два раза.

В структуре данных причин смерти число умерших от убийств возросло с 261 случая в 1991 г. до 528 в 1995 г. (в два раза), от самоубийств - соответственно с 451 до 660 (в 1,5 раза), от случайных отравлений алкоголем - с 145 до 882 (в шесть раз). В общей структуре смертности удельный вес умерших от этих причин увеличился с 20 \% в 1991 г. до 25 \% в 1995 г. Уровень смертности по данному классу причин смерти превышал 
соответствующий показатель по России в 1994 г. на 35 \% и был самым высоким среди северных регионов и финно-угорских республик страны и финно-угорских стран. По сравнению с западноевропейскими странами смертность от убийств в республике была больше у мужчин в 20 раз, а у женщин - в 13 раз. По уровню смертности от болезней, связанных с образом жизни, республика занимала 7-е место в Российской Федерации. Индикаторы смертности от неестественных и насильственных классов причин смерти превысили пороговые, предельно-критические значения.

В пространственном аспекте значимой тенденцией смертности был (и остается на рубеже 20-х гг. XXI в.) более высокий уровень смертности по всем основным классам причин сельского населения, по сравнению с городским. В 1995 г. этот разрыв составил 21 \% (по России - 17 \%). В возрастном аспекте самый высокий прирост смертности был отмечен у населения трудоспособного возраста. С 1990 по 1995 г. коэффициент смертности этой возрастной группы повысился на 80,6 \%, моложе трудоспособного - на 19,4 \%, старше трудоспособного - на 24,4 \%. Из всех возрастных категорий более значительно (на 75 \%) с 1991 по 1995 г. возросла смертность в группе 40-49 лет. В 1995 г. доля населения трудоспособного возраста в общем числе умерших составила 45 \%. Как известно, увеличение смертности взрослых, кроме других негативных последствий, значительно усиливает риск значительного снижения уровня жизни детей или их сиротство.

Среди гендерных особенностей смертности отмечалась тенденция увеличения разрыва в уровне смертности мужчин и женщин. Так, в 1995 г. уровень смертности «сильной половины» населения был на $41 \%$ выше, чем «слабой» (в 1991 г. - на 26 \%). При этом смертность трудоспособных в возрастном отношении мужчин более чем в 4,5 раза превышала смертность женщин. В целом же, за 1991-1995 гг. численность умерших мужчин возросла на 66 \%, женщин - на 43 \%. Высокий уровень смертности существенно сократил и снизил качество человеческого потенциала, с которым республика должна была выйти к рубежу XXI в.

Как известно, важнейшим индикатором состояния популяционного здоровья в целом, здоровья женщин и уровня развития здравоохранения, является младенческая смертность. Коэффициент младенческой смертности увеличился с 16,4 умерших младенцев на 1000 родившихся в 1991 г. до 25,3 в 1995 г. Подобный уровень был зафиксирован в республике в 1980 г. В 1990-е гг. отмечалась тенденция превышения темпов роста младенческой смертности над рождаемостью. С 1991 по 1995 г. уровень рождаемости, как мы уже отмечали выше, снизился на 25 \%, а коэффициент младенческой смертности возрос на 55 \%. Одной из опасных тенденций являлось увеличение в структуре младенческой смертности числа смертей от врожденных аномалий. Возросли фетоинфантильные потери.

В пространственном аспекте в исследуемый период увеличение числа умерших и повышение уровня смертности произошло во всех городах и районах республики. Наиболее значительно возрастание смертности населения было характерно для Воркуты, Вуктыла, Троицко-Печорского района (в два раза). По уровню смертности в 1995 г. среди городов «лидировали» Сосногорск (14 умерших на 1000 населения), Ухта (13,7), Сыктывкар $(13,2)$, среди районов - Корткеросский $(16,3)$, Троицко-Печорский $(16,2)$, Княжпогосский $(16,0)$. В целом социодинамика смертности показывает, что если за точку отсчета принять число умерших в 1990 г., то в последующие годы дополнительные потери («избыточная смертность») составили 20,2 тыс. чел., из них $17,8(88 \%)$ - за три года $(1993,1994,1995)$.

Динамика и тенденции смертности свидетельствовали о значительном ухудшении здоровья населения. В республике с 1991 по 1995 г. общая первичная зарегистрированная заболеваемость населения увеличилась на 25 \%, в том числе взрослого населения - на 29,5 \%, подростков - на 66 \%, детей - на 17 \%. При этом уровень заболеваемости возрос на 31 \%. Наиболее значительно у взрослых (в два раза), у подростков (в три раза) увеличилась первичная заболеваемость инфекционными и паразитарными заболеваниями, эндокринной системы, расстройства питания, нарушение обмена веществ и иммунитета (соответственно на $72 \%$ и в 2.7 раза), болезней нервной системы и органов чувств, у детей врожденные аномалии (в 3,3 раза), болезни органов пищеварения (в 2,2 раза), новообразования (на $93 \%$ ).

В регионе произошла «беспрецедентная реставрация традиционной патологии заболеваемости и смертности». Угрожающей медико-социальной проблемой в республике был рост с 1991 по 1995 г. социально обусловленных заболеваний: сифилиса (в 23 раза), чесотки (в 7,2 раза), впервые выявленного туберкулеза (в 1,8 раза), в том числе, детей до 14 лет (в 3,2 раза). В республику возвратилось такое особо опасное инфекционное заболевание как дифтерия. Заболеваемость дифтерией в 1990-е гг. возросла в 64 раза (с 16 до 1026 случаев).

В 1992 г. была отменена госмонополия на производство и оборот винно-водочных изделий; цена на спиртное была ниже, чем в 1985 г. В 1990-1995 гг. уровень смертности от алкогольных отравлений возрос более чем в шесть раз. Особенно значительно в 1991-1995 гг. возросла заболеваемость алкогольными психозами, являющимися наиболее тяжелым проявлением алкоголизма. С 1991 по 1995 г. число больных алкогольными психозами, взятых под диспансерное наблюдение с впервые установленным диагнозом, увеличилась 
в три раза, а число больных, состоящих под наблюдением с данным диагнозом, в 4,2 раза. По численности больных алкоголизмом и алкогольными психозами с впервые установленным диагнозом республика в 1994 г. занимала в рейтинге российских регионов 9-е место. Смерть 30 \% мужчин и 15 \% женщин была прямо или косвенно связана со злоупотреблением алкоголем.

Состояние здоровья и уровень смертности населения адекватно проявляются в показателе ожидаемой продолжительности жизни. Этот интегральный индикатор уровня и качества жизни населения сократился с 1990 по 1994 г. на семь лет и составил у мужчин 55,2, женщин - 68,4 лет. За эти годы увеличился разрыв в ожидаемой продолжительности жизни мужчин и женщин. Если в 1990 г. этот разрыв составлял у городского населения 10 лет, то в 1994 г. - 13 лет, у сельского населения - соответственно 11 и 14 лет. Подобной дифференциации в продолжительности жизни «сильной» и «слабой» половины не отмечается в странах Западной и Восточной Европы.

Тревожной тенденцией является значительное снижение (на восемь лет) ожидаемой продолжительности жизни мужского сельского населения. Продолжительность жизни среднего сельского мужчины составляла в 1994 г. 54 года. Распределение городов и районов по ожидаемой продолжительности жизни при рождении показывает, что наиболее низкие значения этого важнейшего показателя отмечались в 1994 г. в Сосногорске $(55,6)$, Печоре $(59,5)$, в Воркуте $(60,9)$, среди районов - в Удорском $(56,7)$, Усть-Куломском $(57,1)$, Прилузском (58,5). С 1992 по 1994 г. наиболее значительно (на 9-10 лет) сократилась продолжительность жизни населения в Вуктыле, Удорском и Корткерсском районах, на восемь лет - в Ижемском и Усть-Куломском районах. По этому обобщающему показателю уровня и качества жизни, «качества качеств» республика в 1994 г. занимала 79-е место и находилась в числе 10 регионов России с наиболее низкой продолжительностью жизни.

Одной из форм антропологического кризиса периода 1990-х гг. был духовно-нравственный кризис. Анализ статистических индикаторов девиантного поведения, представленных в статистическом сборнике «Республика Коми в человеческом измерении» [2], позволяет сделать вывод, что основной статистически измеряемой тенденцией, характеризующей процессы духовного неблагополучия, «духовной аномалии», был интенсивный, превышающий предельно-критические параметры духовной безопасности рост абсолютных и относительных показателей девиантного поведения населения, социальных аномалий: превышение темпов роста числа лиц, совершивших преступления, над темпами роста численности населения; усиление криминализации регионального социума, повышение уровня и темпов роста преступности, особенно насильственной; резкое повышение суицидальной активности населения и целый ряд других негативных антропофеноменов.

Как известно, важным индикатором, характеризующим духовно-нравственное состояние общества, является уровень преступности. В 1990-е гг. произошло значительное усиление криминальной активности населения. Так, с 1990 по 1995 г. коэффициент криминализации повысился на 58,5 \% при снижении численности населения республики на 6,3 \%. С 1990 по 1995 г. число лиц, нарушивших уголовный кодекс, возросло в 1,5 раза. Преступления совершили более 57 тыс. чел. (свыше 90 \% из них - жители республики). Среди возрастных групп наивысшая криминальная активность зафиксирована у подростков в возрасте 16-17 лет (коэффициент 3,1 ) и молодежи в возрасте 18-24 года (коэффициент 2,1). О повышенной криминальной агрессивной активности подростков и молодежи свидетельствует и тот факт, что их доля в составе лиц, преступивших закон, соответственно в 2-2,5 раза превышает удельный вес этих категорий в структуре народонаселения. Это позволяет сделать вывод о чрезвычайно опасной тенденции омоложения криминального сообщества, что потенциально способствует «расширенному воспроизводству преступности.

Среди социальных групп населения самые высокие показатели криминальной девиации были зарегистрированы у таких маргинальных групп, как безработные, у лиц, не имеющих постоянного источника дохода и места жительства. В 1990-е гг. их криминальная активность значительно возросла. Так, если с 1993 по 1995 г. число лиц, нарушивших уголовный кодеке возросло на 22\%, то число безработных, совершивших преступления, увеличилось в 2,9 раза, не имеющих постоянного места жительства - в два раза, не имеющих постоянного источника дохода - в 1,7 раза. Данные категории населения составляли 76 \% членов преступного сообщества, совершивших тяжкие преступления (хотя удельный вес этого контингента в составе преступников составлял $46 \%$ ).

Тревожной тенденцией исследуемого периода в сфере криминализации являлось увеличение числа женщин, совершивших преступления, и повышение их удельного веса в составе лип, преступивших закон с $9 \%$ в 1992 г. до 12 \% в 1995 г. Одной из самых опасных тенденций в криминальном поведении населения 1990-х гг. являлось повышение уровня и увеличения числа насильственных преступлений, что свидетельствовало об усилении жестокости и агрессивности в обществе. Темпы прироста умышленных убийств, тяжких телесных повреждений существенно опережали рост общей преступности. Так, за период 1991-1995 гг. при росте общей зарегистрированной преступности на 12,5 \%, число убийств (с покушениями) возросло на 86,4 \%, тяжких телесных повреждений - на $42 \%$. 
Коэффициент убийств (число убийств на 100000 населения), являющийся, по мнению криминологов, наименее латентным, а потому и наиболее объективным индикатором криминогенной ситуации н криминогенных процессов, превышал аналогичные показатели Российской Федерации в 1,5 раза, США - в 3,3 раза, Финляндии - в 10 раз, Швеции - в 22 раза, Норвегии - в 33 раза. По сравнению с западноевропейскими странами смертность от убийств в России была выше у мужчин в 20 раз, а у женщин - в 13 раз. Анализ региональных характеристик криминализации населения в исследуемый период свидетельствовал о том, что наиболее высокий уровень криминальной активности населения отмечался в 1995 г. в Печоре, Вуктыле, Сосногорске, в Корткеросском, Княжпогостском, Сыктывдпнском районах, убийств - в Вуктыле, Ухте, Воркуте, Прилузском, Троицко-Печорском. Княжлогостском районах.

Показателем духовного и душевного неблагополучия служит уровень самоубийств, являющийся высокочувствительным и точным индикатором социопсихологической дезадаптации населения, сложнейшим, многофакторным антропо-социо-психо-экзистенциальном явлением, «неизъяснимым феноменом в нравственном мире» (Н. Карамзин), «великой печалью русской жизни» (И. Павлов). Основной социодинамической характеристикой самоубийств в республике (как н в целом в России) в исследуемый период являлось значительное увеличение темпов их прироста, количества и повышение уровня. С 1990 по |1995 г. коэффициент самоубийств (число умерших от самоубийств на 100 тыс. населения) возрос с 30.8 до 55,8 (в 1,8 раза). За этот период «добровольно ушли от действительности» 3380 чел. (целый населенный пункт). В 1995 г. от суицидов погибло в семь раз больше, чем умерло от болезней эндокринной системы, нарушения обмена веществ, в три раза больше, чем от хронического алкоголизма, н 4,3 раза больше, чем от психических расстройств, и 1.5 раза больше, чем от инфарктов.

О повышении уровня суицидальности населения, усилении депрессивных настроений свидетельствовала тенденция превышения темпов роста самоубийств по сравнению с темпами прироста населения. С 1990 по I995 г. число самоубийств возросло на 71 \%, а среднегодовая численность населения сократилась на 5,6 \%. Анализ самоубийств по месту жительства суициндентов выявил характерную как для Республики Коми, так и для России в целом тенденцию более высокого уровня суицидов сельского населения по сравнению с городским. Разрыв в уровнях самоубийств горожан и «селян» увеличился с 37 \% в 1990 г. до 64 \% в 1995 г., что свидетельствовало о нарастании депрессивных настроений сельского населения, повышении уровня социопсихологической дезадаптации жителей сельских районов.

Распределение городов и районов по уровню самоубийств показывает, что в 1995 г. наиболее высокий коэффициент суицидальной активности среди городского населения отмечался в Ухте, Сосногорске, Усинске, среди районов - в Ижемском, Сысольском и Прилузском. Самое высокое значение индекса суицидальной активности населения в 1990-е гг. (и в настоящее время) отмечалось в Ижемском районе. Уровень самоубийств в этом муниципальном образовании в 2-2.5 раза выше среднереспубликанских показателей. Эта же суицидальная ситуация сохраняется и по данным за 2019 г. Причинный комплекс высокого уровня суицидов в этом районе (как и в республике в целом) требует специального системного суицидологического исследования с участием суицидологов, психологов, социологов, демографов, этнографов, физиологов и других экспертов.

Устойчивой общемировой тенденцией суицидального поведения населения является более высокий уровень самоубийств мужчин по сравнению с женщинами. В 1995 г. это превышение составило 5,4 раза (в 1990 - 3,9). В республике (как и в России) этот разрыв в 2-2,5 раза выше, чем во многих западных странах. «Сверхсуицидальность мужчин» объясняется в суицидологии природным, более низким по сравнению с женщинами, порогом биосоциальной адаптации и более высоким уровнем алкоголизации «сильной половины». Наиболее суицидоопасный возраст мужчин отмечается в возрастной когорте от 35 до 49 лет. В сельской местности - от 25 до 39 лет, у женщин - от 70 лет н старше,

Несмотря на некоторое снижение суицидальной активности населения в 1995 г., ее уровень оставался высоким, в 2-2,5 раза превышающим пороговое значение, определенное Всемирной организацией здравоохранения. Более подробно о проблемах и флуктуациях суицидального поведения населения республики говорилось в ряде наших публикаций [3; 4].

Причинный комплекс антропологического кризиса начального периода социетальной трансформации имеет многофакторные основания (от общефедеральных, до специфически региональных, от социо-экономических до духовно-экзистенциональных, социопсихологических). Учитывая формат статьи, отметим на некоторые из них. Безусловно, общей, сущностной причиной общефедерального уровня является радикальная, ревореформенная, «социетальная трансформация» (Т.И. Заславская), крупномасштабный трансформационный исторический процесс, захвативший основы бытия человека и всего общества, затронувший все сферы жизнедеятельности российского социума: социальную, экономическую, политическую, социокультурную, духовную и все уровни общественной вертикали - общенациональный, региональный, локальный, групповой и индивидуальный, все базовые общественные институты. 
Каузальные основания флуктуации резкого негативного изменения антропотенденции с относительно стабильных после 1992 г. могут быть объяснены концепцией Дюркгейма - Сорокина, согласно которой во время экономических кризисов, бедствий, психологического «голода» происходят разрывы социальных связей, что стимулирует ментальную дезинтеграцию и дезорганизацию. Это «социотрясение» (Б. Грушин), депрессия общероссийского масштаба способствовала усилению маргинализации населения. Высокий уровень социальной дезадаптации, аномии в сложных условиях начального этапа трансформации оказал негативное влияние на психическое состояние и здоровье людей. Для большинства населения это был период тяжелейших экзистенциальных, психоэмоциальных испытаний. Населению была нанесена тяжелейшая биопсихологическая и «социокультурная травма» (П. Штомпка), что способствовало усилению антропологического кризиса.

Негативное социальное самочувствие сформировало психологическую напряженность значительного регионального социума, что, согласно закону «духовно-демографической детерминации» (И. Гундаров), в свою очередь, оказало влияние на повышение уровня заболеваемости, смертности, рост преступности, снижение рождаемости, увеличение разводов и т д. Сбой в психической сфере потянул за собой возникновение психосоматических расстройств, существенно повысив восприимчивость (как мы уже отмечали выше), к социально значимым заболеваниям, росту смертности от самоубийств и другим внешним причинам смертности.

Наиболее существенными формами проявления кризисных процессов в социально-экономической сфере Республики Коми в начальный период социетальной трансформации являлись: сокращение почти в два раза промышленного производства; рост инфляции в 35 раз; снижение в 2-3 раза реальных денежных доходов. Кроме того, в республике в те годы впервые появилась безработица, и ее уровень возрос с 1,3 в 1991 г. до 6 \% в 1995 г. В регионе почти в два раза снизился розничный товарооборот, но при этом одновременно в два раза увеличилось потребление спиртного (в том числе суррогатного спирта «Рояль»- аналога «Трои»).

В республике резко усилились социальная дифференциация, глубина и острота бедности населения. Важнейший показатель, характеризующий уровень бедности - численность населения с денежными доходами ниже прожиточного минимума возросла до 30 \% в 1995 г. Изменился социальный состав низкодоходных групп. Если в дореформенный период малообеспеченными были в основном семьи неработающих пенсионеров, инвалидов, неполные и многодетные семьи, то период «шоковой терапии» к ним присоединились новые категории экономически активного населения. В 1991-1995 гг. снизилось потребление почти всех видов продуктов питания. Расходы на питание 10 \% наименее обеспеченного населения были в три раза меньше, чем у такой же доли наиболее обеспеченных, на непродовольственные товары - в 15 раз, оплату личных услуг в девять раз. Согласно расчетам Л.А. Поповой, «социальными последствиями экономических преобразований в Республике Коми обусловлена значительнейшая часть - более $60 \%$ - снижения уровня рождаемости в 90-е гг. и более 90 \% роста уровня смертности в первой половине 90-х годов» [1, с. 109].

За сравнительно короткий период (4-5лет) кардинально изменилась экономическая, политическая, идеологическая, духовная подсистемы общественной жизни регионального социума. Законодательно это было закреплено в принципиальной новой «по букве и духу» Конституции Республики Коми, принятой 17 февраля 1994 г. Верховным Советом республики. Анализируя процессы формирования регионального конституционализма и характер принятия Конституции 1994 г., правовед О.В. Головина справедливо отмечает, что «в региональном конституционно-правовом пространстве и времени, в политической системе региона состоялась революционная конституционная реформа как форма разрешения конституционного кризиса» [5, с. 123].

Как нам представляется, на основе изучения и анализа исторического опыта деятельности по смягчению последствий антропокризиса, анализа современных антропотенденций органам государственной власти необходимо обеспечить проектирование, принятие и реализацию концепции и стратегии социогуманитарного преображения Республики Коми, практическую реализацию гуманитарных национальных проектов и основоположений обновленной Конституции Российской Федерации и Конституции Республики Коми о человеке, как высшей ценности и о создании условий для развития человеческого потенциала в регионе.

\section{Источники и литература}

1. Попова Л.А. Сущность, причины и последствия современного демографического кризиса (на примере Республики Коми). Екатеринбург: УрО РАН, 2004.

2. Республика Коми в человеческом измерении. Статистический сборник. Сыктывкар: Госкомстат Республики Коми, 1996.

3. Теребихин B.M. К вопросу о валидности и актуальности использования идей Питирима Сорокина о самоубийстве для анализа суицидального поведения населения Республики Коми в конце ХХ - первом десятилетии XXI века // Историческая демография. 2019. № 1. С. 47-51. 
4. Теребихин B.M. Флуктуации суицидального поведения населения Республики Коми // Социологические исследования. 2012. № 10. С. 48-55.

5. Головина О.В. Принятие Конституции Республики Коми 1994 года как конституционная революционная реформа и форма разрешения конституционного кризиса (к 95-летию образования Коми автономии) // Третьи юридические чтения: Всероссийская научно-практическая конференция, г. Сыктывкар, 26-27 ноября 2015 г. Сыктывкар: Изд-во СГУ им. Питирима Сорокина, 2016. Ч. I. 128 с. 


\title{
НАУЧНОЕ НАСЛЕДИЕ
}

УДК 001.891.55:39(470.13-13)(047.3)

\author{
Л.П. Лашук, Л.Н. Жеребиов*
}

\section{Отчет Прилузской этнографической экспедиции 1959 г. Материалы к этнической истории**}

\author{
Введение.
}

В 1959 г. Коми филиалом АН СССР была организована этнографическая экспедиция в Прилузский и Летский районы Коми АССР [в настоящее время территория бывшего Летского р-на является частью Прилузского р-на Республики Коми]. Члены экспедиции - старший научный сотрудник Л.П. Лашук (руководитель) и младший научный сотрудник Л.Н. Жеребцов - в течение двух месяцев (июнь-июль) работали вначале на Летке, в райцентре и в сельсоветах Слудском, Гурьевском, Мутницком, затем в Прилузье, в райцентре Объячево и в сельсоветах Ношульском, Читаевском, Лоемском, Спаспорубском и Занульском. Всего обследовано 11 селений и 4 рабочих поселка.

Особенностью экспедиции текущего года являлось то, что она была завершающей по сплошному этнографическому обследованию Коми АССР, начатому нами в 1951 г. Так как Прилузье в прошлом не подвергалось этнографическому изучению, то в результате работ текущего года ликвидировано еще одно «белое пятно» в этнографии Коми АССР и создалась возможность иметь полное представление о всей территории республики.

Изучение этнографии Прилузья и Летки имеет свой особый интерес, так как эта южная часть Коми АССР заметно отличается от других районов коми целым рядом существенных черт - диалектными различиями, спецификой исторического развития, хозяйства, материальной культуры и быта. Прилузье и Летка имеют некоторые различия между собой, но в целом, по главным этнографическим показателям, это единый хозяйственно-культурный район, которому мы присвоили наименование Прилузского этнографического района.

Полевые работы производились по ранее разработанной программе, составленной на основании принципов советской этнографической науки и конкретного опыта экспедиционных исследований прошлых лет в условиях Коми АССР. Программа предусматривала сбор всего доступного материала по таким важнейшим разделам как

1) вопросы этнической истории, современный этнический состав и этнические взаимоотношения населения Прилузья и Летки;

2) специфические особенности хозяйства прилузско-летских коми в прошлом и на современном этапе;

3) материальная культура и быт;

4) духовная культура - устное поэтическое творчество, верования, поверье и т.д.

Перед нами стояла задача выявления не только этнографической «живой старины», но и, главным образом, изучение того этнографического уклада, который существует в настоящее время и в котором сложно переплетаются новые культурно-бытовые явления с традиционными формами и обычаями прошлого. Как по-

\footnotetext{
* Лашук Лев Павлович (1925-1990) - доктор исторических наук, профессор Московского государственного университета. В 1950-1960 гг. работал в Коми филиале АН СССР. Жеребцов Любомир Николаевич (1925-1991) - кандидат исторических наук, заведующий сектором этнографии Института языка, литературы и истории Коми филиала АН СССР.

** Фрагмент научного отчета, подготовленного в 1960 г. и хранящегося в Научном архиве Коми научного центра УрО РАН (Ф. 1, оп. 13, д. 48. 151 мпс.). Отчет был обсужден и принят производственным заседанием отдела истории, этнографии и археологии 25 мая 1960 г. К отчету прилагались три альбома и одна папка с иллюстрациями (241 иллюстрация). Публикуемый фрагмент текста находится на листах 3-47 и подготовлен к публикации сотрудниками ИЯЛИ ФИЦ Коми НЦ УрО РАН д.и.н. И.Л. Жеребцовым и Л.Я. Каневой. В квадратных скобках даны необходимые пояснения и примечания публикаторов. Нумерация сносок при публикации изменена с постраничной на сквозную.
} 
казала практика полевых работ, Прилузье и Летка в этом отношении дают обильный и интересный материал, в частности, сочетание весьма архаических элементов с новинками современной культуры.

Наконец, в полевых условиях, так сказать, на месте, мы стремились проверить и уточнить разработанный ранее метод определения этнографических районов и микрорайонов в пределах больших культурно-исторических областей. Опыт Прилузья показал, что в принципе этот метод правильный, но нуждается в поправках, например, в том, что каждый этнографический район при всех общих закономерностях районирования определяется в зависимости от специфических условий не только этнического, но и исторического развития района.

Попутно с этнографическими исследованиями нами производилась также археологическая разведка, которая не дала никаких результатов на Летке, где ни один из многих опрошенных старожилов никогда не слыхал о «чудских» древностях, т.е. находках древних вещей, но оказалась успешной в Прилузье, где обследованы три осадных городка XV-XVI вв. и древний могильник с трупосожжениями.

Ниже излагаются систематизированные полевые материалы с основными выводами из них, подкрепленными там, где это было необходимо, ссылками на литературные и архивные источники, археологические и языковые данные.

\section{1. Материалы к этнической истории.}

Приступая к изучению Прилузского этнографического района, мы поставили перед собой ряд наиболее важных вопросов этнической истории этого края, которые не получили еще достаточного освещения в специальной литературе. Материалы экспедиции 1959 г. в сочетании с показаниями иных источников позволяют выдвинуть некоторые новые соображения по этногенезу прилузско-летского населения.

Первый вопрос, интересующий нас, касается времени появления в Прилузье его старожильческого населения - коми и русских.

В настоящее время это население размещено компактно и имеет четко выраженные этнические границы. В Прилузском районе коми проживают по всей верхней Лузе и вдоль тракта Ношуль - Летка, за исключением Лоемского сельсовета, заселенного сплошь русскими - старожилами. Смешанным (коми и русскими) составом отличается Спаспорубский сельсовет, по территории которого как раз и проходит этническая граница, установившаяся настолько давно, что даже в самых старых преданиях не фиксируется какое-либо иное положение. В Летском районе все старожильческое население считается коми, за исключением русских жителей д. Бебера Летского с/с [сельсовета], поэтому этническим рубежом между коми и русскими здесь правильно считать линию, в основном совпадающую с административной границей между Коми и Кировской областью.

Местная устная традиция одинаково считает здешних коми и русских старожилами, но, с одной стороны, называет их предшественниками легендарную чудь, а с другой, подчеркивает, что поскольку на территории Лоемского с/с встречаются урочища с коми названиями, то русские жители здесь появились все-таки позднее, нежели коми. К этим преданиям мы еще вернемся ниже, а теперь изложим некоторые соображения относительно этногенеза прилузских коми.

Самое раннее письменное свидетельство о них датируется 1485 г. [1]. В жалованной грамоте этого времени, данный Иваном III «волостным людям пермякам» (в данном случае коми-зырянам»), упомянуты жители «Лусские Пермцы» - большой средневековой волости, охватывавшей р. Лузу с верховьев до впадения p. Лехты [2]. Не подлежит сомнению, что здесь речь идет именно о коми-зырянском населении Прилузья. Вопервых, само название волости - «Пермца» - указывает на этническую общность ее обитателей с Прикамской «Пермью Великой» (коми-пермяки) и с Вычегодской Пермью (коми-зырянами); во-вторых, прилузские коми до недавнего времени называли себя «пермяками», а их русские соседи не признавали такого самоназвания; в-третьих, имеется прямое свидетельство 1676 г. о том, что «Лузская Пермца местечко бедное самое худое, а людишка зыряне безответные» [3].

Последнее указание важно и тем, что подчеркивает принадлежность прилузских коми к зырянам Вычегодского края, а не к верхнекамским пермякам. Нисколько не противоречат этому и данные языка: говоры Прилузья и Летки основными своими особенностями всецело примыкают к коми-зырянским (преимущественно сысольским) говорам, хотя и обладают некоторыми специфическими чертами, сближающими их и с северными коми-пермяцкими говорами [4].

Но откуда и когда предки появились в Прилузье? Точного ответа мы пока еще не можем дать, но многое говорит за то, что пришли они со средней Сысолы гораздо раньше XV в. С сысоличами - наиболее ранними потомками древних пермских переселенцев с Верхокамья [5] - прилузские коми имеют наибольшую близость не только в языке, но и в антропологическом типе [6], да и наиболее вероятный путь их миграции мог лежать только со средней Сысолы по р. Визинге и через Кибринский волок, нежели из какого-нибудь другого района древнего расселения коми. 
Предки лузян отделились от сысоличей сравнительно рано. В их говоре сохранилось немало общепермских элементов, давно уже исчезнувших в вычегодских говорах, также развивавшихся на основе сысольского «элового» диалекта. Да и на самой Сысоле эти языковые явления сохранились только в глухих местах - в Ужге и на р. Кобре [7]. В прилузском говоре отмечены отдельные вепсские заимствования (типа «пу агас» - деревянная борона), отсутствующие в сысольском и многих других говорах коми языка, что является свидетельством древнего контакта лузян с вепсами, обитавшими в бассейне Северной Двины и ее верхних притоков (Сухоны, может быть, Юга) еще до появления русских, т.е. до XI-XII вв. Подобный контакт не мог иметь места позднее, ибо с XII на устье Юга прочно обосновались «низовские» (ростово-суздальские) русские, в XIII-XIV вв. колонизовавшие поюжские и нижнелузские земли. Значит, на Лузе коми появились гораздо раньше русских, видимо, еще до XI-XII вв.

До недавнего времени на сенокосе лузяне сооружали жилище особого типа - «колу», представлявшую собой низкий бревенчатый сруб (в несколько венцов), покрытый двускатной крышей из корья. Внутри в длинной яме устраивался очаг, по обеим сторонам которого располагались земляные скамьи для спанья (см. подр. описание ниже). Любопытно, что Прилузская «кола» до мельчайших деталей близка «родановскому» дому прикамских поселений IX-XII вв. [8]. Остатки такого же дома обнаружены А.П. Смирновым на вычегодском городище Кармыльк XV-XVI вв. [9]. В поселениях XII-XIV вв. родановский дом сменяется примитивной срубной избой «вӧр керка» [10]. В Спаспорубском осадном городке XV-XVI вв. нами вскрыто именно такое жилое сооружение (см. ниже). Из всего этого напрашивается вывод: в Прилузье коми пришли тогда, когда у них еще бытовало жилище наподобие родановского дома, возникшего у пермских племен еще в ломоватовское время, т.е. до IX в.

Интересный материал дает древний могильник, разведанный нами в с. Лойма. Так как это, по сути дела, первая достоверная находка древних захоронений в Прилузье, остановимся на ней подробней. В 1958 г. в результате выемки песчаного грунта из склона последней надпойменной террасы, на которой расположена центральная часть Лоемского c/c - Погост, а ниже к реке за неширокой заболоченной полосой находится «городище» (остатки осадного Лоемского городка XV-XVI вв., рабочими случайно были найдены человеческие кости, которые старожилами сразу же были приписаны чуди, живьем закопавшей себя в землю. Что это были за кости, нам установить, к сожалению, не удалось.

При обследовании места находки обнаружилось следующее. Уступ террасы - невысокий (до 5 м), пологий, сложенный из материкового песка оранжевого оттенка. Судя по истлевшим остаткам пней в слое, некогда на террасе произрастал сосновый бор, но он давным-давно сведен, а полоса от края террасы до первых домов, шириною метров в 200, распахана. Никто не помнит, чтобы у края террасы когда-либо были постройки или кладбище, да и сам характер захоронений не на ровной площадке, а в откосе без всяких надмогильных насыпей, указывает на древний характер могильника. Откос сильно разрушен земляными работами, в результате чего образовалась глубокая выемка, шириною не менее 20 м. На оранжевом фоне материкового песка в осыпи на расстоянии всего в 6-8 м и на глубине 80-100 см от верхнего задернованного края ясно выделялись три впускных пятна серого цвета с многочисленными углистыми вкраплениями и углистой прослойкой в нижнем горизонте толщиною в 40-50 см, выше которой шел обычный песок.

Особенно интересно одна линза шириной всего в 60-70 см, представляющая собой как бы нишу в обрыве, заполненную углисто-серой прослойкой и некрупными камнями. Расчистив эту линзу вглубь берега на 20-30 см. мы встретили человеческий череп, лежащий явно in sity на затылке, лицом кверху, ориентированный теменем на Север (или точнее, на северо-северо-запад), т.е. в сторону противоположную реке. Под затылком черепа слева и справа подложены мелкие камни. Сразу же за черепом характерный серый слой обрывался и далее вглубь шел тот же материковый песок (альбом, снимки 2, 3) [фотографии не публикуются]. Череп небольшой, частично разрушенный: совершенно отсутствуют правые половины верхней и нижней челюсти, в куполе черепного свода неровное отверстие - не известно, исскуственного или естественного происхождения. Однако череп вполне пригоден для некоторых важнейших краниологических измерений, что и было нами произведено.

Доступные измерению размеры.

\begin{tabular}{|l|l|}
\hline окружность черепа & около 500 мм \\
\hline продольный диаметр & 175 мм \\
\hline поперечный диаметр & 132 мм \\
\hline скуловой диаметр & 112 мм \\
\hline ширина орбиты & 42 мм \\
\hline черепной указатель & 75,4 \\
\hline
\end{tabular}


Единичность объекта и невозможность всех измерений по принятой краниологической программе исключает сколько-нибудь определенные выводы относительно этнической принадлежности лоемского черепа, но суммарно он примыкает к группе женских черепов из известного Поломского могильника IX в. (Удмуртская АССР), о которых Г.Ф. Дебец писал: «Поломская серия представляет собой смешанное население, составные компоненты которого (протоевропейский и умеренно монголоидный. - Л.Л.) можно было проследить в ранних могильниках ананьинского типа, но которые к этому времени (IX в. н.э.) слились так, что выделение типов, что выделение типов стало невозможным, по крайней мере на небольшом материале» [11].

Таким образом, в указанном месте мы столкнулись с захоронением, которое, судя по наличию в обнажении по крайней мере трех могильных пятен и прежним костным находкам, сделанным населением, было здесь не единственным. По всей вероятности, возле Лоймы существовал древний могильник со своеобразным обрядом захоронения. Какие-либо вещи или иные костные остатки нами после тщательных двухдневных поисков не обнаружены. Сам же обряд захоронения рисуется в следующих чертах: древние лоймичи практиковали не трупоположение, а трупосожжение своих покойников; остатки погребального костра в виде золы, углей, перегоревших косточек ссыпали в неглубокую грунтовую яму, сюда же иногда клали отдельно череп, может быть, вещи.

Могилы имели ориентировку на Север или Северо-Запад, располагались друг подле друга рядами, не имели надмогильной насыпи. Подобный обряд известен на Вычегде в могильниках XI-XII вв. Вот что, например, пишет о могильнике Дзиб-яг А. Грен: «Поверхность Дзиб-яг была сплошь с углублениями или так наз. чудскими ямами... Кремация эта, впрочем, была частичной, т.к. в четырех из открытых нами могил было положено по черепу, а в десяти положении большие и малые берцовые кости. Могил 15 было таких, где не было ничего, кроме пепла. Черепа лежали все, стоя лицом к северу, затылочным отверстием вниз... Кости ног почти всегда находились среди могил по направлению с юга на север, череп лежит по большой части в северозападном углу» [13].

По аналогии в обряде захоронения Лоемский могильник, видимо, должен быть поставлен в один ряд с таким же памятниками Вычегодского края рубежа I и II тыс.н.э. и приписан предкам коми. Поскольку здесь очевидна вероятность обнаружения других захоронений как по неразрушенному земляными работами склону террасы, так и на самой террасе, поскольку резонно произвести дальнейшие раскопки Лоемского могильника.

В общем, полевые археологические и этнографические материалы 1959 г. в сочетании с данными других дисциплин позволяют уточнить время появления коми в Верхолузье. Их поселения в этом районе существовали в XI-XII вв., но возникли, вероятно, еще раньше - по крайней мере, в конце I тыс. н.э.

В более определенных чертах рисуются также крайние западные пределы расселения коми по р. Лузе. Район Лоймы, с давних пор заселенный русскими, первоначально был занят предками современных прилузских коми. На это указывают материалы Лоемского могильника (русским не был свойственен описанный выше обряд захоронения) и данные топонимики. Само население указывает, что многие речки, ручьи и урочища, пожни в Лоемском с/с носят коми названия: Зудшор - брусчатый ручей, Валог - мокрый лог и т. д. На современных картах по р. Лузе от впадения Лёхты указаны притоки Вонил, Ягил, Кычавож, по р. Лёхте - Сорваж, Дингель, Сотчемъель, Изагель. Коми-зырянская топонимика перекрывает территорию старой Лузской Пермцы, которая некогда была целиком занята коми, но затем частично заселена и русскими.

К сожалению, нам не удалось записывать предания, которые бы приурочивали появление русских к какойлибо определенной эпохе. Обращает на себя внимание заметное различие местных и вычегодских легенд о чуди. На Вычегде исчезновение чуди обычно связывается с миссионерской деятельностью Стефана Пермского, т.е. фактически с русским проникновением. В Прилузье какое-либо представление о Стефане Пермском отсутствует, а чудь, хотя и здесь, также как на Вычегде и Сысоле, «уходит в землю», но вне всякой связи с христианизацией или появлением русских. В Лойме рассказывают, что чудские люди зарывались в ямки только тогда, когда приходило время умирать. В Читаево причиной самозахоронения чуди считается нежелание ее подчиняться чужому владычеству, но чьему - не известно.

Суммируя эти легенды, мы приходим к выводу: 1) деятельность Стефана Пермского на Прилузье не распространялась; 2) христианизация прилузских коми происходила в иной обстановке, нежели на Вычегде, и, видимо, очень давно и постепенно, как бы незаметно, ибо явно не носило характера единовременного акта, а поэтому не оставило памяти в качестве яркого переломного события; 3) не исключено, что христианами лузяне стали раньше, чем вычегодские и вымские коми, так как, во-первых, Прилузье с XII-XIII вв. входило в орбиту сильного влияния Великого Устюга, а во-вторых, в связи с этим Стефану проще было бы направиться на Лузу, а не на Вычегду, если бы в его время, т. е. в конце XIV в., Прилузье пребывало еще в «прелести идольстей».

Самые ранние сведения о русском населении Лоймы мы находим в переписных книгах 1625 и 1645 гг. Правда, жители Лоемского погоста и в этих источниках прямо не названы русскими, но названия деревень здесь исключительно русские, топонимика также указана преимущественно русская: Лужок, Малое Лоемское 
озерко, Чертоломский плес, Нижний конец, но выше по Лузе, начиная с устья р. Поруб, характер названий резко меняется: Тыил, Коздин, Салтыил, Ичертыж, Кервавубок, Кузьвад и т.д.

Есть основания думать, что в Лойме русские поселенцы появились много раньше начала XVII в., когда в этом погосте насчитывалось 58 населенных пунктов. Ниже Лоймы, в районе Лальска, русские деревни упоминаются в 1520-х годах, но и они, конечно, возникли не в эти годы, а раньше [13]. Наиболее вероятное время массовой колонизации русскими крестьянами нижнего Прилузья - XIV-XV вв.

Некоторые коренные лоемские фамилии позволяют определить местность, откуда их родоначальники переселились в пределы Лузской Пермцы. Явно топонимический характер носят фамилии Низовцев (т.е. уроженец низовьев какой-то реки, видимо, Лузы или Юга) и Шехонин (т.е. выходец с р. Шехони). Безносиковы имеют однофамильцев на нижней Лузе в Вымске, Бородкины (или Бородкины) - среди устюжан XVII в., Тырышкины - среди вятчан того же времени [14]. Примечательна фамилия Чужмаров, считающаяся коренной русской, но несомненно производная от древнепермского «чужмӧр» («чӧжмер») - горностай. Не исключено, что ее родоначальник был коми, потомство которого обрусело.

Мы не занимались специально изучением лоемского говора, но не могли не заметить, что он не имеет никакой примеси коми-зырянского вокализма, сохранил в массе древнерусскую лексику, легко сопоставимую с языком известных нам документов, и ближе всего стоит к говору устюжан.

В Лойме существуют предания, связанные со здешним «городищем», на котором при распашке находили различные металлические предметы, например, обоюдоострую железную кирку. По словам старожилов, городище это, конечно, «чудское», возле него будто бы происходили сражения. Внешних следов от укрепления ныне не сохранилось, но указывают на широкий и глубокий ров, пересекающий один из высоких мысов боровой терассы, несколько выше которого расположен обследованный нами древний могильник.

Лоемское городище действительно является памятником, но не «чудским», а периода упрочения власти Московского великого князя в северо-восточных землях. В одном ряду с ним стоят «городки» Спаспорубский и Объячевский, о которых также существуют легенды, как о крепостях, защищавших прилузское население от нашествия врагов.

Об этих городках мы собрали все письменные известия, а в период экспедиции произвели на них археологическую разведку. Оказалось, что это наиболее поздние, но весьма интересные памятники феодальной эпохи, времен русской колонизации и важных событий в Прилузье. О здешних городках имеются письменные свидетельства XVI-XVII вв. Так, в «Книге Большому чертежу» сказано: «А по реке по Лузе городки Устюжские же. Городок Объячеи, от Вятки от города от Слободы 50 верст. А ниже Объячево 60 верст, на Лузе, городок Спаскои. Ниже Спаского 20 верст, Лосменои (Лоемский. - Л.Л.). Ниже Лосменого 70 верст, Андреевской Соли Вычегодской» [15]. Мы знаем также, что в XVI в. Объячевский городок был обнесен деревянной стеной с двумя башнями и тайником, выходившим к реке. Но уже к 1625 г. городок пришел в ветхость, а в 1645 г. «того городка нет, только место, и подошвы не знат» [16]. Подобной же была судьба и других городков. В переписной книге 1645 г. Лоемский городок совершенно не упоминается, о Спаспорубском также не сказано ни слова, но на погосте подле былого городка еще имелся «анбар зеленый, а около ево тын стоячей», где хранился «наряд» - огнестрельное оружие и боеприпасы [17], вероятно, перенесенные из разрушенного городка.

Возникает вопрос, когда и в связи с чем были построены упомянутые осадные городки. И.С. Макаров по этому поводу пишет следующее: «B XVI в. крестьянские волости по Лузе подвергались нажиму со стороны «луговой черемисы», периодически опустошавшей русские и коми переселения. Для защиты на Лузе строились городки» [18]. М. Богословский полагал, что осадные городки в землях коми создавались московским правительством в качестве опорных пунктов с русским гарнизоном для упрочения великокняжеской власти среди туземного населения [19]. Наконец, С.В. Бахрушин и А.А. Зимин склоняются к мнению, что многочисленные осадные городки на территории Коми края возникли в XV в. «по инициативе самих жителей, на месте древних городищ, но в их устройстве могло принимать участие и московское правительство» [20].

По нашему мнению, в данном вопросе следует внести некоторые существенные уточнения. Наиболее вероятное время возникновения прилузских, равно как и сысольских, затинных городков - последняя четверть $\mathrm{XV}$ в., т.е. период, когда московское правительстве проводило весьма активную политику на Севере, в Прикамье и Приуралье. Достаточно напомнить, что в это время бывшие новгородские владения на Севере окончательно отходят к Москве, происходит присоединение Перми Великой и прочное включение Вятской земли в состав русского централизованного государства. Поскольку все эти события, сопряженные с военными действиями, протекали в непосредственном соседстве с Коми краем, давно считавшимся «вотчиной» великого князя московского, то территория края играла роль немаловажного плацдарма для наступления и обороны.

$\mathrm{XV}$ в. действительно был весьма беспокойным столетием для населения коми. Двадцатилетняя феодальная война (1432-1453 гг.) Василия II с галицкими князьями Юрием и Дмитрием Шемякой причинила немалые 
бедствия землям коми. Подстрекаемые Шемякой вятчане «приходили есте многажды на великого князя вотчину... Сысолу и Вым и Вычегду», многие села пограбили и пожгли, жителей «перемучили, переморили», а частично забрали в плен [21]. В этом документе - послании митрополита Ионы вятчанам - не упомянуто Прилузье, но несомненно, что вятский разбойный набег коснулся и Прилузья.

В 1459 г. Иван III организовал ответный поход на Вятку [22], но успокоения в напряженную обстановку в этом районе он не внес. В 1462 г. «рать Черемиская с тотары казаньскими приходили на Устюжъскии уезд, на верх Югу реки, на волость на Лоху, повоевали, в полон повели много русских голов» [23]. В 1486 г. «вятчане пришли ратью на Устюг; у города не были зане же весть ушла перед ними. И стояла под Осиновцом городком день и прочь пошли, а 3 волости разграбили, а устюжане в погоню за ними ходили, да не дошли их» [24]. Два года спустя «великого князя воеводы стояли на Устюге, стерегли земли устюжские от вятчан» [25].

В это тревожное, полное военной опасности время устюжане усиленно сооружали крепости - городки Кичменьгу и Осиновец на Юге; в 1478 г. царь Иван III специальным указом «велел ставити город Устюг новои, а старои разваляти». Вероятно, тогда же началось строительство осадных городков на Лузе.

«Книга Большому чертежу» называет прилузские городки «устюжским», что ясно показывает, по чьей инициативе они создавались. Вместе с тем, в сооружении оборонительных объектов было заинтересовано и местное население, которое, по всей видимости, было основной рабочей силой в этом строительстве. Уставная грамота, выданная Лузской Пермце в 1556 г, подчеркивает: «И города Устюга и Соли-Вычегодской и иных городов Луские Пермцы крестьяне не делают, а делают они в Луцкой Пермце свои городки» [26].

Впрочем, в это время необходимость в осадных городках уже отпала. Мятежная Вятка еще в 1489 г. сделалась на милость московскому великому князю [27] и превратилась в одну из мирных провинций русского государства, в конце XV-XVI вв. было нанесено окончательное поражение Казанскому ханству. Заметим кстати, что в начале XVII в. некоторые жители Лузской Пермцы свободно переселялись «в Казанский уезд на Кукарку» [28]. Поэтому у нас есть все основания считать, что основное время существования прилузских затинных городков это - конец XV и весь XVI в. В течение последнего столетия городки, вероятно, подновлялись, но затем были оставлены за ненадобностью.

Как отмечалось выше, в 1959 г. мы произвели археологическую разведку на всех трех городках, в результате чего выяснилось следующее. Лоемский городок располагался на высоком мысу боровой террасы, полого спускавшемся к реке Лузе; с боковых сторон ограничен глубокими оврагами с крутыми скатами, а с напольной стороны защищен пересекающим мыс глубоким рвом. Площадь городища неоднократно распахивалась, а сейчас занята небольшой колхозной лесобиржей. Поэтому возможность раскопок была весьма ограниченной. Несколько шурфовок оказались неудачными, но в северо- восточном углу, подле рва, на небольшой глубине (40-50 см) прослеживается культурный слой - в ярко окрашенном (оранжевого оттенка) песке глинистая и углистая прослойка. У самого края рва - также углистая прослойка и слабые признаки перегнившего дерева (остатки тына). В общем, Лоемское городище - мало выразительный памятник. По всей видимости,

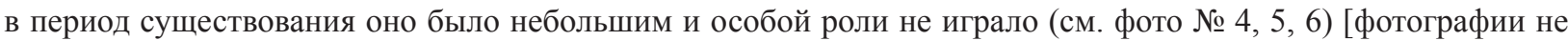
публикуются].

Более крупными и важными в целях обороны были городки Спасский и Объячевский. К сожалению, мы можем лишь предполагать вероятное место расположения Объяческого городка - крутом берегу Лузы в центре современного Объячева, подле дома культуры (в здании бывшей церкви). В обрыве берега, ниже беседки, нами подобраны металлические шлаки, кусок распадающегося на чешуйки железа, старинный кованный гвоздь и два тонких фрагмента керамики, сделанной на гончарном кругу, из хорошей глины с примесью тщательно дробленного гранита. Керамика несомненно имеет отношение к городищу, так как состав текста, форма отвернутого наружу венчика сосуда, аналогична керамике с Ибского городища того же времени, изученного нами в 1958 г.

Наибольший интерес представляет Спаспорубское городище (по-местному, «Городок»), давшее значительные находки, главным образом керамику, орудия труда, остеологический материал. Городок расположен немного ниже бывшей церкви на крутом мысу боровой террасы, вытянутом вдоль течения р. Лузы. Мыс ограничен с трех сторон глубокими оврагами с почти отвесными скатами, с четвертой стороны мыс узким перешейком соединяется с основным материком, но пересечен здесь искусственным рвом. Западная, с пологим понижением от центра, часть мыса поросла крупным еловым лесом (см. фото № $7,8,9,10)$ [фотографии не публикуются].

Проникнув на городище через перешеек и ров, в северо-восточном углу справа у входа, находим небольшое возвышение сильно перегоревшим слоем (остаток ворот башни), площадью $3 x 4$ м; у его подножья большая кладоискательская яма, в которой пионеры будто бы нашли каменное ядро. Ровная, собственно городищенская территория занимает площадь в 720 кв. м (20 х 36), но ясно выраженный культурный слой имеется только в северной половине этой территории, шириною в 3,5-4 м, длиною в 17 м. Центр городища, его южная 
и юго-западная части такого слоя не содержит. Нами заложено свыше десятка шурфов и на основе их показаний произведены два полных и два частичных раскопа. Обнаружено жилое сооружение типа полуземлянки с печью-каменкой, остатками стен, пола, перекрытий в виде сильно перегнившего дерева (тесаных плах?). На этом месте сделан раскоп длиною 5 м, шириною 3,3 м, глубиною до 60-70 см. Стратиграфия раскопа следующая: дернина, прослойка плотно слежавшейся глины толщиною до 20-30 см. (остаток засыпки крыши?), темный слой I, печная глина вместе с обожженными валунами, темный слой II (печной под?), материковый белый песок.

Находки вещей (керамики, различных костей) начинаются сразу же под первым глиняным слоем в I темном слое, но главным образом - в очаге и нижнем темном слое. Основная масса костей животных сосредоточена при устье печи, наиболее крупные фрагменты керамики - перед печкой слева и справа, в самой печи найдены два бруска для заточки ножей и топоров, в подходе к печке - христианский крестик из белого металла и медвежий клык. Выяснилась и такая деталь, что печь-каменка устьем была направлена к расположенному как раз напротив входу, т.е., в общем, это небольшое жилье, пристроенное, надо полагать, вплотную к крепостному тыну, весьма напоминало обычные баньки и охотничьи избушки коми.

Проверочные шурфы, заложенные в нескольких метрах справа и слева от жилья, дали культурный слой на меньшей глубине и менее интенсивный в виде прослойки гнилого дерева, угольков, глинистых вкраплений, немногочисленной и очень фрагментарной, т.е. попросту выброшенной из жилья битой керамики.

Среди остеологических сборов преобладают кости домашних животных, птиц и рыб. Находка единичного медвежьего клыка свидетельствует об использовании его в качестве амулета, что подтверждается и этнографическими данными. Подавляющее большинство найденных черепков происходит от сосудов, сделанных от руки, причем в многих случаях довольно грубо. Это были горшки средней величины (наиболее крупные диаметром до 26 см), плоскодонные, с выпуклым туловом и различной формой венчика (чаще прямостоячим или слегка отвернутым наружу) при незначительном развитии плечиков. Тесто керамики состояло из плохо отмученной глины и примеси грубой дресвы. Орнамент не наносился. Исключением является один довольно крупный горшок, изготовленный на гончарном кругу, имеющий хорошо выраженные плечики и прямостоячий высокий венчик, а также типично славянский волнистый орнамент, опоясывающий плечики сосуда.

Керамические комплексы Спаспорубского, Объячевского и Ибского (на Сысоле) городков хорошо датируются, весьма выразительны и могут послужить хорошим материалом для характеристики одного из элементов культуры коми XV-XVII вв. Несомненно, массовая глиняная посуда изготовлялась без помощи гончарного круга, от руки, вероятно женщинами в каждом отдельном хозяйстве. Но была и посуда, изготовленная на круге по русскому образцу. Видимо, кое-где, особенно в таких важных погостах как Объячево, Спаспоруб, Иб и др. существовали люди, имевшие гончарный круг. Во всяком случае, вряд ли в это время глиняная посуда привозилась в Коми край откуда-нибудь издалека.

В непосредственном соседстве со Спаспорубским городищем, на месте, где существовала церковь и старинное, давным-давно заброшенное кладбище, в обрыве берега обнаружены остатки сгоревшего дома. Здесь хорошо прослеживаются развалины глинобитной печи, фрагменты от раздавленных мелых горшков, некоторые со следами от выгоревшей пищи, кости животных, остатки оконной слюды. Найдены также точильный брусок и медвежий зуб (резец). В общем, комплекс находок такой же, что и на городище; может быть это синхронные памятники.

В период экспедиционных работ мы интересовались историей населенных пунктов (Прилузского и Летского районов). Произведена перепись всех селений по их названиям не только не только официальным, но и традиционным местным. Коли исключить недавно возникшие рабочие поселки, то основная масса коми-зырянских и русских деревень существует издавна. Это видно на примере Лоймы, Спаспоруба, Объячева, Ношуля.

Взять, к примеру, населенные пункты Лоемского сельсовета по современным данным в сопоставлении со свидетельствами переписной книги 1645 г. Получается весьма примечательная картина:

\begin{tabular}{|l|l|l|}
\hline \multicolumn{2}{|c|}{ Современные деревни } & \multirow{2}{*}{ Деревни_середины XVII века } \\
\cline { 1 - 2 } \multicolumn{1}{|c|}{ названия официальные } & \multicolumn{1}{|c|}{ названия местные } & Гавриловская \\
\hline Гавриловская & Верх & Иванова \\
\hline Ивановская & Чарковчи & Митинская \\
\hline Степановская & Митёнки & Галахтионовская \\
\hline Галактионовская & Макаровчи & Филипповская \\
\hline Филипповская & Жебавчи & Кузнецова \\
\hline 1-я Кузнецовская & Кулига & - \\
\hline 2-я Кузнецовская & Кулига & - \\
\hline Пентюра & Пентюра & \\
\hline
\end{tabular}




\begin{tabular}{|c|c|c|}
\hline Горяиновская & Горяиновская & Горяиновская \\
\hline Семушинская & Семушата & - \\
\hline Кондыревская & Кондыревская & Кондыревская \\
\hline Карповская & Бородкинчи & Карповская \\
\hline 1-я Семеновская & Ефимовчи & Семеновская \\
\hline 2-я Семеновская & Ефимовчи & - \\
\hline Старчевская & Пакшёнки & Старцовская \\
\hline Лойма & Лойма & Лоемский погост \\
\hline Визилевская & Гришёнки & Визилевская \\
\hline Уркинская & Деревенщина & Уркинская \\
\hline Миленская & Милёнки & - \\
\hline Заостровская & Борисовчи & Борисовская \\
\hline Запольская & Заполье & Запольская \\
\hline Вотинская & Шорошёнки & Вотиновская \\
\hline Перенская & Перенская & - \\
\hline Тарасовская & Тарасовчи & Тарасовская \\
\hline Ракинская & Петковчи & Ракино \\
\hline Козловская & Зеленки & Козловская \\
\hline Грамоковская & Васильевчи & - \\
\hline Тарбеевская & Еременки & Тарбеевская \\
\hline Матвеевская & Некрасовчи & Матвеевская \\
\hline Прислон & Юденки & Прислон \\
\hline Гарь I & Гарь & Гарь \\
\hline Гарь II & Гарь & - \\
\hline
\end{tabular}

Простое сопоставление показывает, что лишь некоторые современные деревни не названы переписной книгой 1645 г., а именно: Пентюра, Семушинская, Миленская, Перенская, Грамоковская, но, возможно, что часть их существовала уже в середине XVII в. под иным названием, так как в упомянутой книге помимо перечисленных фигурируют и такие деревни, как Рагозино, Худутовская, Омельяново, Помосово тож, Данилова, Тимофеевская, Захаровская и др.

Примерно такая же картина наблюдается в Спаспорубе, Объячеве и Ношуле. Многие здешние деревни известны с середины XVII в., но не всегда под теми же названиями, что и в настоящее время. Современный Ношульский сельсовет объединяет населенные пункты: Бор I и III, Улчекшамӧдпӧл, Тереховская, Лябовская, Климовская, Самкоччой, Горбуновская, Яковлевская, Якушинская, Кузминская, Десятка, Девятка, Лихачевка, Сидорчой, Сонсикт, Юруксикт, Петидворка, Косьволок, Починок Левский. Из них 9 под такими названиями упоминаются в 1645 г., но в это время в Ношуле существовали и другие деревни, в частности, Обрамово, Кондратовская, Козгорт, Титовская, которые впоследствии, конечно, не исчезли, а получили иные названия, существующие и поныне.

Поэтому не удивительно, что в памяти старожилов совершенно исчезли какие-либо достоверные представления о времени и условиях возникновения крупнейших и старейших прилузских сел, а если на сей счет кое-что и сообщается, то лишь в форме легенд. Так жители Ношуля дают следующую этимологию названия своего села: Ношуль, по-местному, Ношоль, назван по здешней речке Ношолке, по берегам которой в прошлом произростало много липы, с нее драли корье (по-коми «шуль»), поэтому, дескать, первые русские, побывавшие здесь и удивленные обилием хорошего корья, воскликнули «но и шуль», что и стало собственным именем. Имеется и другая, сходная этимология: Ношуль происходит от выражения «ноша шуль» как свидетельство торговли ношульцами вязанками липового корья. Само собой разумеется, что подобные разъяснения слишком наивны, чтобы их принимать всерьез.

Жители Объячева называют свое село Абъячой, но что это название означает, никто толком не знает. На помощь приходит лингвистический анализ. Имя это явно состоит из двух частей «абья» и «чой», причем последняя означает гору. По весьма вероятной догадке лингвиста В.А. Сорвачевой, Абъячой означает крутую гору, точнее высокий, отвесный мыс. Действительно, Объячой расположено на очень высоком берегу р. Лузы, господствующем над окружающей местностью.

В с. Занулье нами написаны интересные генеалогические предания, уводящие историю села в глубь веков. В переписной книге 1645 г. упоминаются деревни: в Подкиберском подволовье дер. Вишаковская, другое Вышековское, Глебовская, Спиринская над речкою над Нюлой, другое Спиринское, третье Спиринское, Не- 
порть, Новоселка. Это первое известное нам упоминание населенных пунктов нынешнего Занульского сельсовета. Местные предания уточняют письменные свидетельства. Оказывается, никакой дер. Вишаковской здесь нет, а существует Мишаково (или Подкиберье), через которое в прошлом проходила дорога с Объячево на Кибру (Куратово). Деревня эта считается самой старой среди других населенных пунктов. Центральной частью Занулья всегда считалась дер. Спиринская (отсюда и дореволюционная волость Спиринская), но лоемские и спаспорубские крестьяне, отправляясь сюда по хозяйственным делам, обычно говорили, что едут «за Нюлу» (речку, впадающую в Лузу несколько ниже Спиринской). Это и дало современное название селу и сельсовету.

По преданиям, первыми из современных фамилий в Занулье появились Мокиевы (братья Матвей и Алексей), родом из русской Лоймы. Они заняли лучшие участки земли, пригодные для распашки и сенокоса. Их потомки, распадающиеся на две ясно различимые ветви, до сих пор считаются кровными родственниками. Позднее здесь обосновался Леонтий Потапов, пришедший неизвестно откуда, потомство которого составляет одну из местных коренных фамилий. Третьей по времени появления была фамилия Вязов, также занесенная со стороны. Ее родоначальником считается ссыльный или беглый, вначале скрывавшийся в лесу, а затем поселившийся в Занулье и женившийся на здешней женщине. Нынешние Вязовы ведут свою родословную от трех предков - Кирилла, Осипа и Павла. За последние сто лет в Занулье появились следующие фамилии: Коковкин, Попов, Яборов, Марков, Юхнин из Спаспоруба; Федюнев и Хотемов из Векшора (Читаевский с/с); Захаров из соседней дер. Мишаково. О давностях их проживания в Занулье свидетельствует их родословная. Так, Хотемовы насчитывают уже четыре поколения - от Ильи, Михаила, Афанасия и Михаила. Родословная Захаровых: Василий-Федор-Николай-Алексей-Александр.

Летка заселялась коми и русскими много позднее Прилузья. Переписная книга 1645 г. сообщает: «Тое же волости Луцкие Пермцы на речке на Летке на Вятском волоку погост Ляцкой на черном лесу. А поселились же крестьяне после прежних писцов (после 1620 г.) вновь, а по дозору 128 году те крестьяне пашню пахали наездом из оброку». В середине XVII в. на Летке кроме одноименного погоста были деревни Кочергинская, Даниловская, Урютно тож на р. Волоснице, Слудка и пустошь на месте дер. Тороповской. Согласно переписи 1710 г. в этом районе существовали погост и 12 деревень и починков с 27 дворами и 149 человек мужского пола, т.е. население было все еще незначительным. Наряду с упомянутыми выше, существовали следующие деревни: Березовка, Королевская, Талицкая, Черемховская, Прокопьевская. Они же перечисляются в ревизских сказках 1747 г. [29].

Многие населенные пункты современного Летского района возникли позднее середины XVIII в., в основном в последующем столетии. Деревни Слудка и Прокопьевка обросли «сиктами» и превратились в сельсоветы. В пределах Гурьевского с/с старинными являются только три деревни - Талица, Корольки и Березовка. Остальные - Романовка, Ичет-туй, починки Пронинский и Ивановский, ровно как и сама Гурьевка (центр сельсовета) - появились много позднее. В Мутницком с/с самым старым населенным пунктом является Черемуховка, а всех деревень здесь 17. С аналогичной картиной мы сталкиваемся в Летском сельсовете, который объединяет многие деревни вокруг райцентра, по дороге на Мураши (Бебера, Крутотыла) и в сторону Ношуля на Летско-Лузском волоке (Гостиногорская, Осиновка, Поромшор и др.). В переписях XVIII в. эти населенные пункты не фигурируют и впервые появляются лишь в волостной отчетности XIX - нач. XX в.

То же самое следует в целом сказать о Ловлинском и Верхолузском сельсоветах. Волок, разделяющий бассейн Лузы и Летки, использовался для транспортировки вятских товаров (главным образом хлеба) издавна, по крайней мере, с XVII в. Однако населенные пункты стали появляться здесь только после проведения постоянного зимне-летнего тракта. По данным 1825 г. по этому тракту существовали мелкие (в 1-2 дв.) починки Гостиногорской, Поромшор, Дальшор, Старцев луг, Гуменцы, Перкурьевка, Вазюг, тяготевшие к Кочергинской волости, т.е. к Летке [30]. Заселение тракта со стороны Ношуля началось позднее. В 1840 г. на всем пути от д. Гостиногорской до Ношуля не было ни одного населенного пункта [31]. Но в 1876 г. здесь появились деревни Ловля, Кривуша, Девятка [32], а к 1886 г. новые починки Сокся и Важгорт [33]. Судя по составу местных фамилий, основателями селений по Летско-Лузскому тракту были выходцы из Кочергинской и НошульскоКайтановской волостей [34].

Первые починки в верховьях Лузы, ныне входящие в состав Летского р-на, возникли в конце 50 - начале 60 -х годов прошлого столетия. По сведениям Кайтановского волостного правления на 1863 г., в этой глухой и труднодоступной местности существовали починки Верхне (Верхолузье), Черный мыс, Ула, в которых проживало 16 семейств, переселившихся из Ношуля и Объячева [35]. В 1886 г. в Верхолузье отмечены населенные пункты: Кузюк, Тылай, Луза, Бадья, Черный мыс, Ула, Починок Вахнинский, Нонева, Худышина, с общим числом населения в 395 человек, обоего пола [36].

Следует отметить, что для сопредельной полосы Коми края и Вятской земли в конце XIX - нач. XX вв. был характерен так наз. «хуторской» (мелкими починками) тип поселения. В период столыпинщины законодательно было подтверждено право крестьян Вологодской и Вятской губернии при желании выселиться 
на починки в этом районе. Например, в 1911 г. Главное управление землеустройства и земледелия представило 230 переселенческих хуторских участков на 690 душевых долей в Опарино- Моломском районе [37], т.е. на границе Коми края. Немалое число русских и коми крестьян воспользовались этим разрешением и мелкими группами расселились по починкам. Возникли поселки со смешанным коми-русским населением. Таковы деревни Бебера (на Мурашинском тракте), Гурейвож и Слота (в пределах совр. Мутницкого с/с).

Одним из важных моментов в нашей работе явилось установление фамильного состава населения Прилузского и Летского районов, анализ которого позволяет сделать существенные выводы по этнической истории, в особенности по вопросу о коми-русских этнических связях. Ниже дается подробный список коренных фамилий по всем обследованным сельсоветам.

\section{Фамилии Лоемского сельсовета}

(Население русское)

\begin{tabular}{|l|l|l|l|}
\hline [Фамилия] & [Чило семейств] & [Фамилия] & [Чсло семейств] \\
\hline Иевлев & 68 & Безносиков & 10 \\
\hline Куликов & 47 & Пашкин & 10 \\
\hline Чужмаров & 36 & Зорин & 8 \\
\hline Шехонин & 31 & Рожицын & 8 \\
\hline Низовцев & 29 & Шумилов & 7 \\
\hline Киршин & 24 & Савинов & 7 \\
\hline Михеев & 21 & Жебов & 7 \\
\hline Бородкин & 20 & Макаровский & 6 \\
\hline Помысов & 19 & Марков & 6 \\
\hline Сюткин & 19 & Капустин & 6 \\
\hline Карманов & Ерилов & 5 \\
\hline Вилежанинов & 18 & Кукольщиков & 5 \\
\hline Васильев & 17 & Яборов & 5 \\
\hline Лобанов & 16 & Борисов & 5 \\
\hline Чарков & 15 & Пантелеев & 5 \\
\hline Машуков & 14 & Смолев & 4 \\
\hline Тырышкин & Заварин & 4 \\
\hline Мокиев & 14 & Старцев & 2 \\
\hline
\end{tabular}

А также [имелся] ряд одиночных фамилий. Некоторые из этих фамилий известны по переписной книге 1645 г., а именно: Иевлев, Ерилов, Капустин, Помысов, Карманов, Жебов, Марков, Тырышкин, Макаров. Фамилия Сюткин упоминается в документах еще раньше: в 1588 г. в Лузской Пермце (вероятнее всего, в Лойме) проживал Василий Фомин сын Сюткин [38].

Фамилии Спаспорубского сельсовета

(население на нижнем конце - русское, на верхнем конце - коми).

\begin{tabular}{|l|l|l|l|}
\hline \multicolumn{2}{|c|}{ Русские } & \multicolumn{2}{c|}{ Коми } \\
\hline [Фамилия] & [Число семейств] & [Фамилия] & [Исло семейств] \\
\hline Безносиков & 55 & Безносиков & 34 \\
\hline Ракин & 3 & Ракин & 51 \\
\hline Лобанов & 3 & Лобанов & 55 \\
\hline Карманов & 15 & Карманов & 2 \\
\hline Яборов & 10 & Яборов & 1 \\
\hline Марков & 11 & Марков & 1 \\
\hline Попов & 16 & Попов & 4 \\
\hline Латышев & 7 & - & \\
\hline Юхнин & 5 & Юхнин & 11 \\
\hline Смолев & 6 & Смолев & 1 \\
\hline Протопопов & - & \\
\hline
\end{tabular}




\begin{tabular}{|l|l|l|l|}
\hline Иевлев & 4 & Иевлев & 2 \\
\hline Яйцев & 3 & Яйцев & 19 \\
\hline Куликов & 2 & - & \\
\hline Низовцев & 2 & - & \\
\hline Дымов & 1 & - & \\
\hline- & & Старцев & 45 \\
\hline- & & Урнышев & 36 \\
\hline- & & Фомин & 24 \\
\hline- & & Игутов & 22 \\
\hline Кукольщиков & 1 & Кукольщиков & 18 \\
\hline Зорин & 1 & Зорин & 14 \\
\hline- & & Тимонин & 14 \\
\hline Клементьев & Клементьев & 12 \\
\hline- & 6 & Калов & 10 \\
\hline- & & Плесовский & 10 \\
\hline- & & Езимов & 9 \\
\hline- & & Шиханов & 9 \\
\hline- & & Кирпулев & 8 \\
\hline
\end{tabular}

Анализируя перечисленные фамилии, можно сделать интересные наблюдения, в особенности, если сопоставить фамилии Спаспоруба и Лоймы. Во-первых, среди русской части Спаспоруба существует немало фамилий, типичных и для Лоймы: Безносиков, Зорин, Иевлев, Карманов, Кукольщиков, Куликов, Лобанов, Марков, Низовцев, Смолев, Яборов. Собственно спаспорубскими русскими фамилиями являются: Дымов, Клементьев, Латышев, Попов, Протопопов, Ракин, Юхнин, Яйцев. Однако Ракины некогда проживали и в Лойме, так как в 1645 г. здесь отмечена деревня Ракино, в которой проживало три семейства Ракиных.

Во-вторых, целый ряд спаспорубских фамилий одинаково присущ коми и русским (см. таблицу), причем нередко первые преобладают над последними: коми Лобановы, Ракины, Клементьевы, Кукольщиковы, Зорины, Юхнины, Яйцевы. В-третьих, одинаковые фамилии преобладают в нижней и центральной части села, где коми и русские живут бок о бок, а в деревнях на верхнем конце села и, в особенности, в поселках по р. Поруб, где состав населения (коми) более однороден, существуют только местные фамилии, русским соседям не свойственные.

Иначе говоря, приведенная ономастика дает хороший материал для конкретного раскрытия весьма широких коми-русских этнических взаимоотношений в полосе этнической границы. Известные нам документы первой половины XVII в. сообщают о следующих фамилиях Спаспоруба: Авшаров, Бардуков, Горбунов, Зорин, Езимов, Елкин, Ефимов, Калов, Капчаков, Лобанов, Ливаев, Лихачев, Макаров, Марков, Петряшин, Рудаковых, Сладков, Старцев, Силин, Сабуров, Тарасов, Урнышев, Яйцев (подчеркнутые фамилии существуют и по сей день [39].

Фамилии Объячевского сельсовета. (коренное население причисляет себя к коми).

\begin{tabular}{|c|c|c|c|}
\hline [Фамилия] & [Число семейств] & [Фамилия] & [Число семейств] \\
\hline Шулепов & 94 & Худяев & 23 \\
\hline Туголуков & 76 & Шаглеев & 15 \\
\hline Леканов & 68 & Паюсов & 15 \\
\hline Лихачев & 66 & Чегесов & 11 \\
\hline Стрекалов & 64 & Смолев & 11 \\
\hline Елин & 40 & Сердитов & 9 \\
\hline Кузнцов & 37 & Федюнев & 8 \\
\hline Иевлев & 35 & Андреев & 7 \\
\hline Панев & 35 & Можегов & 6 \\
\hline Беляев & 33 & Багин & 4 \\
\hline Оботуров & 30 & Липнин & 4 \\
\hline Шучалин & 25 & Вахрамеев & \\
\hline Ложкин & 25 & & \\
\hline
\end{tabular}


Кроме того, русскими указаны: Иевлевы - 7 сем., Безносиковы - 3 сем., Чужмаровы - 3 сем., Вилижаниновы - 2 сем., Сюткин, Шехонин.

Нетрудно заметить, что объячевские фамилии сугубо местные, в основном отличные от спаспорубских и лоемских. C XVII в. в Объячево проживают Шучалин, Кузнецов, Панев, Лихачев, Леканов, Шулепов, Федяев, Паюсов, Туголуков. Тем не менее ономастические связи Объячева с нижней Лузой несомненны. Иевлевы и Смолевы - русские и коми - издавна проживают также в Лойме и Спаспорубе. Лихачевы и Елины, в значительном количестве представленные в Объячево, отмечены в середине XVII в. в Спаспорубе. Любопытно, что характерная фамилия Оботуров вполне может быть сопоставлена с именем устюжанина Оботура того же столетия [40].

Но в наибольшей степени ономастика Объячева перекликается с фамилиями Читаевского с/с, с одной стороны, и Ношульского с/с, с другой, что видимо из нижеследующих таблиц.

\section{Фамилия Читаевского сельсовета}

(население коми)

\begin{tabular}{|c|c|c|c|}
\hline [Фамилия] & [Число семейств] & [Фамилия] & [Число семейств] \\
\hline Андреев & 56 & Вахрамеев & 9 \\
\hline Кустышев & 41 & Шучалин & 8 \\
\hline Хотемов & 30 & Новиков & 7 \\
\hline Дымов & 22 & Шулепов & 4 \\
\hline Федюнев & 21 & Шаглеев & 4 \\
\hline Елин & 13 & Русских & 2 \\
\hline Галев & 12 & Тарачев & \\
\hline Туглуков & 12 & Чегесов & \\
\hline Тюрнин & 11 & & \\
\hline
\end{tabular}

Простое сопоставление показывает, что из 17 основных читаевских фамилий только 8 является местными: Кустышев, Хотемов, Дымов, Галев, Тюрнин, Новиков, Русских, Тарачев. Остальные аналогичны объячевским фамилиям и, вероятно, происходят от последних. Привлекают внимание фамилии Русских и Тюрнин. Первые, по преданию, действительно происходят от русского предка, в давние времена поселившего в дер. Малый Вильгорт. Тюрнины известны по Вычегде, причем род их идет от духовных лиц русского происхождения, основавших в XVII в. Ульяновскую пустынь на верхней Вычегде, и впоследствии многие Тюрнины были священнослужителями. Вероятно, и читаевские их однофамильцы являются потомками служителя культа.

Фамилии Ношульского сельсовета (коренное население коми)

\begin{tabular}{|c|c|c|c|}
\hline [Фамилия] & [Число семейств] & [Фамилия] & [Число семейств] \\
\hline Можегов & 75 & Игнатов & 14 \\
\hline Вахнин & 63 & Супрядкин & 13 \\
\hline Шулепов & 53 & Костылев & 11 \\
\hline Рубцов & 38 & Горбунов & 7 \\
\hline Трофимов & 35 & Лихачев & 6 \\
\hline Иевлев & 30 & Верещагин & 6 \\
\hline Сердитов & 29 & Шилов & 5 \\
\hline Никулин & 18 & Бобров & Ортяков \\
\hline Ичеткин & 17 & & \\
\hline Тарасов & 15 & & \\
\hline
\end{tabular}

В Ношуле, таким образом, имеются некоторые фамилии. Родственные объячевские: Можегов, Шулепов, Сердитов, Иевлев, Лихачев. К ним следует присоединить Вахнина, Ичеткина и Горбунова, проживающих в Объячеве и Ношуле в середине XVII в. Может быть, все эти фамилии по своему происхождению объячевские, но затем распространившиеся в Ношуле в связи с переселением их носителей поближе к знаменитой торговле Ношульской пристани.

Коренное население Занулья, Читаева, Объячева и Ношуля, говорящее на коми языке, считает своими предками исключительно местных коми. Но целый ряд фамилий, не говоря уже об упомянутых выше занульских Мокиевых и Вязовых, читаевских Тюрниных и Русских, объячевских Оботуровых, Иевлевых и Смо- 
левых, прозрачно намекает на участие в происхождении их носителей русских элементов. Действительно, в 1591 г. известен «Василий Иванов сын Невзоров вятчанин из Лузские Пермьцы из Объячева» [41], в 1645 г. здесь же проживали крестьяне Степанка сын Вятка и Капустин. Оба вятчанина безусловно были русскими, а Капустины и в XVII в. и по сей день являются коренными жителями русской Лоймы. Среди жителей Ношуля в 1645 г. были Горяинов и Смолев, но одновременно в Лойме существовала дер. Горяиновская, явно названная так по имени основателя, и крестьяне Смолевы.

Исследования 1959 г. дают возможность показать еще шире выразительные этнические корреспонденции русской Устюжской земли, в том числе и Лоймы, с коми-зырянской Киброй и Сысолой. Так, обращают на себя внимание сходные названия деревень Рай в Лойме и Спаспорубе, Раевсикт в Кибре, Раевская (Раева) гора в Визинге и фамилия Раевский в Визинге, Межадоре и Пыелдине. В 1585 г. в Кибринском погосте была деревня Ентула (Энталь), по названию живо напоминающая р. Енталу и Ентальскую русскую волость в бассейне p. Юг. Кстати, фамилия Югов зарегистрирована в Кибре переписной книгой 1720 г. В это же время в Кибре существовала редкая фамилия Момотов [42]. Но во вкладной книге устюжского Михаила-Архангельского монастыря под 1594 г. ясно сказано: «с Югу Михаил Гаврилов сын Момотов» [43].

В начале XVII в. в Лоемском погосте была дер. Колеговская, в XVII-XVIII вв. крестьяне Колеговы проживали в Кибре, Ибу и Визинге, где имелась к тому же дер. Колегова гора. Фамилия Карманов распространена в Лойме, Визинге, Палаузе и Ужге; фамилия Безносиков - на Лузе в Вымске, Лойме и Спаспорубе, а на Сысоле - среди устюжан и в Визинге.

Подобные корреспонденции не могут быть отнесены за счет случайных совпадений: их массовость и определенная целенаправленность свидетельствуют о взаимообмене населением между соседними народами - коми и русскими. Известно, что в первой половине XVII в. Лузская Пермца сильно запустела и поэтому часть ее жителей, мигрируя, могла очутиться на Сысоле среди коми. Неслучайно, конечно, одна из визингских деревень называется Рочево, т.е. «русская», с которой связана местная фамилия Рочев.

Данные ономастики имеют важное значение в разрешении вопроса о заселении коми и русскими бассейна р. Летки. Так как земледельческая колонизация этого района происходила довольно поздно, в XVIIXVIII вв. (см. выше), когда крестьянские фамилии приобрели сравнительную устойчивость, то распространение сходных, наиболее характерных фамилий на новых территориях почти всегда являлось свидетельством миграций их носителей из определенных пунктов. Нижеследующий фактический материал убедительно подтверждает этот вывод.

Современные фамилии коренного населения Летского района таковы:

\begin{tabular}{|c|c|c|c|}
\hline [Фамилия] & [Число семейств] & [Фамилия] & [Число семейств] \\
\hline \multicolumn{4}{|c|}{ В Летском сельсовете (вместе с бывшим Гостиногорским с/с ) } \\
\hline Попов & 135 & Косолапов & 7 \\
\hline Кетов & 75 & Перминов & 4 \\
\hline Пантелеев & 44 & Ичеткин & 4 \\
\hline Мороков & 35 & Лобанов & 3 \\
\hline Вахнин & 36 & Рубцов & 2 \\
\hline Турков & 27 & & \\
\hline \multicolumn{4}{|c|}{ В Мутницком сельсовете } \\
\hline Косолапов & 64 & Жигалов & 5 \\
\hline Рубцов & 48 & Дымов & 2 \\
\hline Иванов & 34 & Осипов & 2 \\
\hline Перминов & 34 & Киселев & 2 \\
\hline Плеханов & 27 & Потапов & 2 \\
\hline Лобанов & 15 & Кетов & 2 \\
\hline Черных & 7 & & \\
\hline \multicolumn{4}{|c|}{ В Гурьевском сельсовете } \\
\hline Черных & 133 & Жигалов & 16 \\
\hline Осипов & 75 & Потапов & 12 \\
\hline Сухогузов & 28 & Дымов & 11 \\
\hline Зизганов & 27 & Кетов & 3 \\
\hline Сидоров & 21 & Иванов & 3 \\
\hline
\end{tabular}




\begin{tabular}{|l|l|l|l|}
\hline \multicolumn{5}{|c|}{ В Слудском сельсовете } \\
\hline Осипов & 63 & Шулепов & 7 \\
\hline Мусанов & 24 & Москвин & 6 \\
\hline Гущин & 21 & Черных & 5 \\
\hline Иванов & 12 & Коснырев & 3 \\
\hline Ортяков & Югов & 3 \\
\hline Патракеев & 12 & Дымов & 2 \\
\hline
\end{tabular}

В Прокопьевском сельсовете (со слов соседнего населения): Ичеткин, Коснырев, Лобанов, Ортяков, Потапов, Трофимов, Осипов.

На основании анализа фамильных списков и при сравнении их со списками Прилузского района, а также при сопоставлении с показателями письменных источников мы приходим к интересным выводам. Во-первых, среди коми населения Летки распространено меньшее количество различных фамилий. В каждом сельсовете преобладающими являются всего несколько фамилий, носители которых, видимо, суть потомки первых переселенцев. В обширном Летском с/с таких фамилий шесть: Попов, Кетов, Пантелеев, Вахнин, Мороков и Турков; в Мутницком с/с пять: Косолапов, Рубцов, Иванов, Перминов, Плеханов; в Гурьевском с/с также пять: Черных, Осипов, Сухогузов, Зизганов, Сидоров; в Слудском с/с три: Осипов, Мусанов, Гущин; в Пркопьевском с/с две: Косныревы и Трофимовы.

Во-вторых, многие фамилии различных сельсоветов перекликаются между собой, что свидетельствует, с одной стороны, о том, что заселение Летки происходило из одних и тех же мест, а с другой, что на протяжении последних столетий на Летке происходило заметное перемещение местных жителей из одного селения в другое. В этом отношении нелишне сослаться, например. На ревизские сказки 1747 г., в которых указано, что из д. Слудки крестьяне Гущин переселился в соседнюю Прокопьевку, напротив из этого селения в д. Талицкую ушел Потапов, в Талицкую же перешел из д. Корольки С. Дымов; из д. Березовской переселились в Талицкую Черных, в Слудку - Югов. В д. Костровскую - другой Черных; из д. Талицкой ушли в Слудку Кетов и в дер. Хлыстовскую другой Кетов [44].

В-третьих, современные летские фамилии имеют многочисленные аналогии в Прилузье: Ичеткин, Рубцов, Ортяков, Вахнин (Ношуль), Дымов (Читаево), Лобанов и Пантелеев (Лойма). Документы XVII и XVIII вв., называющие имена ранних переселенцев на Летке, позволяет этот список еще расширить. По данным переписной книги 1678 г., в Летской слободке жили крестьяне: Жебов, Дмитриевых, Патракеев, Сысолетин, Лузянин, Шулепов, Осиповых, Иевлев, Стуков, Кокочиков, Ленеев, Зызанов (Зизганов?), Моров (Мороков?), Лобанов, Сухогузов, Сидоров, Черного (Черных?), Артемьевых (Ортяков?), Багин, Логинов, Помосов, Чукилев, Плехов, Потапов, Коснырев, Вологжанин, Иванов [45]. Здесь уже названы многие летские фамилии, существующие и поныне, но одновременно названы и позднее исчезнувшие, но, несомненно, связанные с Прилузьем: Жебов (ср. лоемскую Жебов), Помосов (Лойма), Шулепов, Иевлев, Сухогузов, Багин (Ношуль, Объячево). Примечательны фамилии топонимического характера - Лузянин, Сысолетин, Вологжанин, т.е. точно указывающие, откуда пришли на летку крестьяне с такими прозвищами.

К моменту переписи 1747 г. на Летке появились новые фамилии: Гущин, Жигалов, Трофимовых, Кетов, Плехов, Мусанов, Тушин, Корякин, Пыжьяков, Сибриных, Кырченов, Чесноков, Москвин, Югов, Важенин, Перминов [46]. Это, по всей видимости, были выходцы из различных мест, в том числе с рр. Юг, Вага и из Прикамья (Перминов). Что же касается Москвиных, то до сих пор в их семьях, проживающих в с. Слудка, существует предание о далеком предке, пришедшем из Москвы или Московского края.

Таким образом, в формировании коми населения Летки ровно как и Прилузья, приняли участие русские этнические элементы, которые, оказываясь в меньшинстве, рано или поздно озырянивались. Такое же явление наблюдалось в XIX - нач. XX вв. Почти все жители Летки считались коми, но во многих семьях или были живые выходцы из русской среды (обычно женщины), или сохранялась память о русском происхождении кого-либо из близких или дальних предков.

В целях конкретного выяснения данного обстоятельства мы просмотрели метрические книги Слудской церкви за $1871-75,1886-90,1901-05$ и 1913-18 гг., в которых содержатся сведения о регистрации браков. Почерпнутые сведения о смешанных коми-русских браках можно представить в виде нижеследующих таблиц.

\begin{tabular}{|l|l|}
\hline \multicolumn{2}{|c|}{ Вступили в брак в 1871-1875 гг. } \\
\hline д. Прокопьевки кр-н Коснырев (коми) & $\begin{array}{l}\text { Лекошского прихода Слободского уезда девица } \\
\text { (русская) }\end{array}$ \\
\hline поч. 3-го Федоровского кр-н Коряков (русский) & Поч. 2-го Федоровского девица Плехова (коми) \\
\hline
\end{tabular}




\begin{tabular}{|c|c|}
\hline \multicolumn{2}{|c|}{ В 1886-1890 гг. } \\
\hline с. Слудка кр-н Дымов (коми) & $\begin{array}{l}\text { поч. Веселый (Верхолузье) девица Лаветина } \\
\text { (русская) }\end{array}$ \\
\hline с. Слудка кр-н Гущин (коми) & поч. 1-го Федоровская девица (русская) \\
\hline поч. 2-го Федоровского кр-н Перминов (коми) & с. Монастырского Орловского у. девица (русская) \\
\hline \multicolumn{2}{|c|}{ В 1901-1905 гг. } \\
\hline д. Гурьевской кр-н Зизганов (коми) & поч. 3-го Федоровского девица Суслова (русская) \\
\hline поч. 3-го Федоровского Казаков (коми) & того же поч. Вжегова (коми) \\
\hline поч. Ивушинского Осипов (русский) & поч. 2-го Федоровского Плехова (коми) \\
\hline поч. при р. Зимней Сидоров (коми) & Верходворской волости Шишкина (русская) \\
\hline д. Березовки Черных (коми) & поч. 1-го Федеровского Сибрина (русская) \\
\hline с. Слудка Иванов (коми) & поч. 1-го Федоровского Оралова (русская) \\
\hline д. Прокопьевка Иванов (коми) & $\begin{array}{l}\begin{array}{l}\text { поч. Зимнинского Березовской вол. Казакова } \\
\text { (русская) }\end{array} \\
\end{array}$ \\
\hline поч. Прошкина Гущин (коми) & $\begin{array}{l}\text { д. Костровской Верходворского прихода Лузянина } \\
\text { (русская) }\end{array}$ \\
\hline с. Верходворье кр-н (русский) & д. Черемуховка Косолапова (коми) \\
\hline поч. Прошкина Гущин (коми) & поч. Кулижского Вологжанина (русская) \\
\hline Поч. 2-го Федоровского Скопин (русский) & Того же поч. Коснырева (коми) \\
\hline поч. Кулижского Вологжанин (русский) & Того же поч. Коснырева (коми) \\
\hline поч. Кулижского Вологжанин (русский) & с. Слудка Шулепова (коми) \\
\hline \multicolumn{2}{|c|}{ В 1913-1918 гг. } \\
\hline $\begin{array}{l}\begin{array}{l}\text { поч. Макаровского (около Мурашей) Домашкин } \\
\text { (русский) }\end{array} \\
\end{array}$ & д. Мутница Иванова (коми) \\
\hline поч. Изъшор Макаров (русский) & с. Березовка Ортякова (коми) \\
\hline поч. Лунвож Черных (коми) & Того же поч. Плюснина (русская) \\
\hline д. Мутница Иванов (коми) & поч. Слота Симакова (русская) \\
\hline д. Мутница Рубцов (коми) & поч. Слота Суслова (русская) \\
\hline д. Кулига Коснырев (коми) & Той же деревни Вологжанина (русская) \\
\hline
\end{tabular}

Приведенные свидетельства метрических книг лишь по одному приходу всего за несколько лет красноречиво рисуют картину весьма оживленных этнических связей разноязычного населения в полосе этнической границы. К этому следует добавить, что не только близкое соседство, но и тесные хозяйственные связи Летки с Вятско-Камского краем способствовали все большему расширению отмеченного этнического процесса. Население Летки хорошо знает русский язык и широко им пользуется, причем указывает, что и в прошлом, как вспоминают старожилы, не только мужчины, но и многие женщины свободно объяснялись по-русски. На вопрос, как же они сами объясняют это явление, мы обычно слышали: да ведь Вятка-то была рядом, всего в ста верстах по земскому тракту, по которому и летские жители постоянно ездили по своим хозяйственным делам в город и соседние с ним села да русские вятчане во многолюдстве наведывались в летские селения с товарами и по мастерству.

Как отмечалось выше, небольшое русское старожильческое население, сложившееся в XIX - начале $\mathrm{XX}$ вв., существовало и на самой Летке и в Верхолузье в непосредственном соседстве с коми. На Мурашинском тракте в 17 км от с. Летка расположена д. Бебера, в которой преобладают русские жители, но есть и коми. Фамильный состав их таков:

\begin{tabular}{|l|l|l|l|}
\hline [Фамилия] & [Число семейств] & [Фамилия] & \multicolumn{2}{|c|}{ [Число семейств] } \\
\hline \multicolumn{2}{|c|}{ Русские } & \multicolumn{2}{|c|}{ Коми } \\
\hline Агаляков & 3 & - & \\
\hline Скопин & 3 & - & 4 \\
\hline Косолапов & 2 & Косолапов & 3 \\
\hline- & & Лобанов & 3 \\
\hline- & & Мороков & 3 \\
\hline- & & Перминов & \\
\hline Журавлев & 2 & - & \\
\hline
\end{tabular}




\begin{tabular}{|l|l|l|l|}
\hline Окишев & 2 & - & \\
\hline Стариков & 2 & - & \\
\hline Чулков & 2 & - & \\
\hline Югрин & 2 & - & \\
\hline- & & Рубцов & 2 \\
\hline Коробейников & 1 & Коробейников & 1 \\
\hline Можегов & 1 & Можегов & 1 \\
\hline Старцев & 1 & Старцев & 1 \\
\hline Суслов & 1 & Суслов & 1 \\
\hline Белозеров & - & - & \\
\hline Бояринцев & 1 & - & \\
\hline Колпаков & 1 & - & \\
\hline Красницын & 1 & - & \\
\hline Крюков & 1 & - & \\
\hline Маракулин & 1 & - & \\
\hline Новгородцев & 1 & - & \\
\hline Солдатенков & 1 & - & \\
\hline Тимкин & 1 & - & \\
\hline Ярков & 1 & - & 1 \\
\hline- & & Коснырев & \\
\hline- & & Лихачев & \\
\hline
\end{tabular}

Из списка видно, что беберские коми являются уроженцами здешних мест, а русские - пришлые со стороны, но, как показывают информаторы, из ближайших районов Вятского края. За ряд истекших десятилетий некоторые коми обрусели (Косолаповы, Старцевы), напротив, отдельные русские озырянились Коробейниковы, Можеговы, Сусловы.

В пределах Мутницкого сельсовета есть две небольшие деревушки с характерными названиями: Русская Слота и Русский Гурейвож. Их население составляют: в первой деревне - Бакулин, Кассин, Кормщиков, Суслов (по 2 семейства), Бочкарев, Денисов, Казаков, Косолапов, Леванов, Симаков(по 1 семейству); во второй деревне - Зонов (2 семейства), Ивонин, Леушин, Макаров, Меньшиков, Новиков, Стариков (по 1 семейству). В большинстве случаев перечисленные фамилии встречаются в соседних вятских районах и селениях. Хотя мутницкие русские сохранили свой язык и этническое самосознание, все же они заметно сблизились с окрестными коми путем перекрестных браков и ныне сравнительно свободно говорят на коми языке.

Из-за трудности сообщения нам не удалось в 1959 г. посетить Верхолузье, но известно, что в здешних населенных пунктах - Веселом, Володичах, Уле - издавна коми и русские проживают совместно. В рукописи «Материалы экономического и этнографического обследования дер. Ула, произведенного С.Ф. Рубцовым в 1927 г.» читаем, например: «Население 214 чел., русские и коми, язык обоюдный (коми кыдъя роч)» [47]. Вероятно, в Верхолузье можно обнаружить такие же этнические явления, как и в летских селениях со смешанным старожильческим населением.

В программу экспедиционных работ нашего отряда входило также изучение современного этнического состава Прилузского и Летского районов. За годы советской власти, особенно в послевоенный период, здесь произошли большие изменения в сторону значительного роста народонаселения как путем естественного прироста, как и увеличения его за счет вновь приезжающих, главным образом русских, что привело, конечно, к существенным изменениям в этническом составе. В настоящее время не только подле райцентров, но и в пределах каждого сельсовета сложились рабочие поселки лесозаготовителей, механизаторов, рабочих РТС и различных предприятий районного значения. Население этих поселков, как правило, крайне смешанное. В старых коми населенных пунктах этнический состав более однороден, но и здесь проживает немалое число представителей иных национальностей. Каких либо особых препятствий, вроде национальной предупрежденности и других предрассудков, мешающим взаимным брачных связям, нами не наблюдалось. Напротив, лица брачного возраста различной национальности и профессий - рабочие, колхозники, интеллигенция - свободно образуют прочные семьи и воспитывают своих детей в традициях, представляющих гармоническое слияние русского и коми языка, быта и культуры. 
В подкрепление этнографическим наблюдениям сошлемся на цифровые данные, почерпнутые в похозяйственных книгах ряда сельсоветов. Например, в Читаеве рабочих и служащих насчитывается 60 семейств, из них коми -27 , русских -17 , коми-русских, т.е. таких, в которых один из супругов коми, а другой - русский, 16 семейств. В Мутницком сельсовете в поселке совхоза из 100 переписанных подряд семей оказалось: коми - 49, русских - 26, коми-русских - 25. Здесь же на усадьбе РТС из 39 семейств кадровых рабочих мы насчитали: коми -18 , русских - 12, смешанных -9 . В соседнем Гурьевском сельсовете подавляющее большинство население коми, а русских семейств всего 4, коми-русских - 2. Иное этническое состояние наблюдается в Слудском сельсовете, где расположен поселок механизированного лесопункта Якуньёль. Из 104 постоянно проживающих в поселке семейств записали себя: русскими -43 , коми -33 , украинцами -9 . Кроме того, есть смешанные семьи: коми-русских -15 , коми-украинских -2 и таких, где муж татарин, жена - коми, -2 . Среди слудских колхозников отмечено 11 семей, в которых муж или жена - русские, среди сельской интеллигенции подобных семей также 11 , а число русских -6 .

Несомненно, что в ближайшие годы, в связи с развитием промышленности и механизированного сельского хозяйства, русское население еще более, а прогрессирующий процесс этнического смешения усилится. Параллельно с этими явлениями нарастает влияние русского языка и быта на коренное население. Примечательно, что даже в семьях, имеющих разговорным языком коми, дети начинают овладевать русской речью еще до поступления в школу, перенимая ее от своих русских сверстников, но это имеет место пока там, где совместно проживают коми и русские. В деревнях с чисто коми населением первые навыки русского языка прививаются уже в школе, если, конечно, этому языку детей не учат в семье. В настоящее время даже среди людей старшего поколения, не исключая женщин, мало кто не знает или не понимает русского языка. Молодежь и люди среднего поколения (с. Летка) говорят по-русски совершенно чисто, иногда с большей или меньшей примесью коми вокализма, при разговоре друг с другом легко переходят с одного языка на другой (с коми на русский и обратно).

В Лоемском сельсовете по-прежнему почти все население русское, но все же, не в пример, прошлому, здесь начинают появляться коми семьи в числе приезжих рабочих и интеллигенции. Среди сельского населения мы насчитали также более десятка семейств, в которых местные уроженцы мужчины, главным образом молодые (1920-30-х годов рождения), женаты на женщинах коми. В таких семьях дети считаются русскими, говорят по-русски, а из коми языка знают лишь отдельные, слова и выражения.

\section{$* * *$}

Таковы основные материалы к этнической истории Прилузья и Летки, которые собраны нами в летний экспедиционный период 1959 г. На основании их мы приходим к выводу, что под углом зрения специфики формирования населения оба района следует рассматривать воедино, хотя заселялись они не одновременно. Действительно, в диалектном отношении и по происхождению коми население этих районов в основном однородно, если не принимать во внимание несущественных локальных различий. Правда, в Прилузье, в полосе этнической границы, смешение коми с русскими было большим, но ведь и в состав населения Летки вошло немало число русских. Что же касается современного состояния, то в Прилузье и на Летке описанные выше этнические процессы проявляются в сходных формах и развиваются в одном и том же направлении. Поэтому по линии этнической истории Прилузье и Летка в прошлом и теперь представляют собой единый этнографический район Коми АССР.

\section{Источники и литература.}

1. Историко-филологический сборник Коми филиала АН СССР. Сыктывкар, 1958. Вып. 4. С. 246.

2. По данным переписных книг 1625 и 1645 гг. Госуд. публ. библиотека [Российская национальная библиотека]. Рукописный фонд. Q IV. № 498.

3. ЦГАДА [РГАДА, Российский государственный архив древних актов]. Приказные дела старых лет, 1650-1652 гг. № 58.

4. Лыткин В.И. [Название работы отсутствует].

5. См. отчет Сысольской этнографической экспедиции 1958 г. и другие наши работы.

6. Чебоксаров Н.Н. Этногенез коми по данным антропологии // Советская этнография. 1946. № 2.

7. Жилина Т.И. Диалектологические материалы по Койгородскому району. Научный фонд Коми филиала АН СССР [Научный архив Коми НЦ УрО РАН]. Инв. № 1042.

8. Талицкий М.В. Верхнее Прикамье в X-XIV вв. М., 1951. С. 37-42. (Материалы и исследования по археологии СССР, № 22).

9. Смирнов А.П. Очерки древней и средневековой истории народов Среднего Поволжья и Прикамья. М., 1952. С. 207. (МИА СССР, № 28). 
10. Бадер О.Н., Оборин В.А. На заре истории Прикамья. Пермь, 1958. С. 202-203.

11. Дебец Г.Ф. Палеоантропология СССР. М.-Л.,1948. С. 217.

12. Грен А. Отчет научной экспедиции в Усть-Вымском районе 1924 г. Рукоп. фонд Коми республ. музея [Национальный музей Республики Коми]. Инв. № 138. Л. 14.

13. Макаров И.С. Волостные торжки в Сольвычегодском уезде в XVII в. Историч. зап. Вып. 1. 1937. С. 201.

14. Таможенные книги Московского государства XVII в. М., 1951. Т. II. С. 700, 805.

15. Книга большому чертежу. М.-Л., 1950. С. 167.

16. Макаров И.С. Волостные торжки в Сольвычегодском уезде в XVII в. С. 215.

17. Государ. публ. библиотека [Российская национальная библиотека]. Рукоп. фонд. Q IV. № 498.

18. Макаров И.С. Указ. соч. С. 201.

19. Богословский М. Земское самоуправление на русском Севере в XVII в. М., 1909. Т. I. С. 118.

20. Очерки по истории Коми АССР. Сыктывкар, 1955. Т. І. С. 64.

21. Акты исторические. Т. І. № 261.

22. Устюжский летописный свод. М.-Л., 1950. С. 84.

23. Там же. С. 85.

24. Там же. С. 95.

25. Там же. С. 92.

26. Яковлев А. Наместничьи, губные и земские уставные грамоты Московского государства. М., 1909. С. 124.

27. Устюжский летописный свод. С. 97.

28. Писцовая книга Лузской Пермцы 1645 г.

29. Рукоп. фонд Коми республ. музея [Национальный музей Республики Коми]. № 15. Лл. 320-336.

30. ЦГА Коми АССР [Национальный архив Республики Коми, далее - НАРК]. Ф. 65. Оп. 1. Д. 31.

31. ЦГА Коми АССР [НАРК]. Ф. 66. Оп. 1. Д. 36.

32. ЦГА Коми АССР [НАРК]. Ф. 180. Оп. 1. Д. 9.

33. ЦГА Коми АССР [НАРК]. Ф. 177. Оп. 2. Д. 13.

34. ЦГА Коми АССР [НАРК]. Ф. 64. Оп. 1. Д. 326.

35. ЦГА Коми АССР [НАРК]. Ф. 52. Оп. 1. Д. 33.

36. ЦГА Коми АССР [НАРК]. Ф. 177. Оп. 2. Д. 13.

37. ЦГА Коми АССР [НАРК]. Ф. 44. Оп. 1. Д. 179. Л. 22.

38. Шляпин В.П. Акты Велико-Устюжского Михаило-Архангельского монастыря. В.Устюг, 1913. Ч. II. С. 161.

39. Сенигов О.П. Памятники земской старины. СПб., 1903. С. 245; а также материалы переписной книги 1645 г.

40. Таможенные книги Московского государства XVII в. М., 1951. Т. II. С. 840. C. 164

41. Шляпин В.П. Акты Велико-Устюжского Михаило-Архангельского монастыря. В.Устюг, 1913. Ч. ІІ.

42. Научный фонд Коми филиал а[Научный архив Коми НЦ УрО РАН]. № 1020. Л. 172, 176.

43. Шляпин В.П. Акты Велико-Устюжского Михаило-Архангельского монастыря. Ч. ІІ. С. 174.

44. Рукоп. фонд Коми респбл. музея [Национальный музей Республики Коми], № 15, лл. 320-330.

45. Там же. Л. 312-313.

46. Там же. Л. 320-331.

47. ЦГА Коми АССР [НАРК]. Ф. Р-1010. Д. 24. Л. 3.

Публикащия И.Л. Жеребиова, Л.Я. Каневой 


\section{РЕЦЕНЗИИ. ХРОНИКА. БИБЛИОГРАФИЯ}

\section{СОДЕРЖАНИЕ ЖУРНАЛА «ИСТОРИЧЕСКАЯ ДЕМОГРАФИЯ» ЗА 2020 ГОД}

2020, № 1 (25)

\section{ЭТНОДЕМОГРАФИЧЕСКОЕ РАЗВИТИЕ СТРАН И РЕГИОНОВ В ИСТОРИЧЕСКОЙ РЕТРОСПЕКТИВЕ}

Черкасова М.С. (Вологда). Семья и термины родства в источниках XVI-XVII веков. С. 4-8. DOI: $10.19110 / 2304-5922-2020-1-4-8$

Леонтьев Е.В. (Минусинск). Образование домохозяйства в жизненном цикле служилых людей Красноярского уезда по данным податной ревизии 1722 года. С. 9-12.

DOI: $10.19110 / 2304-5922-2020-1-9-12$

Мацук М.А. (Сыктывкар). Мещане города Усть-Сысольска: уровень детности по ревизской сказке 1795 года. C. $13-14$. DOI: $10.19110 / 2304-5922-2020-1-13-14$

Сущий С.Я. (Ростов-на-Дону). Геодемографическая динамика русского населения закавказских территорий Российской империи в XIX - начале XX века. С. 15-20. DOI: $10.19110 / 2304-5922-2020-1-15-20$

Аргудяева Ю.В. (Владивосток). Миграции казаков и крестьян на юг Дальнего Востока России (вторая половина XIX - начало XX века). С. 21-26. DOI: $10.19110 / 2304-5922-2020-1-21-26$

Бурматов А.А. (Куйбышев). Смертность населения в Сибири накануне коллективизации. С. $27-31$. DOI: 10.19110/2304-5922-2020-1-27-31

Журавлев Н.Ю. (Сыктывкар). Миграционные процессы в Коми и их влияние на становление и развитие производства (с конца XV до середины XX века). С. 32-36.

DOI: $10.19110 / 2304-5922-2020-1-32-36$

\section{СОВРЕМЕННЫЕ ЭТНОДЕМОГРАФИЧЕСКИЕ ПРОЦЕССЫ}

Попова Л.А. (Сыктывкар). Тенденции разводимости населения в Республике Коми в ХХ веке и начале XXI века. C. $37-45$.

DOI: $10.19110 / 2304-5922-2020-1-37-45$

Байжиенова К.Т. (Нур-Султан, Казахстан). Оценка вляния развития системы здравоохранения на показатели демографии Республики Казахстан. С. 46-49.

DOI: $10.19110 / 2304-5922-2020-1-46-49$

\section{ИСТОРИЧЕСКАЯ ГЕОГРАФИЯ}

Гагиева А.К., Гагиев Н.Н. (Сыктывкар). Роль купеческого элнмента в освоении арктических территорий Европейского Севера России во второй половине XIX - начале XX века. К постановке проблемы. С. 50-53. DOI: $10.19110 / 2304-5922-2020-1-50-53$

\section{ИСТОРИОГРАФИЯ, ИСТОЧНИКИ, МЕТОДОЛОГИЯ}

Плотникова Г.Н., Плотников С.Н. (Пермь). «Екатеринбургская неделя» как источник по демографии населения Пермской губернии последней четверти XIX века. С. 54-58.

DOI: 10.19110/2304-5922-2020-1-54-58

Обедков А.П. (Сыктывкар). Отечественная научная школа географического градоведения: лидеры и направления научных исследований. С. 59-80.

DOI: $10.19110 / 2304-5922-2020-1-59-80$ 
Жеребцов И.Л. (СЫктывкар). ПАМЯТИ ВИКТОРА АНАТОЛЬЕВИЧА СЕМЁНОВА. С. 81-83.

DOI: $10.19110 / 2304-5922-2020-1-81-83$

\section{РЕЦЕНЗИИ. ХРОНИКА. БИБЛИОГРАФИЯ}

Содержание журнала «ИСТОРИЧЕСКАЯ ДЕМОГРАФИЯ» за 2019 год. С. 84-85.

ПРАВИЛА ДЛЯ АВТОРОВ журнала «Историческая демография». С. 86-87.

2020, № 2 (26)

\section{ЭТНОДЕМОГРАФИЧЕСКОЕ РАЗВИТИЕ СТРАН И РЕГИОНОВ В ИСТОРИЧЕСКОЙ РЕТРОСПЕКТИВЕ}

Семенов В.А, Вишнякова Д.В. (Сыктывкар). Демографические аспекты истории коми крестьянских родов Налимовых и Жаковых в конце XVIII - начале XX века. С. 4-7.

DOI: $10.19110 / 2304-5922-2020-2-4-7$

Игнатова Н.М. (Сыктывкар). Численность и половозрастной состав спецпереселенцев-«бывших кулаков» в Республике Коми в 1930-е годы. С. 8-14. DOI: $10.19110 / 2304-5922-2020-2-8-14$

Обедков А.П. (Сыктывкар). Средние города в системе расселения населения России. С. 15-24. DOI: $10.19110 / 2304-5922-2020-2-15-24$

Алексеева Л.В. (Нижневартовск). Формирование населения города Нижневартовска (середина 1960-х начало 1990-х годов). С. 25-29.

DOI: $10.19110 / 2304-5922-2020-2-25-29$

Обедков А.П. (Сыктывкар). Вековая динамика численности и источников формирования населения Республики Коми в 1920-2020 годах: этапы и типы демографического развития. С. 30-38.

DOI: $10.19110 / 2304-5922-2020-2-30-38$

\section{СОВРЕМЕННЫЕ ЭТНОДЕМОГРАФИЧЕСКИЕ ПРОЦЕССЫ}

Смирнов А.В. (Сыктывкар). Население арктических столиц: роль административных центров в демографическом развитии регионов Арктики. С. 39-45.

DOI: $10.19110 / 2304-5922-2020-2-39-45$

\section{ИСТОРИОГРАФИЯ, ИСТОЧНИКИ, МЕТОДОЛОГИЯ}

Силин В.И. (Сыктывкар). Атлас Архангельской епархии как демографический источник. С. 46-48. DOI: $10.19110 / 2304-5922-2020-2-46-48$

Куратов О.А. (Сыктывкар). Обзор делопроизводственных и статистических источников изучения миграционных процессов на территории Европейского Севера во второй половине XIX века. С. 49-51. DOI: $10.19110 / 2304-5922-2020-2-49-51$

\section{НАУЧНОЕ НАСЛЕДИЕ}

Лашук Л.П., Жеребцов Л.Н. (Сыктывкар). Материалы к этнической истории сысольских коми. (Из отчета Сысольской этнографической экспедиции Коми филиала АН СССР 1958 года). С. 52-70.

ПРАВИЛА ДЛЯ АВТОРОВ журнала «Историческая демография». С. 71-72. 


\section{ПРАВИЛА ДЛЯ АВТОРОВ журнала «Историческая демография»}

Журнал публикует научные статьи на русском и английском (с кратким, до 1 стр., резюме на русском) языках объемом, как правило, до 0,5 п.л. (до 20000 знаков, включая пробелы) и краткие сообщения объемом 0,1-0,2 п.л. (до 8000 знаков, включая пробелы) по следующим проблемам: история и современное состояние историко-демографических исследований; источники для проведения историко-демографических исследований и методика их анализа; этнодемографические процессы в древности и средневековье; общее и особенное в историко-демографическом развитии стран и регионов в новое и новейшее время; современная этнодемографическая ситуация и перспективы ее развития; историческая география; методология историкодемографических и историко-географических исследований. К публикации также принимаются рецензии на книги, информация о научных конференциях, комментарии к ранее опубликованным работам, хроника научной жизни. Решение о публикации принимается редакционной коллегией журнала после рецензирования с учетом новизны, научной значимости и актуальности представленных материалов. Статьи, отклоненные редколлегией, повторно не рассматриваются. Авторы несут ответственность за научное содержание, достоверность и оригинальность приводимых данных.

Требования, предъявляемые к оформлению текстов для публикации:

1. Материал предоставляется в электронном виде в текстовом редакторе Microsoft Word. Имя файла составляет фамилия первого автора, например: Ivanov.doc. Формат A4. Поля по 2 см; шрифт - Times New Roman; размер кегля - 10 пунктов; межстрочный интервал - одинарный. Вставка символов - Symbol. Просим не пользоваться особыми шрифтами и оригинальными символами. Текст набирается без принудительных переносов. Разрядки слов не допускаются.

2. Абзацы задаются автоматически (0,7 cм), а не с помощью пробелов. Расстановка переносов - автоматическая (в словах из прописных букв переносы не ставятся).

3. В первой строке печатается индекс УДК (выравнивание влево). Во второй строке печатаются инициалы и фамилия автора с выравниванием по центру, курсивом. Третья строка оставляется пустой. В четвертой строке печатается название статьи полужирным шрифтом, выравнивание по центру. Пятая строка остается пустой. С шестой строки печатается аннотация (не более 7 строк) на русском языке обычным шрифтом с выравниванием по ширине. После аннотации печатаются ключевые слова на русском языке (не более семи слов и словосочетаний). Далее печатаются на английском языке с соблюдением тех же требований: инициалы и фамилия автора, название статьи, аннотация, ключевые слова. После этого пропускается одна строка, далее печатается текст обычным шрифтом с выравниванием по ширине.

4. Рисунки, фотографии, схемы, таблицы, диаграммы необходимо присылать в одном дополнительном файле. Максимальное количество иллюстраций - 5. Рисунки и фотографии должны быть черно-белыми: с разрешением не ниже 300 пикс/дюйм. Рисунки и таблицы должны быть пронумерованы и иметь названия. В тексте необходима ссылка на конкретный рисунок или таблицу, например: «Рассмотрим численность населения Северного края (табл. 1)». Название таблицы располагается над ней и оформляется следующим образом:

Таблийа 1

\section{Численность населения Северного края в 1939 2.}

Ссылки на источники к таблице даются под ней (не в сноске) курсивом, например: «Источники: ГААО. Ф. 1. Оп. 2. Д. 3. Л. 4-5.».

Название рисунка и комментарий располагаются под ним, курсивом, например:

«Рис. 2. Источники роста населения Северного края.».

5. Список ссылок приводится отдельным разделом в конце статьи и оформляется в соответствии со следующими требованиями. Архивные и литературные источники располагаются в порядке их упоминания по тексту в виде нумерованного списка. Названия публикаций приводятся полностью, сокращения названий, употребление слов «Указ. соч.», «Там же» и т.п. не допускается. Ссылка на источник по тексту оформляется как число в квадратных скобках, вручную. Например: [1]. Автоматические сноски не допускаются!

6. Ссылки на неопубликованные работы допускаются только в том случае, если они переданы на хранение в государственные архивы, научные архивы учреждений, например: Сидоров С.С. Очерки демографической истории вымичей // Научный архив Коми НЦ УрО РАН. Ф. 1. Оп. 2. Д. 3.45 л.

7. Примечания, пояснения к тексту, касающиеся использованных терминов, имен, географических названий и т.п. даются в постраничных сносках под «звездочкой» (*). 
8. Если есть сокращения, прилагают список с расшифровкой, например:

МАЭ ОмГУ - Музей археологии и этнографии Омского государственного университета им. Ф.М. Достоевского.

9. В конце статьи указывается фамилия, имя, отечество автора (авторов) полностью, город (населенный пункт), ученая степень, должность, место работы (без сокращений), служебный адрес, адрес электронной почты, например: Иванов Иван Иванович (Сыктывкар) - доктор исторических наук, заведующий кафедрой этнографии Сыктывкарского государственного университета, 167982, г. Сыктывкар, Ленинский проспект, 222, ivanov@mail.ru; Петров Петр Петрович (Новосибирск) - кандидат исторических наук, старший научный сотрудник сектора демографии Института истории Сибирского отделения РАН, 000000, г. Новосибирск, ул. Академическая, 333, ppp21@bk.ru.

Образец оформления:

УДК

\section{И.И. Иванов}

Проблемь демографии.....

\section{Демография}

Ключевые слова: демография, численность населения, мигращии...

\section{I.I. Ivanov}

\section{Demography}

Problems...

Key words: demography, ...

Ааааааааааа ббббббббббббббб вввввввввввввв ггггггггггггггггг [1]. Ддддддддддд eeeeeeeeee жжжжжжжжжжж [2].

\section{Источники и литература}

1. Иванов И.И., Петрова И.Н. Демографическая политика // Социологические исследования. 2006. C. $15-16$.

2. Сидоров В.В. Демография. М.: Дело, 2006. С. 75. (или: 557 с.).

3. О милиции: федеральный закон от 15.12.2005 № 152-Ф3 // Собр. законодательства РФ. 2005. Ст. 575.

4. Волков П. О войне // Красное знамя. 1990. 16 авг.

5. Национальный архив Республики Коми (далее - НАРК). Ф. 1. Оп. 2. Д. 3. Л. 4.

6. Фенухин В.И. Этнополитические конфликты в современной России: на примере Северо-Кавказского региона: Автореф. дис. ... канд. полит. наук. М., 2002. С. 14.

7. Полевые материалы диалектологических и этнолингвистических экспедиций Ростовского государствен ного университета (далее - ПМДЭЭ РГУ). Информатор И.Р. Пшеничнова, 1926 г.р., записана в станице Елизаветинской Азовского района Ростовской области в июле 2003 г.

8. Кремлева С.О. Сетевые сообщества. URL: http:// www.library.by/portalus/modules/psychology (дата обращения: 11.11.2005).

Редколлегия оставляет за собой право отклонять материалы, не соответствующие указанной тематике или предъявляемым требованиям к оформлению.

Материалы, опубликованные в журнале «Историческая демография», размещены в РИНЦ, а также на сайте ИЯЛИ Коми НЦ УрО РАН: http://illhkomisc.ru/library/nauchnye-zhurnaly 


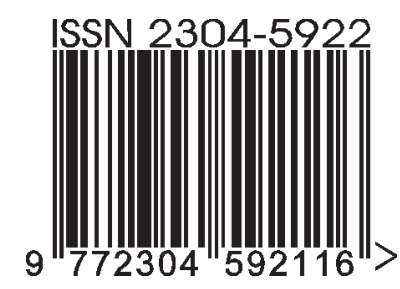

Научный журнал

\section{ИСТОРИЧЕСКАЯ ДЕМОГРАФИЯ}

2021. № 1 (27).

Технический редактор Н.К. Забоева

Оригинал-макет - Н.К. Забоева

Компьютерный набор. Формат 60 x $84{ }^{1} / 8$.

Подписано в печать 17.05.2021.

Уч.-изд. л. 7,3. Тираж 300 экз.

Информационно-издательский отдел Института языка, литературы и истории Коми НЦ УрО Российской АН. 167982, ГСП-2, г. Сыктывкар, ул. Коммунистическая, 26. 
